ELISABETH NASCIMENTO SILVA

GERENCIAMENTO DO SUPRIMENTO NOS EMPREENDIMENTOS HOTELEIROS

São Paulo

2008 

HOTELEIROS

Dissertação apresentada à Escola Politécnica da Universidade de São Paulo para obtenção do título de Mestre em Engenharia.

Área de Concentração: Engenharia de Construção Civil e Urbana

GEPE-RES: Real estate

Orientador: Prof. Dr. Claudio Tavares de Alencar 


\section{GERENCIAMENTO DO SUPRIMENTO NOS EMPREENDIMENTOS HOTELEIROS}

Dissertação apresentada à Escola Politécnica da Universidade de São Paulo para obtenção do título de Mestre em Engenharia.

Área de Concentração: Engenharia de Construção Civil e Urbana

GEPE-RES: Real estate

Orientador: Prof. Dr. Claudio Tavares de Alencar

São Paulo 
Este exemplar foi revisado e alterado em relação à versão original, sob responsabilidade única do autor e com anuência de seu orientador.

São Paulo, 03 de Novembro de 2008.

Assinatura do autor

Assinatura do orientador

FICHA CATALOGRÁFICA

Silva, Elisabeth Nascimento

Gerenciamento do Suprimento nos Empreendimentos Hoteleiros / Elisabeth Nascimento Silva. - São Paulo, 2008.

145 páginas

Dissertação (Mestrado) - Escola Politécnica da Universidade de São Paulo. Departamento de Engenharia de Construção Civil e Urbana.

1. Empreendimentos Imobiliários (Planejamento) 2. Hotéis 3. Construção Civil 4. Logística (Administração de Materiais). Universidade de São Paulo. Escola Politécnica. Departamento de Engenharia de Construção Civil e Urbana II. t. 
Aos meus pais, Antônio José e Maria das Graças, e a minha irmã, Elisângela. Sem vocês na minha vida nunca conseguiria essa conquista. 


\section{AGRADECIMENTOS}

Primeiramente tenho que agradecer a Deus pela força que me deu ao longo dos anos de desenvolvimento dessa pesquisa. E aos meus pais e minha irmã pelo apoio incondicional.

Ao Prof. Claudio pela preciosa orientação na conclusão desse trabalho e pelo aprendizado nas disciplinas.

Ao Prof. Sérgio pelas preciosas horas de orientação e paciência quanto aos meus intensos questionamentos em relação aos temas dessa dissertação. Você é um exemplo de profissional a ser seguido.

Ao Prof. Jorge Lima, que incentivou a estudar desde a graduação em Sergipe. Sem o seu incentivo nunca teria chegado a São Paulo.

Aos Professores Eliane Monetti e Rocha Lima pela oportunidade aprendizado nas suas disciplinas.

Ao Asmussen, pela orientação em relação às questões dos empreendimentos hoteleiros.

Não posso deixar de falar das minhas tias queridas que tanto torcem por mim e meus tios que sempre me deram força para continuar aqui estudando. E aos meus primos e primas que cada vez que cheguei em casa me deram força para continuar. Muito obrigada por torcerem por essa conquista.

Um dos grandes aprendizados durante a elaboração desse trabalho foi a força da amizade. Vários amigos me deram ajudaram ao longo desses anos. Amigos que já conhecia de longa data e amigos que conquistei ao longo dessa pesquisa. E até amigos que hoje posso dizer que são da minha família.

Agradeço à Marquinhos, Luciana e Igor pelo companheirismo, tanto nas horas boas como nas horas em que precisei de um ombro. Vocês sempre estenderam a mão para me ajudar.

Aos amigos Renoir, Rezende, Luiz Claudio e Marco Antônio, abrigada pela companhia ao longo desses anos de São Paulo. 
Aos meus grandes amigos de faculdade que mesmo distante sei que torceram por mim Erika, Viviane, e também Elaine, nesse último ano aqui em Sampa me ajudou a ter forças para acabar a pesquisa.

Aos meus amigos do colégio, quanto tempo a gente se conhece e vocês permanecem na minha vida Janaína, André, Juliana e Marla. Adoro vocês!

Aos meus amigos da Asteroide e das disciplinas, em especial a Carolina, pois nossas madrugadas de estudo ajudaram muito na conclusão dessa pesquisa.

A todos, que por ventura esqueci nomear, mas sei que sempre torceram por mim. 


\section{RESUMO}

O cenário do ciclo de implantação de hotéis apresenta características diferenciadas em relação aos demais empreendimentos de real estate. Dentre essas, se destaca a presença de diversos stakeholders capazes de influenciar de forma direta na configuração do empreendimento. Outra característica é a forte concentração dos processos de suprimento, em particular no final de sua fase de implantação, devido à necessidade de disponibilizar os insumos específicos dessa tipologia de empreendimento, necessários a sua entrada em operação. Esse cenário diferenciado traz ao sistema de gerenciamento de suprimentos do empreendimento demandas não usuais em outros tipos de empreendimentos de real estate, tais como: [1] um acurado processo de controle da baseline do empreendimento, [2] um abrangente processo de controle de escopo dos diversos fornecedores envolvidos, [3] necessidade de uma estreita coordenação da logística de implantação e operacionalização do empreendimento, em particular na área de suprimento. Nesse cenário, o objetivo da dissertação é apresentar diretrizes para os processos de gerenciamento da logística na implantação de hotéis, como parte integrante dos processos do gerenciamento do empreendimento, com foco naqueles aspectos que diferenciam os hotéis dos demais empreendimentos de real estate. O trabalho descreve os resultados dos levantamentos de campo sobre o escopo da implantação de hotéis, com a finalidade de identificar as necessidades desse ciclo. Estes dados, juntamente com uma análise dos processos de gerenciamento de suprimentos versus os requisitos de implantação já mencionados, permitiram estruturar diretrizes para ao gerenciamento dos processos logísticos diante das características da implantação de hotéis. A conclusão desse trabalho é a necessidade de recorrer a processos, que embora típicos do gerenciamento de empreendimentos, não são usuais na área de Gestão de Suprimentos, tais como: (1) processos de controle de escopo, (2) controle de configuração (de escopo e da baseline) e (3) controle de interfaces, aplicados em particular para a gestão da logística envolvida na implantação e operacionalização de hotéis. 


\begin{abstract}
The cycle of implantation of hotels is different among others real estate enterprises. There are many stakeholders capable to influence directly in the configuration of the hotel. Another characteristic is the strong concentration of the procurement processes, most in the end of the phase of implantation, due to necessity of the cycle of operation. This differentiated scene brings to the procurement management not usual demands in others real estate enterprises, such as: [1] a strong control of baseline, 2] an strong control process with involved suppliers, 3] necessity to see the needs of operation cycle during de implantation cycle. The objective of the research is to propose guidelines for the processes of the logistic in the implantation of hotels, as an integrant of the processes of management of the enterprise, with focus in those aspects that differentiate the hotels of others real estate enterprises. The research describes the results of the field surveys on the target of the implantation of hotels, with the purpose to identify the necessities of this cycle. These data, together with an analysis of the processes of procurement management versus the requirements of implantation, allowed structuralizing the guidelines for the logistic process. The conclusion of this research is the necessity to appeal the processes, that even so typical of the management of enterprises, are not usual in the area of procurement management, such as: (1) processes of scope control, (2) configuration control (baseline) and (3) control of interfaces, applied in particular for the logistic management of involved in the implantation and the of hotels operation.
\end{abstract}




\section{SUMÁRIO}

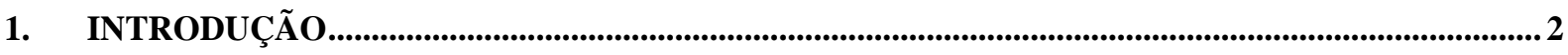

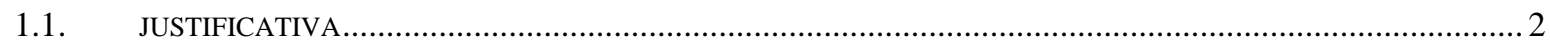

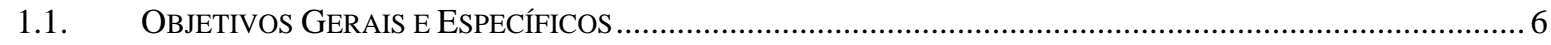

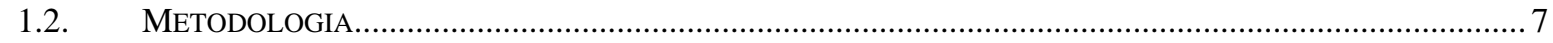

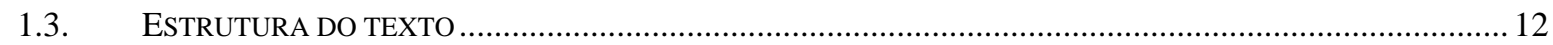

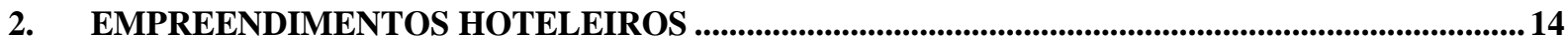

2.1. CARACTERÍSTICAS DO NEGÓCIO HOTELEIRO ……………............................................................... 16

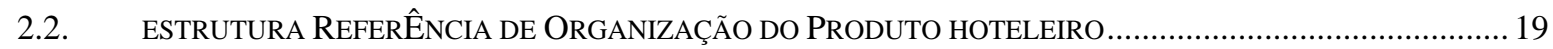

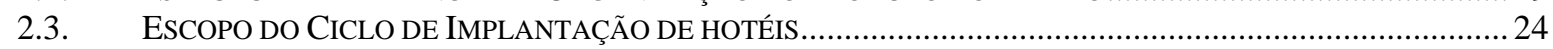

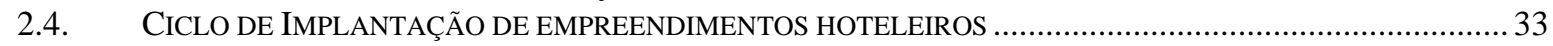

3. A GESTÃO DA LOGÍSTICA COMO SUPORTE AOS PROCESSOS DO GERENCIAMENTO DE

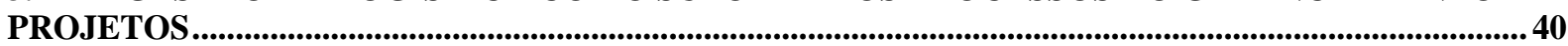

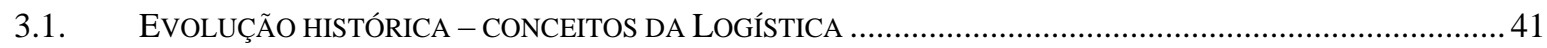

3.2. GESTÃo DA LOGÍstiCA INTEGRADA AOS PROCESSOS DO GERENCIAMENTO DE PROJETOS ................... 54

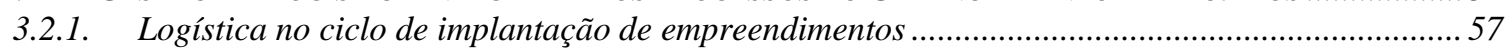

4. DEFINIÇÃO DA LOGÍSTICA NA IMPLANTAÇÃO DE HOTÉIS ...................................................80

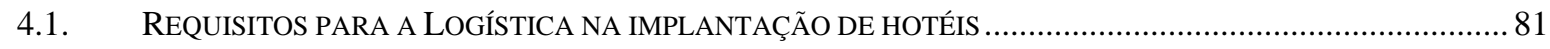

4.2. PARTICULARIZAÇÃO DOS PROCESSOS LOGÍ́STICOS NA IMPLANTAÇÃO DE HOTÉIS ................................... 84

5. PROCESSOS LOGÍSTICOS NA IMPLANTAÇÃO DE HOTÉIS..........................................................89

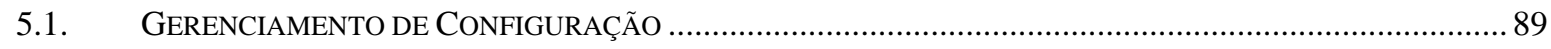

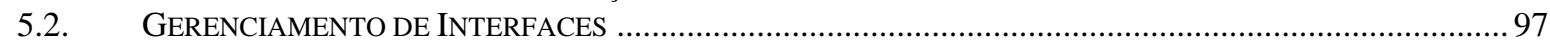

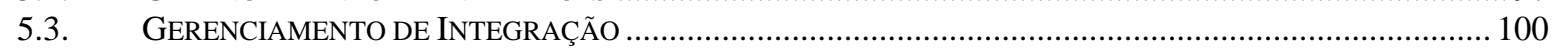

5.4. SÍNTESE DOS PROCESSOS LOGÍSTICOS NO CICLO DE IMPLANTAÇÃO DE HOTÉIS ……………................ 104

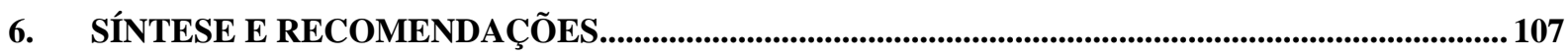

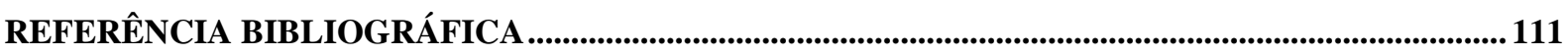

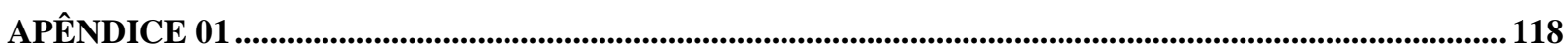

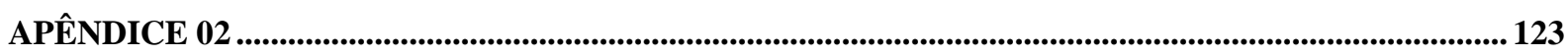

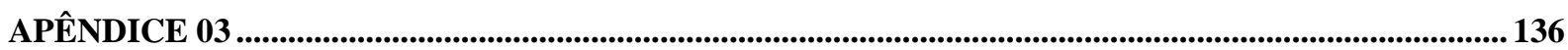




\section{lista de Figuras}

Figura 1 - Ciclos dos empreendimentos de base imobiliária ...................................................

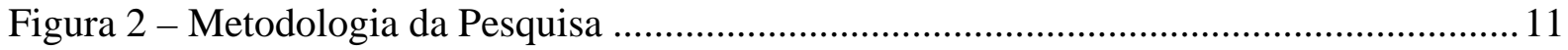

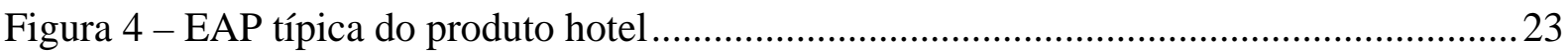

Figura 5 - Hipótese do escopo da implantação de hotéis......................................................... 26

Figura 6 - Identificação dos itens específicos de hotéis........................................................29

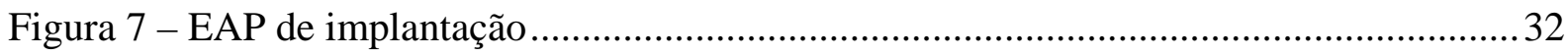

Figura 8 - Evolução do Conceito Logístico ........................................................................... 42

Figura 9 - Evolução da Estrutura de Gerenciamento da Gestão da Logística .........................50

Figura 10 - Canais de distribuição - direto e reverso ..............................................................52

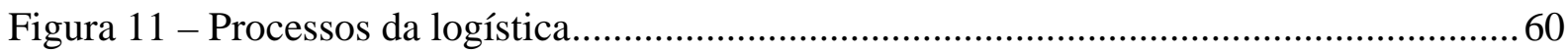

Figura 12 - Processo de programação por recursos ............................................................64

Figura 13 - Requisitos da implantação de hotéis para a logística versus processos gerenciais que integrados a logística atendem as necessidades do empreendimento ............................... 87

Figura 14 - Estruturação dos processos logísticos na implantação de hotéis ......................... 105

Figura 15 - Características Físicas de Hotéis Centrais ......................................................... 127

Figura 16 - Características Físicas de Hotéis Não-Central................................................. 130

Figura 17 - Características Físicas de Resort ..................................................................... 132

Figura 18 - Características Físicas do Hotel Econômico..........................................................134

Figura 19 - Hipótese do escopo da implantação de hotéis................................................... 140

Figura 20 - Tabulação das Entrevistas do Estudo de Caso ................................................. 144 


\section{INTRODUÇÃO}

O objetivo da pesquisa é estruturar diretrizes para os processos da gestão da logística integrados aos processos do gerenciamento do ciclo de implantação de empreendimentos hoteleiros, com foco naqueles aspectos que diferenciam este tipo de empreendimento de outros empreendimentos de natureza imobiliária, como aqueles destinados à moradia.

A partir da análise dos processos e atividades do ciclo de implantação de hotéis foi possível identificar certa complexidade em relação à multiplicidade de insumos, ou seja, este ciclo além de abranger o fornecimento e instalação ou aplicação de insumos ${ }^{1}$ característicos à qualquer empreendimento de real estate, em particular aqueles de natureza residencial, também contempla uma extensa gama de insumos adicionais próprios dessa tipologia de negócio. Além disso, estes insumos necessários para a operacionalização do hotel, são instalados em um curto espaço de tempo ao final do ciclo de implantação.

A necessidade de se gerenciar fluxos complexos de insumos, para a operacionalização de empreendimentos hoteleiros, leva à avaliação quanto ao emprego de processos gerenciais capazes de lidar com esse cenário.

Esse capítulo tem o objetivo de apresentar a justificativa da pesquisa, os objetivos gerais e específicos, bem como a metodologia de trabalho empregada.

\subsection{JUSTIFICATIVA}

O setor hoteleiro nacional possui um patrimônio de $\mathrm{R} \$ 78,7$ bilhões e gasta em média $\mathrm{R} \$ 2$ bilhões por ano com mão de obra e mais de R\$ 30 milhões com Contribuição para Financiamento da Securidade Social (Cofins) (ABIH, 2008).

O setor de turismo possui a expectativa de inserção do Brasil na rota do turismo internacional. No Oriente Médio o crescimento de turistas internacionais em 2007 em relação à 2006 foi 13\%, na África 8\%, no Continente Americano 5\% e no Brasil 1,2\% (CAMPASSI; VALENTTI, 2008). Isso indica que no cenário mundial de crescimento turístico, o Brasil

\footnotetext{
${ }^{1}$ Quando se fala em insumos nesse texto, referem-se a materiais, equipamentos e serviços necessários na implantação do empreendimento
} 
possui capacidade de desenvolvimento devido às suas riquezas naturais e diversidade cultural, características que atraem tanto turista dos EUA quanto da Europa.

Essa expectativa de crescimento do turismo brasileiro pode ser transferida para o setor hoteleiro, pois o crescimento do turismo é influenciado diretamente pela capacidade de hospedagem dos hotéis da região em potencial.

Hotel, aqui entendido como um empreendimento de base imobiliária, apresenta um ciclo de vida que pode ser desdobrado em ciclos de formatação, implantação, operação e exaustão (ROCHA LIMA, 1994). O ciclo de formatação envolve a caracterização do produto, estudos econômicos e financeiros e elaboração de diretrizes estratégicas para a implantação. No ciclo de implantação, ocorre a construção da edificação e instalação dos itens necessários para a operação. Além disso, o ciclo de implantação inclui a fase de partida e colocação em operação, como resultado tem-se o empreendimento pronto para operar. Os recursos financeiros aplicados permanecem imobilizados ${ }^{2}$ ao longo desses dois ciclos.

No ciclo de operação ocorre a exploração do empreendimento, que resulta nos retornos de recursos financeiros aplicados anteriormente. O último ciclo é o ciclo de exaustão, onde inicialmente ocorrem investimentos para a reciclagem do empreendimento, para que o empreendimento possa continuar a proporcionar resultados similares ao ciclo anterior (ciclo de operação).

A Figura 1 ilustra os ciclos de um empreendimento de base imobiliária.

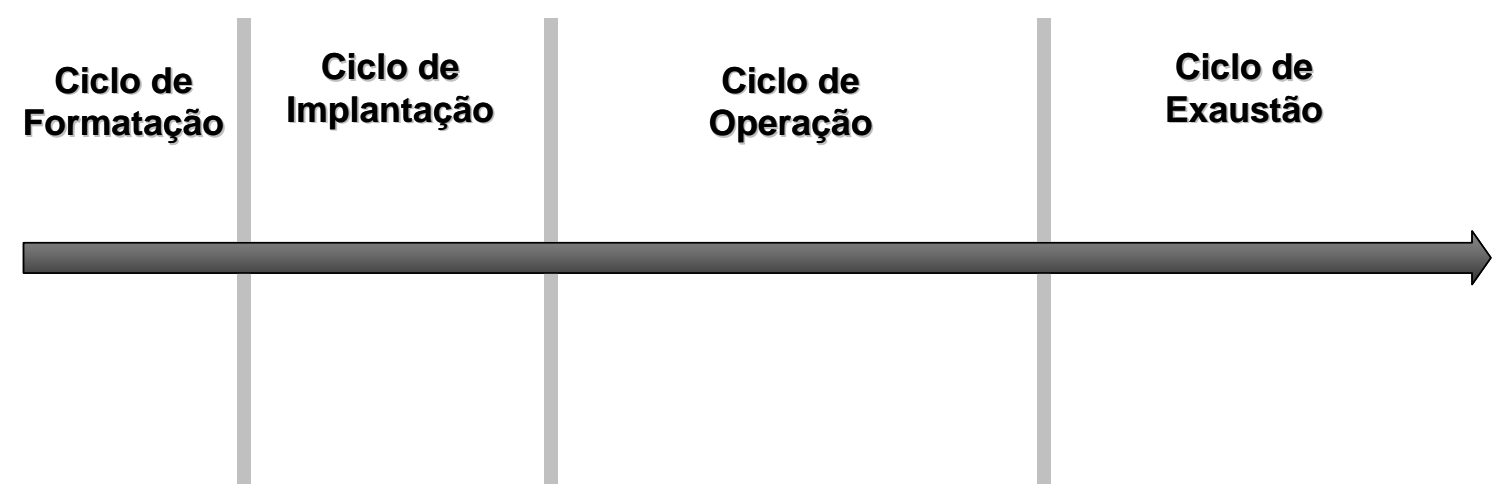

Figura 1 - Ciclos dos empreendimentos de base imobiliária

(Fonte: Modificado de Rocha Lima; 1994)

\footnotetext{
${ }^{2}$ Considera-se que os recursos financeiros permanecem imobilizados devido à baixa liquidez ao longo dos ciclos e formatação e implantação.
} 
Segundo estudos realizados no Brasil e no exterior, a competitividade do empreendimento de base imobiliária, como os hotéis, pode progredir em função do período de lançamento, com o aumento substancial da rentabilidade, e, esse período pode ser conhecido devido à tendência de comportamento cíclico da inserção de um novo produto no mercado (ASMUSSEN, 2004; MATTOS, 2004; WEATON; ROSSOFF, 1998; CANTER; MAHER, 1998).

Desta forma, atender aos objetivos de prazo, estabelecidos na fase de planejamento é fator crítico na implantação de empreendimentos hoteleiros. A implantação de hotéis engloba, além de todas as atividades de execução de uma edificação, o fornecimento e instalação dos equipamentos e mobiliários necessários para a operação do mesmo. Esses insumos de operacionalização são instalados ao final do ciclo de implantação ${ }^{3}$.

Os empreendimentos hoteleiros, cada vez mais, apresentam uma estrutura física diversificada com a finalidade de atender as necessidades de seus clientes. Os hotéis devem proporcionar apartamentos confortáveis, bem dimensionados, devidamente equipados e com ambientes agradáveis. As atividades administrativas, industriais (produção de alimentos, lavanderia), comerciais (restaurantes e lojas), centrais de sistemas de facilidades (água fria e quente, vapor, energia, ar condicionado), de manutenção, além de outras atividades relacionadas à realização de eventos com recreação e lazer também fazem parte dos serviços oferecidos pelos empreendimentos hoteleiros (ANDRADE, 2002).

A implantação dessa estrutura hoteleira engloba a aquisição de uma multiplicidade e diversidade de insumos. E além disso, os insumos adquiridos durante a fase de implantação também devem estar disponíveis para a manutenção do empreendimento no ciclo de operação. Ou seja, as aquisições de determinados insumos durante o ciclo de implantação devem consideraras condições de operação.

A natureza desse tipo de negócio, por um lado exige imobilização de recursos financeiros significativos, e por outro lado, apresenta sazonalidades de ocupação capazes de afetar expressivamente os resultados do negócio. Além disso, cada vez mais os empreendimentos são implantados com estruturas diversificadas devido à necessidade de atender as exigências impostas pela formatação do empreendimento.

\footnotetext{
${ }^{3}$ As características da implantação de hotéis que exigem processos gerenciais específicos serão detalhadas no Capítulo 2.
} 
Diante do exposto sobre a rigidez de prazo em um cenário de implantação com diversidade e multiplicidade de insumos, a inserção de processos gerenciais que auxiliem o gerenciamento da implantação do empreendimento mostra-se necessária, por exemplo, a inserção de processos orientados ao gerenciamento de projetos.

O gerenciamento do suprimento no ciclo de implantação de hotéis possui um maior volume de atividades que a implantação dos demais empreendimentos de real estate devido ao fornecimento e instalação de insumos específicos para a operacionalização do empreendimento.

Dessa forma, o gerenciamento do suprimento na implantação de hotéis possui características não usuais aos demais empreendimentos de real estate devido à execução de atividades adicionais em um curto espaço de tempo ao final do ciclo de implantação. A execução dessas atividades características dos empreendimentos hoteleiros produz a necessidade de processos gerenciais adicionais aos processos característicos do gerenciamento de suprimentos.

A ênfase em processos de gerenciamento com foco no fluxo de insumos, especialmente no gerenciamento dos insumos característicos da implantação de hotéis, pode colaborar de modo significativo para o cumprimento dos prazos, escopo e qualidade exigidos para o empreendimento.

Os processos da logística estudam como melhorar o desempenho esperado na implantação do projeto com o planejamento, organização e controle efetivo das atividades relacionadas com fluxos dos insumos na realização das tarefas (BALLOU, 1993).

Caron e Fiore (1995) integraram a logística ao gerenciamento de projetos com a finalidade de evitar atrasos e aumento dos custos do projeto. Enquanto Yeo e Ning (2002) integraram o gerenciamento de projetos ao gerenciamento da cadeia de suprimento com a finalidade de evitar atrasos e aumento dos custos. Já Caron, Marchet e Perego (1998) integraram o gerenciamento do suprimento com a logística, com o objetivo de evitar interrupções no projeto devido à falta de insumo e, por decorrência, atrasos na finalização do projeto. É possível constatar que vários estudos integraram aos processos do gerenciamento de projeto os processos logísticos com o objetivo de atender às exigências ao prazo, escopo, custo e qualidade do projeto. 
A logística, quando bem estruturada, agrega eficiência no processo de suprir o empreendimento, devido à sua capacidade de programar, organizar e controlar o fluxo de insumos e informações correspondentes.

Os processos da gestão da logística são inseridos no cenário do gerenciamento de projetos, mais precisamente no cenário dos processos do gerenciamento de suprimento, com o objetivo de melhorar a capacidade de gerenciar o fluxo dos insumos característicos aos hotéis. Esses processos buscam atender exigências de prazo e escopo impostas pela formatação do empreendimento.

\subsection{OBJETIVOS GERAIS E ESPECÍFICOS}

Diante do exposto sobre as condições do ciclo de implantação de hotéis o objetivo geral da pesquisa é identificar, analisar e recomendar diretrizes para a gestão dos processos logísticos integrados ao gerenciamento de projetos no ciclo de implantação de empreendimento hoteleiros. A pesquisa visa estruturar a gestão do processo logístico integrado aos processos do gerenciamento de projetos, a partir da premissa que a utilização de processos estruturados e padronizados produz melhores resultados na implantação de empreendimentos hoteleiros.

Os objetivos específicos da pesquisa são:

Identificar quais características do ciclo de implantação dos hotéis influenciam processos logísticos, com foco nas características que diferenciam os hotéis dos demais empreendimentos de real estate;

Identificar e analisar os processos da gestão da logística;

Identificar os requisitos dos processos da gestão da logística no ciclo de implantação de hotéis;

Identificar, analisar e recomendar processos complementares que adeqúem a estruturação da integração da gestão da logística aos processos do gerenciamento de projetos no ciclo de implantação de hotéis. 


\subsection{METODOLOGIA}

Com a finalidade de atingir os objetivos da pesquisa a seguinte metodologia foi elaborada.

I. Identificação e análise do ciclo de implantação dos empreendimentos hoteleiros a partir de levantamentos bibliográficos, levantamento de campo e estudo de caso;

II. Identificação e análise dos processos logísticos como suporte aos processos do gerenciamento de projetos na implantação de empreendimentos;

III. Identificação dos requisitos de suprimento no ciclo de implantação dos empreendimentos hoteleiros;

IV. Análise dos processos da gestão da logística no cenário dos requisitos do ciclo de implantação de hotel;

V. Identificação das diretrizes recomendadas para os processos da gestão da logística no ciclo de implantação de hotéis.

$\underline{\text { Identificação e análise do ciclo de implantação de empreendimentos hoteleiros }}$

A identificação e análise do ciclo de implantação de hotéis envolveram a elaboração de um corpo de conhecimento sobre as atividades e processos necessários para colocar o empreendimento hoteleiro pronto para operar.

Esse corpo de conhecimento buscou identificar as características do negócio e dos processos de implantação que influenciam na gestão de suprimento durante a implantação do empreendimento, a partir de levantamentos bibliográficos, e quando esses levantamentos não foram suficientes, o levantamento de campo e estudo de caso foram realizados.

Os levantamentos bibliográficos sobre essas características foram realizados com embasamento nas publicações no Núcleo de Real Estate do departamento de Construção Civil da Escola Politécnica da USP, teses, dissertações, livros, artigos acadêmicos (fonte: Real Estate: Economia e Mercados, Lodging Hospitality, Cornell Hotel and Restaurant 
Administration Quartely), publicações de organizações referencia no setor hoteleiro brasileiro (ABIH - Associação Brasileira da Indústria da Hotelaria, FOHB - Fórum dos Operadores Hoteleiros do Brasil) e rede mundial de computadores (www.arcoweb.com.br).

Além do levantamento bibliográfico, houve um levantamento de campo nos sítios oficiais das operadoras de hotéis através da rede mundial de computadores, para a identificação de padrões na organização ${ }^{4}$ dos serviços e respectiva infra-estrutura oferecidos pelos empreendimentos hoteleiros administrados por operadoras no Brasil. A partir da identificação de um padrão de organização, juntamente com o conhecimento sobre a o gerenciamento da implantação de empreendimentos, houve a elaboração de uma hipótese para o escopo de implantação de hotéis. Essa hipótese foi consolidada a partir de um estudo de caso com profissionais que atuam no mercado de implantação de hotéis.

Houve a necessidade de recorrer aos referenciais teóricos específicos do gerenciamento de empreendimentos tanto para o mapeamento da tendência de estrutura padrão, como para o mapeamento do escopo de implantação. A principal ferramenta empregada no mapeamento de escopo foi a elaboração de uma EAP (Estrutura Analítica de Projeto) referencial.

Uma EAP compreende "uma decomposição hierárquica orientada à entrega do trabalho a ser executado pelo time ${ }^{5}$ do projeto, para atingir os objetivos do projeto e criar as entregas necessárias” (PMI, 2004, p.363). Já Cleland e King (1983) definem EAP como uma orientação do produto dividido em árvores de famílias que organiza, define e ilustra graficamente o produto a ser implantado, como também o trabalho a ser realizado para atender as especificações do mesmo. Uma EAP permite identificar hierarquicamente os pacotes de trabalho e produtos de um projeto para obter os resultados almejados.

A identificação do escopo de implantação de um hotel ${ }^{6}$ abrangeu, de um lado, o conjunto componente de sistemas e subsistemas correlato às edificações residenciais e, de outro lado, aquele que caracteriza os trabalhos de partida e colocação em operação de um hotel. Ou seja, foram identificados os pacotes de trabalho relacionados à edificação, comum a qualquer

\footnotetext{
${ }^{4}$ Padrão de organização refere-se ao conjunto de ambientes como quartos, recepção, cozinha, dentre outros que compõem a estrutura de um empreendimento hoteleiro.

${ }^{5}$ Um time refere-se ao conjunto de pessoas que possuem responsabilidades atribuídas para a finalização do projeto (PMI, 2004).

${ }^{6}$ A partir desse momento, quando no texto escreve-se escopo da implantação de um hotel refere-se aos hotéis que possuem a organização padrão identificada nesse trabalho.
} 
empreendimento residencial de real estate, e os pacotes de trabalho relacionados especificamente à operacionalização de hotéis.

Nesse momento da pesquisa foi possível identificar quais pacotes de trabalho seriam analisados e recomendadas diretrizes para a gestão do suprimento, já que a pesquisa se concentra na gestão de suprimento dos pacotes de trabalho específicos da implantação de hotéis, que são carentes de estudos acadêmicos.

Identificação e análise dos processos logísticos como suporte aos processos do gerenciamento de projetos na implantação de empreendimentos

A identificação e análise dos processos logísticos ocorreram a partir de um levantamento bibliográfico embasado nas publicações, teses, dissertações, livros e artigos acadêmicos (fontes: International Journal of Project Management, Journal of Marketing, Management Research News, Project Management Journal, Real Estate Economics). Esse levantamento permitiu estruturar um referencial teórico quanto aos processos da logística como suporte ao gerenciamento de projetos. Esses processos podem ser aplicados a qualquer empreendimento de real estate.

$\underline{\text { Identificação dos requisitos da gestão de suprimento no ciclo de implantação dos }}$ empreendimentos hoteleiros

A partir da identificação dos pacotes de trabalho do ciclo de implantação foi possível reconhecer quais características influenciam nos processos de suprimento, e com isso, identificar os requisitos gerenciais a serem atendidos por processos de gestão de suprimento, em particular, os processos da gestão da logística na implantação de empreendimentos. 
Análise dos processos da gestão da logística no cenário dos requisitos de hotel

Nessa etapa da pesquisa houve uma análise critica quanto aplicabilidade dos processos logísticos na gestão do fluxo dos insumos característicos à operacionalização dos hotéis. Houve constatações quanto à necessidade de processos adicionais para atender aos requisitos específicos à implantação de hotéis. Nessa etapa ocorreu a análise e recomendação da inserção de processos não usuais ao conjunto de processos da logística.

Identificação das diretrizes recomendadas para os processos logísticos no ciclo de implantação de hotéis

Nessa etapa, os processos adicionais aos usuais da logística foram estruturados a partir dos requisitos da implantação de hotéis. Foram descritas em detalhes as atividades de cada um dos processos adicionais e, em seguida, como esses processos e suas atividades estão dispostos para atender as exigências do cenário da implantação de hotéis.

Essas etapas permitiram a recomendação da inserção de processos não usuais à gestão de suprimento, como foco na gestão do fluxo de insumos, para atender às necessidades específicas do ciclo de implantação de hotéis. Além da recomendação, houve estruturação desses processos no cenário de gerenciamento da implantação. 


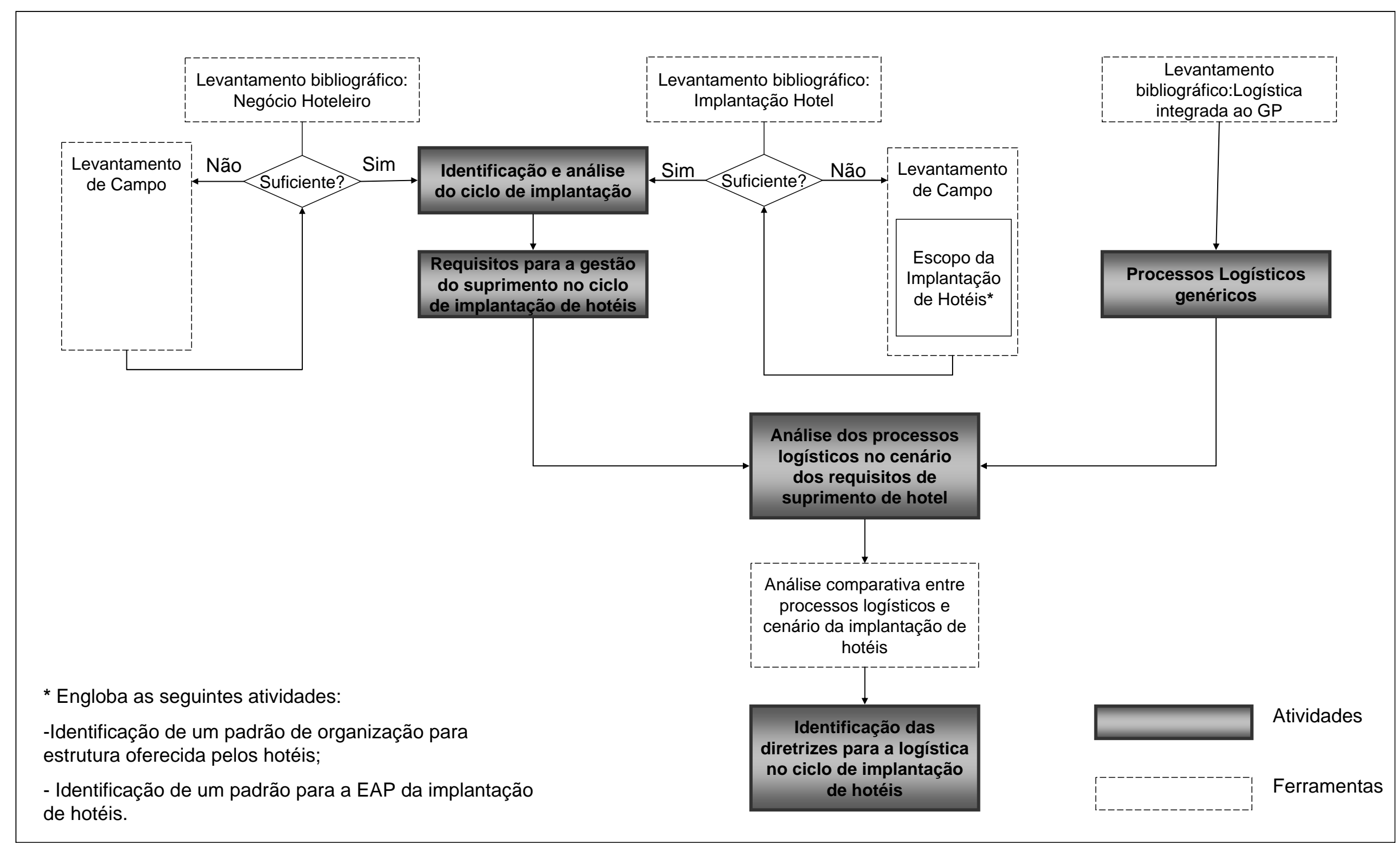

Figura 2 - Metodologia da Pesquisa

Fonte: Desenvolvido pela autora (2008) 


\subsection{ESTRUTURA DO TEXTO}

A dissertação está estruturada da seguinte forma.

\section{Capitulo 1 - Introdução}

Apresentação do tema da pesquisa, com as justificativas, objetivos gerais e específicos, metodologia e estrutura do texto.

\section{Capitulo 2 - Empreendimentos Hoteleiros}

Nesse capitulo foram identificados e analisados os pacotes de trabalho característicos ao ciclo de implantação de hotéis. Para isso houve a análise do negócio hoteleiro e do escopo do seu ciclo de implantação.

Capitulo 3 - A Gestão da Logística como Suporte aos Processos do Gerenciamento de $\underline{\text { Projetos }}$

Nesse capitulo são apresentados os resultados do levantamento bibliográfico sobre a gestão dos processos logísticos integrados ao gerenciamento de projetos. Esse capítulo é aborda conceitos da logística, bem como seus processos de gestão.

\section{Capitulo 4 - Definição da Logística na Implantação de Hotéis}

Nesse capítulo é redigida uma análise ou reflexão quanto aos requisitos da logística na implantação de hotéis. Na seqüência, ocorre a análise dos processos logísticos genéricos no cenário do ciclo de implantação de hotéis, como também, análises e recomendações de processos adicionais que atendem as necessidades da implantação do hotel.

\section{Capitulo 5 - Processos logístico na implantação de hotéis}

Nesse capitulo ocorre a estruturação dos processos logísticos com a inserção dos processos adicionais para atender aos requisitos do ciclo de implantação de hotéis. Para isso os processos adicionais são descritos detalhadamente, e na seqüência, é descrita a integração desses processos aos processos usuais da logística. 


\section{Capitulo 6 - Considerações Finais}

Esse capitulo é composto pela apresentação das principais considerações sobre o trabalho, os objetivos alcançados, as contribuições da pesquisa realizada e a proposição para trabalhos futuros a partir dos resultados encontrados. 


\section{EMPREENDIMENTOS HOTELEIROS}

Hotel é um empreendimento de base imobiliária cujo objetivo é prover a hospedagem temporária e atendimento de necessidades dos seus usuários. Um hotel deve possuir sistemas que atendam os desejos e necessidades dos hóspedes, por exemplos, apartamentos confortáveis, disponibilidade de lazer e suportar as atividades de trabalho dos seus hóspedes (ABIH, 2006).

O empreendimento hoteleiro é um provedor de serviços de hospedagem. Esse é composto pela infra-estrutura e equipe necessária para atender as necessidades dos seus hóspedes enquanto eles estiverem hospedados no empreendimento.

Esse capítulo tem como objetivo identificar os aspectos de escopo do ciclo de implantação dos empreendimentos hoteleiros que o diferenciam de outros empreendimentos de real estate, por exemplo, empreendimentos residenciais. As análises desse capítulo são no sentido de identificar os pacotes de trabalho específicos para a operacionalização dos hotéis.

A natureza dos negócios hoteleiros, tratando dos serviços de hospedagem temporária, leva seus produtos de real estate a apresentarem semelhanças com outros produtos, em particular os edifícios residenciais, sejam eles formatados como edificações residenciais verticais isoladas ou em condomínios, ou condomínios residenciais horizontais.

A questão a ser isolada neste trabalho é identificar qual o conjunto de processos de gestão de suprimentos, em particular de logística, que sejam específicos da implantação e colocação em operação de negócios hoteleiros. Parte-se, portanto, da premissa que os processos de gestão de suprimentos associados aos edifícios residenciais já apresentam maturidade suficiente para que este trabalho se concentre nos aspectos específicos e diferenciadores associados aos hotéis.

Pesquisas como Silva (2000) e Villagárcia Zegarra (2000) do Departamento de Construção Civil da Escola Politécnica da USP abordam a logística durante o ciclo de implantação de edifícios. Como também Haga (2000) aborda a integração da cadeia de suprimento e Isatto (1996) aborda a relação entre o fornecedor e as construtoras de edifícios. 
Para que se possa conduzir uma análise sistêmica sobre os aspectos de logística que sejam específicos da implantação e colocação em operação de um hotel, há que se mapear, também de forma sistêmica, o escopo de trabalho associado à implantação e início da operação.

Este mapeamento do escopo é conduzido de forma a caracterizar quais sejam os aspectos diferenciadores entre um hotel e outros empreendimentos de real estate com estrutura de produto final semelhante.

Isto leva a recorrer aos referenciais teóricos específicos do gerenciamento de empreendimentos para este mapeamento de escopo. A principal ferramenta a ser empregada é a elaboração de uma EAP (Estrutura Analítica de projeto) típica para um hotel, no qual possam ser identificados, de um lado, o conjunto componente de sistemas e subsistemas correlato a edificações residenciais e de outro lado aquele que caracteriza os trabalhos de implantação e colocação em operação de um hotel.

Nesse contexto de identificação dos requisitos específicos da implantação de hotéis houve [1] identificação das características do negócio; [2] identificação de um padrão de organização do produto final hotel; [3] identificação do escopo do ciclo de implantação; [4] análise dos processos do ciclo de implantação de hotéis.

A identificação das características do negócio possibilitou a análise de quais restrições impostas pelo negócio influenciam no ciclo de implantação. Essas informações foram coletadas a partir da revisão bibliográfica.

A consolidação da identificação do escopo de implantação foi embasada em um levantamento de campo e um estudo de caso, devido à escassez de bibliografias referentes ao ciclo de implantação dos hotéis. O levantamento de campo foi realizado para identificar um padrão de organização oferecido pelos hotéis, a partir de informações disponíveis no sítio oficial de cada hotel na rede mundial de computadores.

O resultado desse primeiro levantamento de campo, juntamente com o conhecimento das etapas de construtivas de uma edificação, permitiu elaborar uma hipótese para o escopo do 
ciclo de implantação de hotéis ${ }^{7}$. Com isso, o estudo de caso possibilitou consolidar o escopo identificado junto a profissionais que atuam no mercado da implantação de hotéis.

O corpo de conhecimento adquirido sobre as restrições no negócio e escopo da implantação permitiu analisar as características do processo do ciclo de implantação específico dos hotéis, para assim identificar os requisitos da gestão de suprimento, com foco nos processos logísticos.

A metodologia de elaboração de cada uma dessas etapas é descrita juntamente com a apresentação dos resultados nas próximas seções.

\subsection{CARACTERÍSTICAS DO NEGÓCIO HOTELEIRO}

Conforme discutido no início desse capítulo, a finalidade de análise do negócio hotel é orientar para a identificação de características que interferem no ciclo de implantação de hotéis, principalmente aquelas que direcionam a operacionalização do empreendimento.

A receita de um empreendimento hoteleiro é proveniente principalmente das diárias pagas referentes ao serviço de hospedagem. E além dessa receita, existem as receitas provenientes dos serviços oferecidos como restaurantes, centros de convenções, spa.

Diversos estudos mostram que os empreendimentos de base imobiliária possuem um comportamento cíclico em relação à oferta de empreendimentos (CANTER; MAHER, 1998; WHEATON, 1999; GALLANGHER; MANSOUR, 2000). Asmussen (2004) realizou estudos em relação ao mercado dos empreendimentos hoteleiros, e identificou que os hotéis também possuem um comportamento cíclico.

Existem períodos de oferta crescente, devido o mercado consumidor estar favorável ao lançamento de novos empreendimentos. Nesse período, as diárias ${ }^{8}$ praticadas se apresentam em níveis próximos aos estabelecidos na formatação do empreendimento. Contudo, em certo momento, existe um excesso de oferta, e as diárias praticadas são reduzidas com a finalidade

\footnotetext{
${ }^{7}$ Essa hipótese é a elaboração de uma estrutura de partida para a formulação da EAP típica.

${ }^{8}$ A principal receita de um empreendimento hoteleiro é proveniente das diárias pagas referentes ao serviço de hospedagem oferecido. E além dessa receita, existem as receitas provenientes dos serviços oferecidos como restaurantes, centros de convenções, spas.
} 
de minimizar o impacto desse excesso de oferta. Com isso, ocorre a redução do crescimento da oferta, ou mesmo a sua estagnação. Em seguida, existe um momento que o mercado se equilibra novamente, e as diárias voltam a ser praticada em patamares próximos ao estabelecido na formatação do empreendimento. Na seqüência, ocorre a retomada do crescimento da oferta, e o ciclo de oferta do mercado hoteleiro inicia-se novamente.

Valendo-se dos seus estudos, Asmussen (2004, p. 71) concluiu que:

“a prevalecer um ambiente cíclico de oferta de hospedagem comercial transeunte, o ponto de inserção de um novo empreendimento neste ciclo terá um impacto na sua rentabilidade. Por mínimo que possa ser - de um ou dois pontos percentuais na taxa de retorno - esse impacto não é desprezível do ponto de vista do planejamento”.

É possível reconhecer, portanto que o período de lançamento do empreendimento hoteleiro influencia nos seus resultados. O empreendimento com lançamento no início do ciclo de crescimento da oferta apresenta perspectivas de maiores taxas de retorno e menores pay-back, do que os empreendimentos lançados nos outros períodos do ciclo, devido expectativa de que às diárias praticadas nos primeiros anos do seu lançamento estejam próximas dos patamares esperados. Com isso, o instante de lançamento de um empreendimento hoteleiro fica vinculado a um período de oportunidade do mercado.

Esse instante de lançamento determina o prazo de implantação do empreendimento, pois esse está vinculado há uma oportunidade do mercado, e caso o prazo não seja cumprido, poderá ter impacto significativo nos resultados esperados. Isso caracteriza uma rigidez de cenário quanto aos prazos de implantação e operacionalização desse tipo de negócio.

Os estudos iniciais do negócio também devem identificar o público alvo, juntamente com as suas necessidades e expectativas. Ou seja, devem ser identificados os serviços e as acomodações a serem oferecidos aos hóspedes, a fim de atender às necessidades do público alvo. O resultado do empreendimento depende da capacidade de atender às exigências do público alvo, pois o empreendimento que atender à essas exigências possui uma vantagem competitiva.

As análises econômicas e financeiras do produto formatado identificam a capacidade do empreendimento em oferecer certo patamar de resultados aos investidores. Ou seja, é esse público alvo, identificado com os estudos de mercado, que vai pagar pelos serviços oferecidos 
no hotel e possibilitar a rentabilidade esperada pelo investidor. O público alvo deve identificar que aquele empreendimento atende às suas necessidades, para então estar disposto a pagar pelos serviços oferecidos.

Ainda nas análises econômicas e financeiras são estudados os custos de implantação possíveis de atender aos patamares de resultados esperados. E é responsabilidade do gerenciamento da fase de implantação atender essas exigências, de escopo, prazo, custo e qualidade.

Outro aspecto que influencia na qualidade do gerenciamento é a relação entre os stakeholders do projeto. É necessário reconhecer o papel de cada um no negócio e os seus principais interesses.

Existem empreendimentos onde os investidores da implantação do empreendimento permanecem no negócio durante o período de operação. Nesse caso, a qualidade das atividades da fase implantação é balizada segundo o equilíbrio entre o custo de implantação e o custo de operação dos itens implantados, ou seja, os interesses são ponderados.

Outro tipo de estruturação, usual no Brasil, é o modelo de implantação onde o investidor sai do negócio no início da fase de operação. As unidades de hospedagem são vendidas até o final do ciclo de implantação e serão operadas por outros investidores. Com isso, é configurada uma situação, com diferentes investidores na fase de operação e implantação. O investidor presente na fase de implantação tem o interesse em minimizar os custos de implantação, com o objetivo de obter maiores resultados. Já os investidores da fase de operação desejam sistemas que reduzam os custos de operação do empreendimento, como menor consumo de energia e água, por exemplo.

Nesse estudo foi possível identificar as duas estruturações para o investimento em hotel. Na primeira os investidores das fases de implantação e operação são os mesmo, e na segunda, os investidores da fase de implantação e operação são diferentes.

Outro stakeholder no negócio hoteleiro, em qualquer uma das duas configurações apontadas, é a operadora.

As operadoras são empresas especializadas no gerenciamento de hotéis. A sua contratação engloba uma vasta experiência no ramo hoteleiro, contudo é necessário atender ao padrão de 
qualidade pré-estabelecido para as edificações e sistemas administrados por elas. Isso configura outro conjunto de exigências a ser atendido durante a fase de implantação do hotel.

Para o empreendimento a contratação de uma operadora traz como vantagem um nome conhecido, muitas vezes mundialmente. Isso atrai hóspedes de diversas localidades pelo padrão dessa determinada operadora a partir da bandeira $^{9}$ oferecida. $^{2}$

Configurada a composição dos stakeholders do negócio hoteleiro e suas necessidades, é responsabilidade da fase de implantação do empreendimento coordenar as necessidades de cada integrante do negócio, respeitando a formatação do empreendimento.

Diante das análises sobre o negócio hotel foram identificadas algumas características que influenciam o ciclo de implantação. Um das características que influencia é o prazo de implantação estar vinculado um período de oportunidade do mercado, o que conduz rigidez no prazo de implantação do empreendimento. Outra característica é a presença da operadora, como um stakeholder, com um conjunto de exigências a serem atendidas pelos processos do ciclo de implantação de hotéis, o que pode levar a necessidade de conciliar estas exigências durante a implantação do empreendimento.

\subsection{ESTRUTURA REFERÊNCIA DE ORGANIZAÇÃO DO PRODUTO HOTELEIRO}

A identificação de um padrão de organização dos hotéis administrados por operadoras foi desenvolvida a partir de uma análise estruturada das características essenciais que delimitam o produto de real estate final. Ou seja, envolveu identificar a estrutura que atende as necessidades de operação desse negócio. Essa estrutura será expressa em forma da EAP do produto hoteleiro.

O método de identificação desse padrão de organização do produto envolveu:

Delimitação do escopo da pesquisa em relação ao conjunto de empreendimentos a serem estudados;

\footnotetext{
9 A bandeira é a marca do hotel à ser oferecido ao cliente. Uma mesma operadora pode possuir diversas bandeiras e cada uma dessas possui um padrão e características específicas
} 
Identificação das características a serem levantadas dos empreendimentos;

Coleta de dados;

Identificação da EAP do produto hotel.

\section{Delimitação do escopo da pesquisa em relação ao conjunto de empreendimentos a serem estudados}

Nessa pesquisa foram analisados os empreendimentos localizados no Brasil e administrados por operadoras nacionais e internacionais. Essa premissa foi adotada devido à experiência dessas organizações no mercado hoteleiro, como relatado na seção anterior, e ao crescimento do número de empreendimentos no Brasil com a presença de operadoras na estrutura do negócio nos últimos anos.

De acordo com o escopo da pesquisa, aqui não serão estudados os empreendimentos com administração familiar.

Segundo FOB (2004) no Brasil existem 129 redes hoteleiras nacionais e internacionais. Dentre essas, 11 redes hoteleiras foram analisadas, cujo número de apartamentos deste conjunto representa cerca $40 \%$ dos apartamentos ofertados no Brasil.

Dentre as redes estudadas, 5 estão no grupo das 10 maiores redes hoteleiras do Brasil e 6 operadoras foram escolhidas dentre as demais empresas para minimizar eventuais vieses existentes apenas nas maiores redes, já que o levantamento tem o objetivo de abordar o produto hotel com a presença de operadora no negócio.

Foram consultadas as seguintes operadoras: Marriot, Hotéis Transamérica, Grupo Espírito Santo, Atlântica, Grupo Pestana, Rede Mabu, Accor Hotels, Chieko Aoki Management Company, Grupo Intercontinental, Caesar Park e Sonesta Hotels. 


\section{Identificação das características a serem levantadas de cada empreendimento}

A pesquisa identificou as características relativas aos aspectos físicos do empreendimento que são resultantes da fase de implantação, como quartos, restaurantes, bares e demais itens da organização a serem oferecidos por cada empreendimento.

Os itens dessa organização oferecida pelos hotéis foram identificados ao longo do desenvolvimento da pesquisa, pois para cada hotel pesquisado poderia existir algum aspecto novo a ser analisado. Por exemplo, durante o levantamento foi identificado que alguns hotéis possuem academia e sala de eventos, como também podem possuir heliponto ou espaço para shows.

Essa diversidade de possibilidades de itens da organização dos empreendimentos é resultante do ambiente competitivo dos hotéis ao buscarem atender, cada vez, mais as necessidades de um determinado segmento de mercado.

\section{Coleta de dados}

A fonte das informações sobre as características dos hotéis foi o seu o sítio oficial de cada empreendimento na rede mundial de computadores. O conjunto dos dados coletados está exposto no Apêndice 1. O critério da pesquisa buscou, por amostras sucessivas, estabelecer um padrão de organização para o produto. Desta forma, a partir do momento que novas amostras coletadas não trouxeram alterações significativas à estrutura do produto obtida a partir das amostras anteriores, admitiu-se a obtenção de uma estabilidade. Essa estabilidade foi o indicador que balizou o reconhecimento de um padrão de organização para o produto capaz de ser reconhecido em uma expressiva maioria dos empreendimentos hoteleiros.

Foi necessário analisar 42 empreendimentos para se obter um padrão básico para a estruturação de empreendimentos hoteleiros dentro do universo pesquisado.

O critério que balizou esse número de empreendimentos foi a necessidade da pesquisa de identificar um padrão para a organização ofertada pelos empreendimentos hoteleiros, a partir da concordância dos dados coletados. Ou seja, a cada coleta de dados de um determinado empreendimento ocorreu uma análise comparativa entre as organizações oferecidas pelos 
empreendimentos. E quando houve o reconhecimento de uma tendência de comportamento para a organização do produto a coleta de dados foi finalizada.

\section{Identificação da EAP do produto final hotel}

Dentre os hotéis pesquisados foi possível identificar que existe um programa funcional embasado em uma segmentação de mercado.

Existem hotéis voltados ao segmento público de negócios ${ }^{10}$, localizados nas grandes cidades. Esses hotéis podem possuir uma estrutura reduzida com apenas recepção, coffee-shop e estacionamento, como também podem possuir uma infra-estrutura diversificada.

Também existem os hotéis com vários restaurantes, spa, quadras, piscinas, serviço de recreação para crianças e adultos, ou seja, oferecem uma infra-estrutura diversificada para atender as necessidades de lazer dos hóspedes. Como também, com a finalidade de contornar eventuais sazonalidades ${ }^{11}$, existe uma estrutura para eventos de negócios e realização de atividades de trabalho nas dependências dos hotéis, com salões de exposição, salas de reuniões, internet banda larga, estações de trabalho com computadores, impressoras, aparelhos de fax e telefone.

Nesse cenário, foi possível encontrar um programa funcional básico para o empreendimento hoteleiro, identificado a partir dos itens da organização que os hotéis possuem em comum.

Essa organização compreende em uma estrutura de hospedagem e outra de suporte à hospedagem. A estrutura de hospedagem é composta por estoque de quartos e áreas de uso comum. As áreas comuns são compostas por restaurantes, bares, piscina, estrutura de lazer, estacionamento, sala de eventos. Os quartos e áreas comuns são formatados a partir dos requisitos do seu segmento de mercado. Para atender a necessidade dessa estrutura de hospedagem é implantada uma estrutura de suporte com ambientes como cozinha, lavanderia, depósitos e áreas para os funcionários.

\footnotetext{
${ }^{10}$ Público de negócios refere-se àquele que se hospeda com objetivo de viajem a trabalho, que desejam conforto depois de um dia exaustivo e infra-estrutura, caso necessite trabalhar no quarto, com mesa e iluminação apropriadas e acesso à rede mundial de computadores.

${ }^{11}$ A sazonalidade refere-se à grande diferença entre a quantidade de hóspedes durante os dias da semana e fim de semana, como também entre as estações do ano.
} 
Diante das informações obtidas no levantamento de campo foi possível elaborar a EAP conforme figura a baixo. Essa EAP ilustra um padrão de organização identificado nos hotéis analisados conforme e escopo da pesquisa.

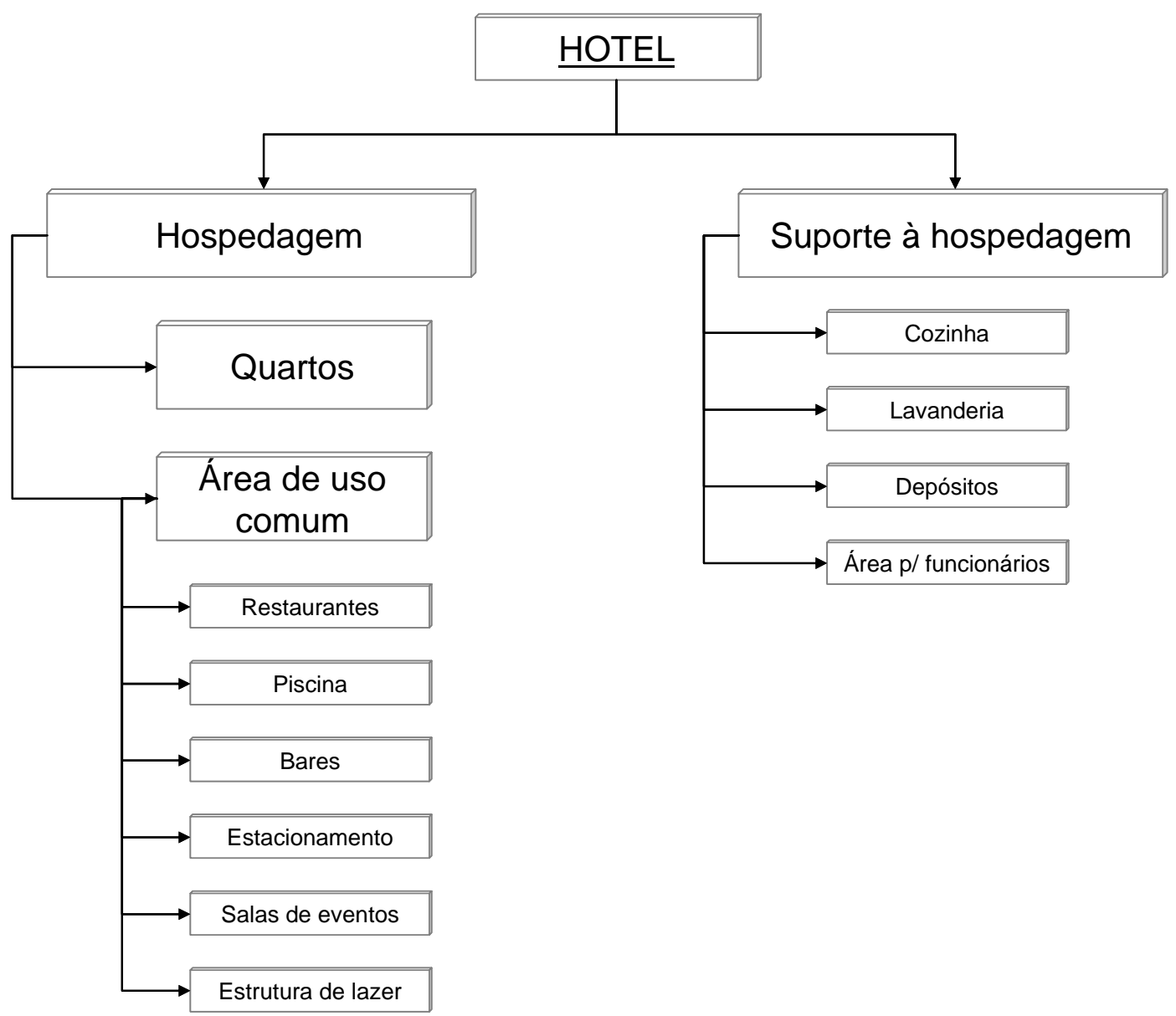

Figura 3 - EAP típica do produto hotel Fonte: Desenvolvido pela autora (2008)

Em um maior nível de detalhe da EAP, cada ambiente mencionado geralmente é composta por itens agrupados em mobiliário, equipamentos e utensílios e rouparia.

A depender do padrão do empreendimento, os quartos podem possuir uma estrutura reduzida com principalmente cama, armário, televisão e banheiro, como também existem quartos que podem ser verdadeiros apartamentos residenciais com sala mobiliada, estação de trabalho, banheiro com hidromassagem, cama, mesas e armários.

Observa-se que o produto hotel difere dos demais produtos de real estate devido aos equipamentos e mobiliários que compõem o produto final. Usualmente os edifícios residenciais são entregues sem esse tipo de equipamento, e os edifícios comerciais são entregues sem os acabamentos internos, cabe ao locatário ou proprietário a aplicação dos 
acabamentos como pisos e instalação dos mobiliários e equipamento. Essa mesma análise consideração vale para produtos como shopping centers. Já os hotéis são compostos tanto pela edificação com todos os acabamentos como pelos equipamentos e mobiliários necessários para a sua operacionalização.

Além disso, o processo de entrega dos hotéis ocorre ao mesmo instante com todos os itens da organização, evento que não ocorre, por exemplo, em um empreendimento residencial já que os apartamentos são entregues aos proprietários em tempos diferentes a partir de uma vistoria com cada proprietário.

A identificação de uma organização padrão do produto empreendimento hoteleiro representa a configuração do produto a ser entregue após a o ciclo de implantação do empreendimento. Na próxima seção serão analisados os processos de trabalho da fase de implantação necessários para a obtenção desse produto.

\subsection{ESCOPO DO CICLO DE IMPLANTAÇÃO DE HOTÉIS}

O escopo da implantação do empreendimento hoteleiro envolveu identificar os pacotes de trabalho necessários para produzir a organização do produto final projetada para o empreendimento. Essa etapa de pesquisa identificou os pacotes de trabalho e respectivas etapas de produção para a obtenção do produto final identificado na seção anterior.

O método para a identificação do escopo de implantação inclui estabelecer primeiramente, uma hipótese para o escopo de implantação e, em seguida, consolidar esse escopo com profissionais que atuam no mercado na implantação de empreendimentos hoteleiros.

A consolidação da hipótese foi realizada a partir de um estudo de caso. O estudo de caso é um método de pesquisa para a investigação de inferências válidas a partir de eventos que se encontram fora dos limites do laboratório, ao mesmo tempo, em que mantém os objetivos do conhecimento compartilhado com a ciência laboratorial (YIN, 2005).

A consolidação da hipótese não tem como objetivo elaborar um escopo padrão de trabalho aplicável a todos os empreendimentos hoteleiros, mas sim, identificar o conjunto de pacotes 
de trabalho característico aos empreendimentos hoteleiros abordados como escopo da pesquisa. Aqui serão enfatizados os aspectos característicos, isto é, típicos na implantação de hotéis.

Contudo, para a identificação desse conjunto de pacotes de trabalho característicos dos hotéis é necessário identificar também os trabalhos e processos executados em qualquer empreendimento de real estate, devido à necessidade de identificar as interfaces entre o escopo usual aos empreendimentos de real estate e o escopo característico à implantação de hotéis.

A seguir é apresentada uma proposta de partida para o escopo da implantação típica de um hotel, bem como, o método da consolidação da hipótese ${ }^{12}$.

\section{Primeira hipótese para o escopo da implantação de hotéis}

A hipótese de partida para o escopo da implantação de hotéis, a partir da identificação dos pacotes de trabalho, ocorreu com base no padrão de organização do produto final hotel, confrontado com os pacotes de trabalho típicos da construção de uma edificação residencial.

Um nível de detalhamento maior que o pacote de trabalho está associado a um determinado ambiente organizacional e uma política de execução específica. Desta forma, não cabe, neste trabalho, detalharmos a EAP até um hipotético nível hierárquico menor que os pacotes de trabalhos, pois isto implicará na arbitragem de condições de execução para um empreendimento até aqui abordado de modo conceitual e no nível tático ${ }^{13}$ de gerenciamento.

Por outro lado, como preconizado pelo (PMI, 2004) há que se consultar as partes envolvidas para o adequado estabelecimento não só dos pacotes de trabalho mas também de sua hierarquia de inter-relacionamento. Isto é feito, neste trabalho, através de consulta aos profissionais sobre as atividades correspondentes ao ciclo de implantação de hotéis.

Os pacotes de trabalho associados à hipótese do escopo de implantação de hotéis estão listados e descritos na Figura 4.

\footnotetext{
12 O estudo de caso está descrito em detalhes no Apêndice 3.

${ }^{13}$ Os níveis hierárquicos de gerenciamento são estratégico, tático e operacional. Maiores detalhes de níveis de gerenciamento em Rocha Lima (1998). Essa pesquisa aborda o nível tático.
} 


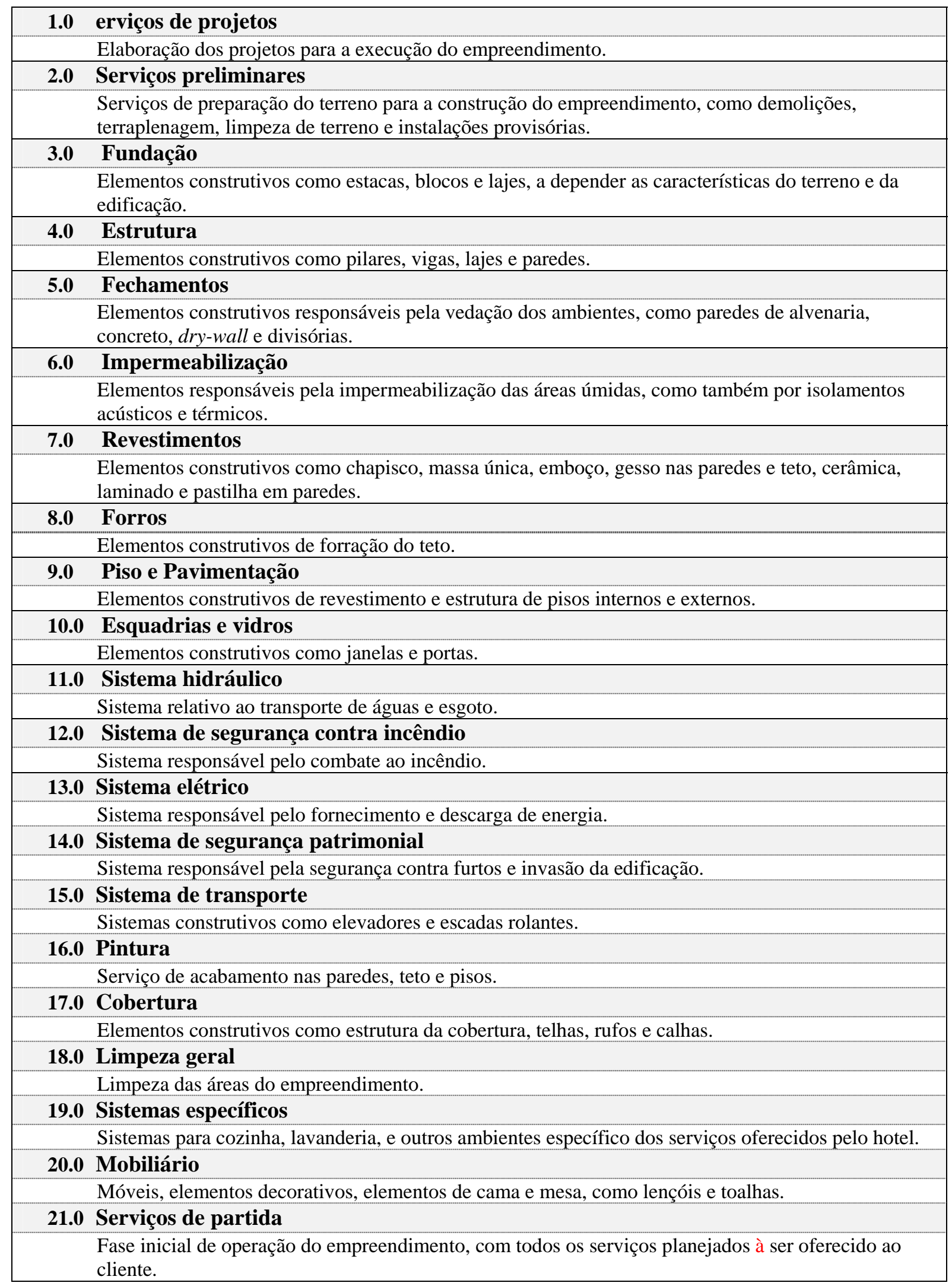

Figura 4 - Hipótese do escopo da implantação de hotéis

Fonte: Desenvolvido pela autora (2008) 


\section{Consolidação da Hipótese de Partida- Estudo de Caso}

O método de estudo de caso é utilizado quando com a finalidade de lidar com condições contextuais, acreditando que elas poderiam ser altamente pertinentes a fenômenos do estudo (YIN, 2005). No presente contexto, a identificação do escopo de implantação do empreendimento conduz à análise das necessidades de processos gerenciais capazes de atender às características exclusivas de suprimento da implantação de hotéis, com foco nos processos de gerenciamento do fluxo desses insumos.

Graças à essa necessidade, o estudo de caso, com profissionais que atuam no mercado de implantação de empreendimentos hoteleiros, permite explorar a hipótese até aqui formulada.

Segundo Yin (2005), as atividades de execução do estudo de caso são ${ }^{14}$ :

Definição e Planejamento - Inclui o desenvolvimento da teoria, seleção dos casos e elaboração do protocolo do estudo de caso;

Preparação, Coleta e Análise - Condução dos casos e elaboração dos relatórios;

Análise e Conclusões - Análise cruzada dos casos, modifica a teoria, desenvolve implicações políticas e escreve um relatório de casos cruzados.

\section{Definição e Planejamento}

O objetivo do estudo de caso é consolidar o escopo da implantação de empreendimentos hoteleiros identificados a partir de uma hipótese, embasada no levantamento de campo e pacotes de trabalho da construção de uma edificação.

\section{Preparação, Coleta e Análise}

O instrumento de coleta das informações foi um questionário semi-estruturado. $\mathrm{O}$ questionário foi aplicado a profissionais envolvidos na implantação de empreendimentos hoteleiros. Houve o cuidado de entrevistar profissionais envolvidos nas diversas organizações responsáveis pela implantação do empreendimento, como construtora, grupo investidor e

\footnotetext{
${ }^{14} \mathrm{O}$ Apêndice 3 descreve em detalhes as atividades realizadas no estudo de caso.
} 
operadora. Isso foi feito, caso existissem, divergências entre as respostas de cada grupo, como também para coletar as experiências das diversas organizações presente no empreendimento.

Foram entrevistados cinco profissionais, e a cada entrevista houve uma avaliação da validade da hipótese inicial, com a finalidade de identificar, caso existisse, grandes discrepâncias sobre a hipótese inicial. Em linhas gerais, para cada entrevistado foi feito o seguinte questionamento: [1] existe algum aspecto dessa EAP que não seja válido para os empreendimentos já gerenciados? [2]existe alguma incompatibilidade com os empreendimentos já gerenciados?

O protocolo do estudo de caso está descrito no Apêndice 3.

\section{Análise e conclusões}

Em suma, a hipótese inicial pode ser empregada como escopo referencial na implantação de hotéis, de acordo com o escopo da pesquisa. Nenhum dos entrevistados retirou algum pacote de trabalho, e houve apenas a identificação de três pacotes de trabalhos adicionais (paisagismo, sistema de condicionamento de ar e sistema de automação), e nenhum pode ser considerado como característico apenas de empreendimentos hoteleiros.

Diante desses resultados pode-se concluir que os itens da Figura 5 podem ser agrupados em itens característicos aos hotéis e itens típicos a implantação de empreendimentos residenciais. 


\begin{tabular}{|l|l|}
\hline $\begin{array}{l}\text { Pacotes de Trabalho típicos dos } \\
\text { empreendimentos residenciais }\end{array}$ & $\begin{array}{l}\text { Pacotes de Trabalho típicos dos } \\
\text { empreendimentos hoteleiros }\end{array}$ \\
\hline \multicolumn{2}{|l|}{} \\
\hline Serviços de projetos & Sistemas específicos \\
\hline Serviços preliminares & Mobiliário \\
\hline Fundação & Serviços de partida \\
\hline Estrutura & \\
\hline Fechamentos & \\
\hline Impermeabilização & \\
\hline Revestimentos & \\
\hline Forros & \\
\hline Piso e Pavimentação & \\
\hline Esquadrias e vidros & \\
\hline Sistema hidráulico & \\
\hline Sistema de segurança contra incêndio & \\
\hline Sistema elétrico & \\
\hline Sistema de segurança patrimonial & \\
\hline Sistema de transporte & \\
\hline Pintura & \\
\hline Cobertura & \\
\hline Limpeza geral &
\end{tabular}

Figura 5 - Identificação dos itens específicos de hotéis

Fonte: Desenvolvido pela autora (2008)

Em síntese, a EAP de um hotel pode ser desdobrada ao longo do seu ciclo de vida (implantação e operacionalização) em dois grandes subconjuntos: geral e específico, onde o último identifica e agrega aqueles pacotes de trabalho que distinguem o hotel de um empreendimento residencial.

O primeiro nível representa o empreendimento como um todo, seu segundo nível é orientado ao seu ciclo de vida, donde teremos: projetos (no sentido de seu design), suprimento (desdobrado no suprimento de insumos característicos aos empreendimentos residenciais e hoteleiros), implantação (construção da edificação e instalações operacionais, tais como os equipamentos específicos da operacionalização do hotel), partida (colocação em operação e mobilização do respectivo pessoal) e gerenciamento (coordenação da execução dos pacotes de trabalho). Em um terceiro nível poderão ser alocados os seguintes sistemas componentes:

Projetos: Formatação e Programa Funcional, Edificação e Instalações Operacionais.

Suprimentos: Geral e Específico.

\section{Implantação:}


- Pacotes comuns ao escopo dos empreendimentos de real estate: Fundações, Estrutura, Vedações e Revestimentos, Sistemas e Instalações Prediais (Facilities); Urbanização e Entrega da Edificação.

- Pacote característico do escopo hoteleiro: Instalações Operacionais.

Partida: Colocação em Operação e Mobilização de Pessoal.

Observa-se que todos os sistemas componentes indicados como Instalações Operacionais são específicos de edificações destinadas à exploração do negócio de hotelaria, e que isto traz um necessário ajuste do escopo do sistema de gerenciamento.

O sistema de gerenciamento é diferenciado devido a necessidade de gestão do suprimento de insumos não usuais a empreendimentos de real estate. O suprimento destes insumos, independente dos respectivos processos de contratação, se dá em um período de tempo estreito, ao final da etapa de implantação, e como pré-requisito para a etapa de partida do hotel. Soma-se a essa restrição de prazo o fato desses insumos, usualmente, se apresentam em grande quantidade e diversidade.

Os processos de suprimento dos insumos característicos à implantação de hotéis apresentam interfaces tanto entre si, como com o escopo de implantação tipicamente residencial. Essas interfaces são capazes de interferir na condução de atividades associadas ao escopo da implantação tipicamente habitacional do hotel, bem como com a própria operacionalização do hotel.

Saliente-se que não é propósito deste trabalho discorrer sobre processos de desenvolvimento de projetos (no sentido de seu design) de edificações, donde as considerações feitas quanto a este aspecto da EAP são genéricas e tem o propósito de encaminhar a formatação da EAP para que se identifiquem os aspectos específicos de um hotel. Contudo cabe a ressalva que a elaboração dos projetos executivos do empreendimento envolve a integração com o mobiliário e equipamentos do empreendimento. Essa integração dos aparelhos específicos deve ocorrer desde a etapa de projeto do empreendimento.

Na etapa de implantação, a especificidade do hotel reside na instalação dos equipamentos operacionais, como equipamentos específicos e mobiliários ao final do ciclo de implantação 
(ver itens em cinza da Figura 6). É nessa etapa que ocorre a integração desses aparelhos específicos com o empreendimento.

Também ao final da implantação do empreendimento é realizada a etapa de partida onde ocorre a integração do time de operação com o empreendimento. Observa-se que na fase final da implantação do hotel ocorre sobreposição de suas atividades com o termino da edificação com seus acabamentos, instalação dos equipamentos hoteleiros específicos e processos de partida.

Em suma, a fase do ciclo de vida da implantação do hotel, delimitada pelo final das obras e início das atividades da fase de partida é caracterizada, por um intenso fluxo de insumos, não usuais a empreendimentos residenciais, com alto grau de interface, diversidade e quantidade. Além disso, a integração desses insumos - sistemas, equipamentos, mobiliários e acessórios é capaz de interferir tanto com andamento das obras de caráter residencial, como nas atividades de partida da operacionalização do hotel.

Este quadro de condições de rigidez na data de entrega, pressão de prazo, complexidade de coordenação e integração pode se tornar um ofensor ao cumprimento de prazos de início de operação do empreendimento.

O que pode levar o empreendimento a um dilema: atrasar significativamente a inauguração ou dar a partida sem que esteja funcionando operacionalmente. Em ambas as situações, um aspecto relevante é o potencial comprometimento da imagem do empreendimento, bem como do relacionamento com a futura operadora, e a perda da qualidade dos serviços oferecidos inicialmente devida à falta da infra-estrutura planejada.

Na próxima seção há um detalhamento desse cenário de implantação dos empreendimentos hoteleiros, com foco naqueles processos que diferenciam os hotéis dos empreendimentos residenciais. 
Capítulo 02 - Empreendimentos Hoteleiros 32

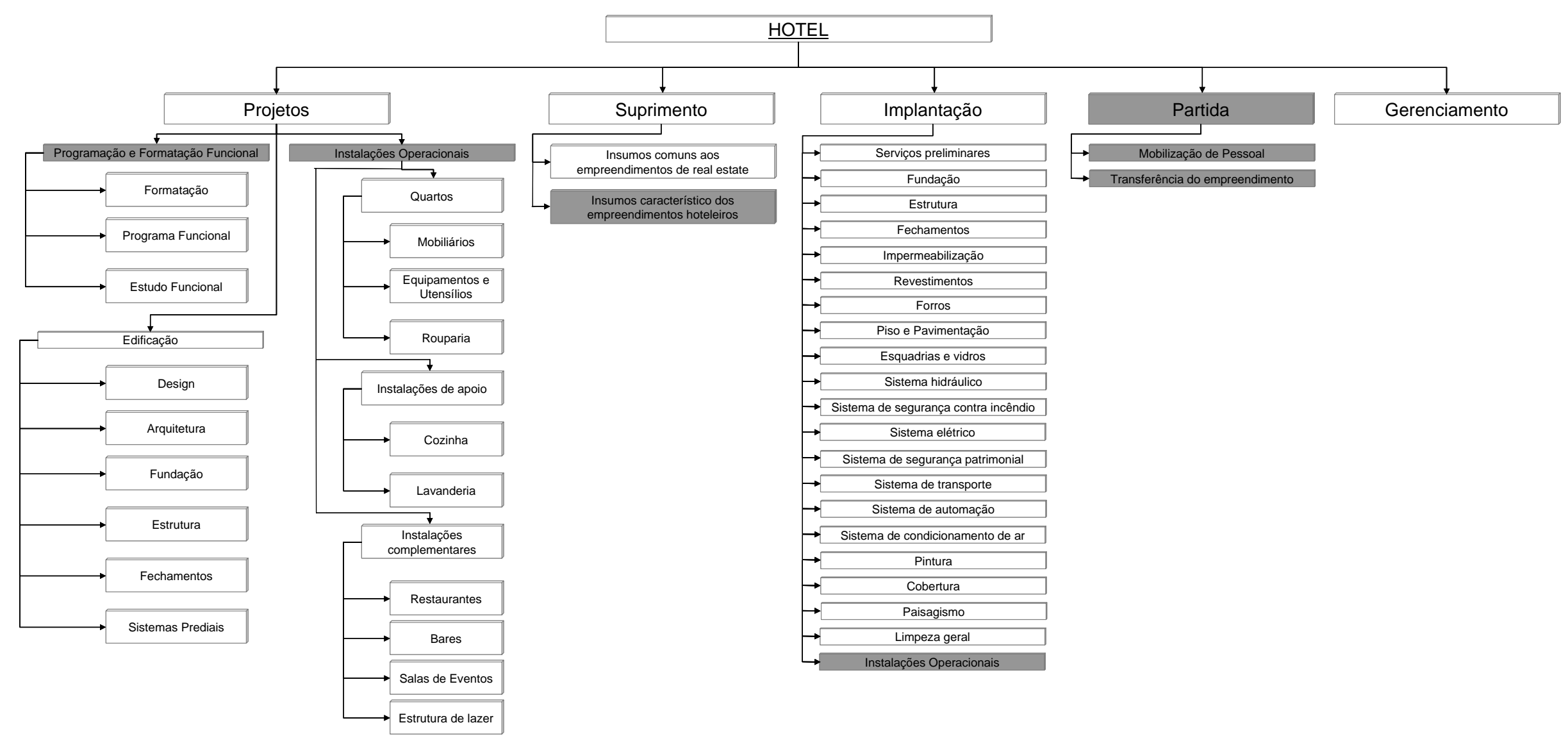

Pacotes de trabalho característico da implantação de hotéis

Figura 6 - EAP de implantação

Fonte: Desenvolvido pela autora (2008) 


\subsection{CICLO DE IMPLANTAÇÃO DE EMPREENDIMENTOS HOTELEIROS}

O ciclo de vida típico de um projeto envolve as fases de concepção, planejamento, execução e termino (CLELAND; KING, 1983). E nesse trabalho é analisado o ciclo de implantação do empreendimento hoteleiro, embasada na ótica do ciclo de vida de um projeto.

Nesse trabalho foram identificadas as características específicas do ciclo de vida da implantação de hotéis a partir do referencial teórico analisado sobre as atividades de implantação versus as características do negócio que influenciam esse mesmo ciclo. Uma revisão bibliográfica sobre o ciclo de vida de projetos busca suportar a análise do ciclo de implantação de hotéis.

Conforme a EAP indicada na Figura 6, a implantação de hotéis envolve conjuntos de atividades agrupadas em projeto, suprimento, implantação, partida e gerenciamento. Dentre essas atividades existem aquelas similares aos empreendimentos de real estate, como o projeto residencial, e as atividades típicas do hotel, como a execução das instalações operacionais.

Nesse trabalho serão consideradas as atividades típicas da implantação de hotéis, as instalações operacionais, o conjunto de atividade da partida e gerenciamento específico para as atividades de implantação de hotéis.

Com isso, o ciclo de vida da implantação de hotéis será analisado com o objetivo de delimitar as etapas nas quais os processos usuais de gerenciamento devem ser complementados.

\section{Ciclo de Vida - Fase de Concepção}

A fase de concepção de um projeto engloba identificação das necessidades, analise de viabilidade, identificação de alternativas, preparação de propostas, elaboração de orçamento e programação básica e identificação do time do projeto (CLELAND; KING, 1983).

Nesse trabalho não será abordada a fase de concepção de empreendimentos hoteleiros. As informações formuladas nessa fase são premissas para a implantação do empreendimento. 
Contudo, diante dos resultados dos estudos realizados anteriormente foi possível observar a necessidade da integração dos projetos de design ${ }^{15}$ com os demais projetos executivos do empreendimento.

Desde o início da fase de projetos deve ser definida a disposição do mobiliário para a definição dos demais projetos. Ou seja, com a definição do design é possível identificar os pontos de energia para o projeto elétrico, o melhor posicionamento dos pilares para concepção do projeto estrutural. A partir dessa necessidade do negócio é fundamental a definição do design para a definição dos demais projetos.

Andrade (2002) ressalta a importância da integração entre os projetos de arquitetura e design desde o início do empreendimento. Como também deve existir a integração de todos os projetos desde a fase de concepção. Pois um erro nessa fase pode acarretar em inúmeros retrabalhos a depender da quantidade de apartamentos do empreendimento. O projeto de interiores do quarto de um hotel, não é apenas uma decoração. Cada objeto possui uma função e a localização pré-determinada. Por exemplo, a luminária de uma mesa de trabalho deve possuir a quantidade de lumens que proporcione conforto enquanto o hóspede estiver lendo ou ao computador. Como também os pontos de luz já devem ser determinados inicialmente no projeto com os projetistas de interiores e evitar reposicionamento de interruptores e tomadas na atividade de instalação.

A estruturação de um protótipo do quarto é uma opção de analise quanto às decisões de formatação desse ambiente (Gonçalves, 2002). Essa medida evita re-trabalhos na fase de execução do empreendimento, como também possibilita a redução dos riscos com relação ao aumento de custo e prazo estabelecidos para o empreendimento.

Essa diretriz da fase de concepção, dos projetos executivos refletirem as necessidades do produto, deve ser seguida nas demais fases da implantação com a execução dos processos.

\footnotetext{
${ }^{15}$ Design refere-se aos projetos de disposição do mobiliário e decoração, como também a identificação das suas especificações. Corresponde ao projeto de arranjo final do empreendimento.
} 


\section{Ciclo de Vida - Fase de Planejamento}

A fase de planejamento engloba implementação da programação, condução de estudos e análises, projetos, construção e testes de protótipos, análise de resultados, aprovação para a produção (CLELAND; KING, 1983). Essa corresponde à fase de elaboração de diretrizes, embasada nas formulações da fase de concepção, para as fases de execução e término do empreendimento.

A diretriz para o planejamento da implantação de um hotel é direcionar os pacotes de trabalho ao longo das etapas construtivas para que esses sejam executados nos padrões impostos pelas especificações e prazo estipulado. Pois os atrasos ou não conformidades que ocorrem nessas etapas, possivelmente refletirão na etapa mais critica do empreendimento, ao final do ciclo de implantação onde ocorre um grande número de atividades paralelas.

Outra vertente de diretriz para o planejamento corresponde a analisar as restrições do empreendimento ao final do ciclo para a realização das atividades. A análise ocorre em relação a identificar problemas que possam ocorrer no curto espaço de tempo da implantação dos equipamentos operacionais e partida, essa é uma ação proativa com a finalidade de atender à baseline do empreendimento.

Ainda, a análise deve focar na implantação dos quartos pela sua multiplicidade e diversidade de componentes, como também por geralmente representar a maior área construída do empreendimento. O planejamento coerente do empreendimento, principalmente com relação aos quartos, acarreta na redução dos riscos em atender as exigências de operação do empreendimento.

Em suma, a característica específica do planejamento da implantação de hotéis é direcionar os processos de implantação para que no curto espaço de tempo ao final do ciclo de implantação, onde ocorrem a instalação dos equipamentos operacionais e partida, os pacotes de trabalho sejam realizados conforme a baseline do empreendimento. E para isso é necessário identificar os potenciais problemas em relação ao escopo de trabalho. 


\section{Ciclo de Vida - Fase de Execução}

A fase de execução engloba construção de ferramentas, desenvolvimento de suporte de requisitos, produção do sistema, verificação de performance, modificações requeridas (CLELAND; KING, 1983). As atividades dessa fase têm como objetivo atender às diretrizes apontadas pelo planejamento do empreendimento.

Na fase de execução do ciclo de vida de hotéis ocorre a aquisição e instalação dos mobiliários e equipamentos específicos.

O conjunto desses processos deve ocorrer desde a fase de planejamento e termina com a instalação dos insumos ao final do ciclo de implantação. Na fase de planejamento, ocorrem análises das especificações dos insumos e seus fornecedores, todos esses integrados às necessidades do empreendimento, como também são identificados os prazos para que os insumos estejam disponíveis para o empreendimento no tempo requerido. Para os insumos operacionais dos hotéis existe uma grande demanda em um curto espaço de tempo ao final do ciclo de implantação empreendimento.

Ao mesmo tempo da construção da edificação, processos de suprimento dos insumos operacionais são realizados para que ao final das atividades construtivas insumos operacionais do hotel estejam disponíveis.

Os diversos insumos devem estar estocados ou com a entrega prevista no tempo necessário. A estocagem depende de espaço apropriado para o armazenamento de mobiliários, tais como televisões, camas, rouparia. Já a entrega no tempo certo depende das condições de contratação. Essas duas variáveis - estocagem e prazo de entrega - devem ser analisadas constantemente na contratação dos serviços e insumos.

As condições de armazenagem e credibilidades nos prazos de entrega indicados pelos fornecedores são critérios a serem analisados constantemente no processo de suprimento dos itens característicos aos hotéis, pois o atraso na entrega dos mesmos pode acarretar em atrasos significativos no lançamento do empreendimento. 
Esses processos de análise das condições de suprimento em relação ao escopo, custo e prazo, análise dos fornecedores e armazenagem são uma preparação para a disponibilização do insumo nos padrões requeridos pelo hotel.

Diante dessas necessidades, os processos logísticos ao gerenciar o fluxo de insumos, auxiliam a atender aos prazos e condições de fornecimento com a busca de soluções para condições impostas pelo cenário de implantação do hotel.

As atividades de construção da edificação dos empreendimentos hoteleiros são similares a outros empreendimentos como edifício comercial e shopping centers. Salienta-se que surge uma tendência a ao emprego de tecnologias construtivas que reduzam o ciclo de implantação, tais como pré-moldados, dry-wall, banheiros prontos, estruturas metálicas, as quais, em si mesmas, não são objeto do presente trabalho, orientado apenas para os requisitos de gestão da logística específica para a implantação e partida deste tipo de empreendimentos. Os hotéis Hilton Berrine, Ceasar Park Guarulhos são exemplos de implantação de hotéis que utilizaram um conjunto apropriado do tecnologias com a finalidade de reduzir o prazo de implantação.

Quanto aos aspectos gerenciais que diferenciam um hotel de outros empreendimentos, estes se voltam para o suprimento e instalação daqueles sistemas identificados no escopo da Figura 6 como específicos deste tipo de empreendimentos.

Um aspecto a ser enfatizado na implantação de hotéis, é a implantação dos quartos. Consiste na instalação de diversos componentes, e esses componentes são multiplicados pelo número de quartos a serem implantados. Além disso, cada quarto geralmente possui uma pequena área onde devem ser implantados e instalados todos os insumos necessários para a sua operação valendo-se da seqüência lógica de realização das atividades.

Nesse cenário de implantação dos quartos, com diversas atividades que ocorrem diversas vezes e em um curto espaço de tempo, o suprimento dos insumos é critico. Esse suprimento deve analisar as condições físicas do empreendimento (se é um empreendimento horizontal ou vertical), como também, os espaços disponíveis para disponibilizar esses insumos no ambiente em que é necessário. Os times de instalações devem estar sincronizados e com a informação do escopo de seu trabalho. Nessa etapa o planejamento prévio considerando as restrições tanto do hotel como de seus fornecedores é fundamental. 
Em suma, a característica específica da fase de execução de hotéis está relacionada às exigências de implantação e instalação de insumos específicos ao empreendimento em curto espaço de tempo ao final do ciclo de implantação. E essas exigências são enfatizadas na implantação dos quartos, devido à sua multiplicidade e importância para o empreendimento.

\section{Ciclo de Vida - Fase de Término}

A fase de término engloba treinamento de pessoal, transferência de material, transferência de responsabilidade, liberação de recursos, remanejamento do time do projeto (CLELAND; KING, 1983).

A fase inicial de operação do empreendimento exige a integração do empreendimento com a sua time de operação. O sucesso do negócio depende da qualidade dos serviços oferecidos aos clientes. De nada adianta a implantação de um sistema de ar condicionado todo automatizado se não existem funcionários capacitados para a sua operação, como também, de nada adianta a compra dos lençóis mais caros se não se sabe conservar a qualidade durante a sua vida útil. Essa fase corresponde à transferência do empreendimento para os responsáveis pela sua operação.

Essa fase ocorre ao final da fase de implantação, contudo, para atender as necessidades do negócio, geralmente essas fases se sobrepõem. Nesse período ocorre a finalização das atividades da edificação com os acabamentos, a instalação do mobiliário e equipamento específico e a transferência do empreendimento para a operadora.

Esse cenário é caracterizado pela presença de diversos stakeholders como construtora, instaladoras e operadoras. E com a finalidade de antecipar a integração da operadora ao empreendimento essa participa ativamente nas atividades finais com a limpeza do empreendimento, colocação de móveis menores e treinamento em relação ao funcionamento dos aparelhos e seus processos para a operação. Por exemplo, as camareiras são contratadas ainda na fase de implantação para a colocação de objetos pequenos do mobiliário e limpeza dos quartos. 
Em suma, a característica específica da fase de término, partida dos hotéis, é a integração da operadora ao empreendimento, em paralelo com as atividades de implantação, com a finalidade de obter um empreendimento pronto para operar logo ao final do ciclo de implantação.

O ciclo de implantação dos empreendimentos hoteleiros é caracterizado principalmente pela execução de atividades, em um curto espaço de tempo ao final do ciclo, compostas pela sobreposição das atividades finais de uma obra em conjunto com a instalação do mobiliário e equipamentos e partida. Nesse cenário de sobreposição de atividades e rigidez de prazo, o suprimento torna-se crítico, devido à quantidade e diversidade de insumos requeridos nesse curto espaço de tempo. Essas situações introduzem a necessidade de adicionar processos gerenciais de suprimento não usuais na implantação de empreendimentos, em relação a escopo, custo e prazo, com a finalidade de auxiliar a atender à baseline.

Esse cenário produz demandas, como os residenciais, e criam a necessidade de processos gerenciais que se adaptem a esse cenário. 


\section{A GESTÃo DA LOGÍSTICA COMO SUPORTE AOS PROCESSOS DO GERENCIAMENTO DE PROJETOS}

O presente capítulo conduz uma revisão teórica sobre o tema da gestão da logística de modo a permitir, posteriormente, uma transposição crítica desta referência para o ambiente da implantação de hotéis.

Aqui a logística aqui não será abordada na sua forma clássica, mas sim como um conjunto de processos integrados ao gerenciamento de projetos, com o objetivo estrutura o gerenciamento do fluxo de insumos.

O gerenciamento de projetos (GP) é a aplicação de conhecimento, habilidades, ferramentas e técnicas às atividades do projeto a fim de atender aos seus requisitos (PMI, 2004, p.8). Os processos, segundo o PMI (2004), estão organizados em nove áreas de conhecimento conforme descrito a seguir, que visam atender aos objetivos do projeto.

* Gerenciamento de integração - Envolve os processos de integração do diversos elementos de gerenciamento do projeto.

Gerenciamento de escopo - Envolve os processos de análise e verificação das atividades necessárias para finalizar o projeto com os objetivos estipulados.

* Gerenciamento de prazo - Envolve os processos de análise e verificação dos prazos de entrega do projeto.

Gerenciamento de custos - Envolve os processos de planejamento, estimativa, orçamentação e controle dos custos.

* Gerenciamento da qualidade - Envolve os processos necessários para o projeto finalizar com objetivos e desempenhos almejados.

Gerenciamento de recursos humanos - Envolve os processos que organizam e gerenciam o time de projeto. 
Gerenciamento das comunicações - Envolve os processos relativos à geração, coleta, disseminação, armazenamento e destinação das informações do projeto.

Gerenciamento de riscos - Envolve os processos de identificação, análise e monitoramento dos riscos, como também respostas aos riscos.

* Gerenciamento de suprimentos - Envolve os processos de gestão do fornecimento de insumos para o projeto.

A logística será integrada aos processos do gerenciamento de suprimento. Primeiramente serão expostos e analisados os conceitos da logística e em seguida o mesmo ocorre com seus processos e operações no cenário do ciclo de implantação de empreendimentos.

\subsection{EVOLUÇÃO HISTÓRICA - CONCEITOS DA LOGÍSTICA}

A evolução histórica do processo logístico é demonstrada de maneira sucinta aqui nessa seção, e está ilustrada na Figura 7. O objetivo dessa demonstração é conceituar a logística no seu estado atual.

\section{$\underline{\text { Antes de } 1945}$}

A logística foi analisada primeiramente, no âmbito acadêmico, no início do século 20. Esses primeiros estudos discutiram custos e fatores de distribuição de produtos rurais, aspectos das estratégias logísticas, a introdução do conceito de utilidade no marketing e canal de distribuição (LAMBERT; STOCK, 1993). Ballou (1993) e Lambert e Stock (1993) indicam o trabalho de Fred Clark, em 1922, Principles of Marketing, como um dos precursores no estudo do canal de distribuição, pois esse trabalho relata a relação do canal de distribuição com o marketing. Nesses mesmos anos, Munk (1936), no The Journal of Marketing, demonstrava a preocupação com o alto custo da distribuição de commodites, tanto na Europa como nos Estados Unidos. O processo logístico era tratado principalmente no âmbito da agricultura, em relação à distribuição de produtos rurais. 


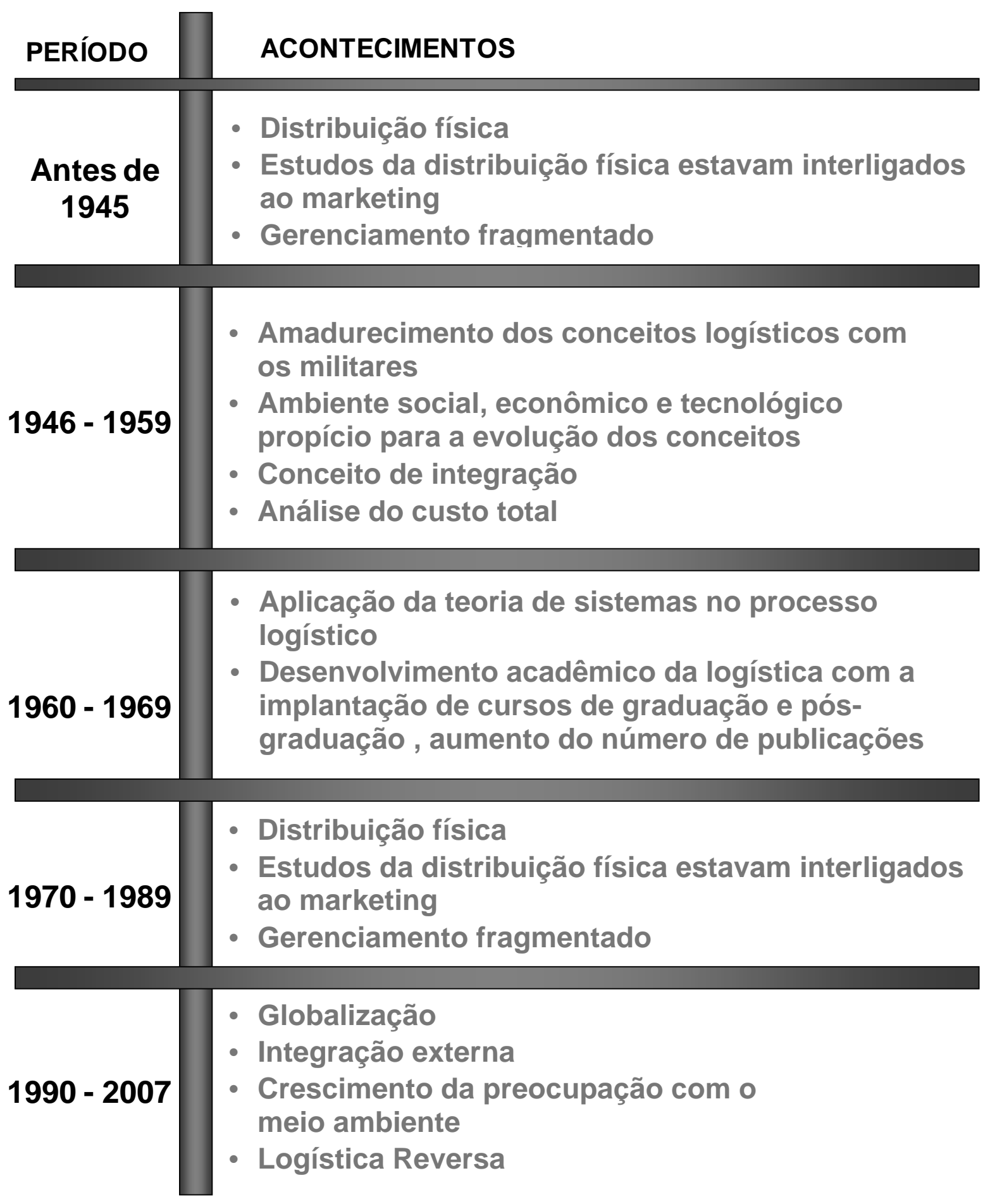

Figura 7 - Evolução do Conceito Logístico Fonte: Desenvolvido pela autora (2008) 
A logística, nessa época, denominava-se distribuição física, cuja definição é: "as atividades preocupadas com o movimento eficiente de produtos acabados a partir do final da linha de produção até o consumidor” (MASTERS; POHLEN, 1994, p.14). Ou seja, a logística englobava apenas o processo de distribuição do produto acabado até o consumidor.

Ainda nesses mesmos anos, as empresas tratavam o gerenciamento das operações logísticas de forma fragmentada (BALLOU, 1993; MASTERS; POHLEN, 1994). O transporte, os estoques e o processamento de pedidos dos produtos acabados eram gerenciados pelos diversos setores da empresa, como a produção, financeiro, marketing, vendas.

Em suma, a logística até a Segunda Grande Guerra (1939-1945), é definida pela distribuição física do produto acabado até o consumidor, realizado por um gerenciamento de forma fragmentada. Inicialmente os estudos da logística estavam interligados aos conceitos do marketing, devido às necessidades dos setores produtivos fazer seus produtos chegar ao cliente.

\section{$1946-1959$}

Com a Segunda Grande Guerra, os conceitos logísticos amadureceram (BALLOU, 1993). As operações militares logísticas demonstraram como as atividades de distribuição podem ser integradas em um único sistema (LAMBERT; STOCK, 1993). Os resultados alcançados mostraram uma nova forma de estruturar as atividades do processo logístico.

A condução das atividades de movimentação, transporte e estocagem durante a Segunda Grande Guerra levaram à evolução do seu método de execução. Os militares foram os primeiros a reconhecer as atividades logísticas como uma vantagem estratégica. Eles enxergaram a necessidade de estruturar o fluxo dos insumos de maneira integrada.

Antes, a logística era gerenciada por diversos setores, e com o passar dos anos, o conceito de gerenciamento de modo centralizado foi absorvido, ou seja, o setor logístico, um novo setor incorporado na empresa, gerenciava de modo centralizado as operações do fluxo de insumos. Contudo, esse conceito apenas foi incorporado pelas empresas anos mais tarde, como será descrito na seqüência da evolução histórica. 
Os bons resultados dos militares com a execução das operações logísticas de forma integrada consolidaram os conceitos e a prática. Entretanto, outros fatores também puderam ser identificados como fatores influenciadores do desenvolvimento da logística. Bowersox (1969) indica a utilização de novas tecnologias e o ambiente econômico instável propício para melhores sistemas de controle, como fatores impulsionadores do desenvolvimento logístico. Ballou (1993) indica, além dos fatores citados acima, as alterações nos padrões e atitudes da demanda dos consumidores.

A seguir serão detalhados os fatores identificados pelos dois autores citados acima:

Resultados militares favoráveis com a utilização do processo logístico - A logística militar mostrou como a distribuição de suprimentos pode ser realizada de maneira a obter melhores resultados nas suas operações.

Utilização de novas tecnologias - O uso de novas tecnologias, como computadores e programas computacionais gerenciais, proporcionavam o processamento das informações necessárias para um gerenciamento eficaz. Bowersox (1969) identifica a tecnologia como a "fertilidade" da logística. O avanço tecnológico possibilitou o gerenciamento de forma integrada, devido a sua capacidade transmissão e armazenamento de informações relacionadas tanto aos processos logísticos como aos processos de outras áreas.

* Ambiente econômico instável - "Houve crescimento econômico substancial após a segunda guerra, seguido de uma recessão e um período de prolongada pressão nos lucros” (BALLOU, 1993, p. 31). Esse cenário de recessão, após o crescimento pósguerra, favoreceu ao desenvolvimento de processos gerenciais que auxiliassem a redução dos custos e melhora na qualidade nos serviços oferecidos aos clientes, dentre esses podemos destacar a logística.

Alterações nos padrões e atitudes da demanda do consumidor - Nos Estados Unidos houve substancial mudança no número de centros comerciais, como também, houve mudança das regiões onde a população passou a residir (BALLOU, 1993, p.31). Além disso, a população demandava variedade nos produtos oferecidos, e ainda, diversidade na tipologia dos produtos, por exemplo, cores diferentes. Essas situações levam a níveis de estoque mais altos, por conseguinte, os seus custos também aumentam. Esse 
cenário exigia o desenvolvimento de processos gerenciais que reduzissem os custos das operações, como transporte e estocagem.

Nesse clima de desenvolvimento do processo logístico, em 1956, já foi possível reconhecer indícios do conceito de gerenciamento integrado no trabalho The Hole of Air Freight in Phisical Distribution, cujos autores são Lewis, Culliton, Steele (BOWERSOX, 1969). O trabalho introduz o conceito de custo total para a área da logística, a partir da justificativa da escolha do transporte aéreo, esse com alto custo de transporte, devido à economia em outros processos da logística, como redução do inventário de posse da empresa e estocagem de suprimentos.

Os anos pós-guerra são marcados pelo início de um próspero desenvolvimento logístico diante de cenários social, econômico e tecnológico favoráveis. O que já era observado desde o início do século vinte, a necessidade de análise da distribuição física, começou a ser estudado de forma mais intensa. Os conceitos de integração e análise do custo total são exemplos desses estudos. Nos anos seguintes, esses conceitos evoluíram, e, outros conceitos foram incorporados à logística.

\section{$\underline{1960-1969}$}

Os anos sessenta foram marcados pelo intenso desenvolvimento dos processos da gestão da logística. Nesse período houve a aplicação da teoria de sistemas nas operações logísticas, como também, o seu desenvolvimento acadêmico e profissional.

Em 1961, houve a publicação de um dos primeiros textos sobre a aplicação da Teoria de Sistema $^{16}$ no processo logístico, Physical Distribution Management, cujos autores são Smykay, Bowersox e Mossman (LAMBERT; STOCK, 1993). Ainda, Bowersox (1969) relata sobre a publicação de artigos do início dos anos sessenta que incorporam aplicação da Teoria de Sistemas na logística.

\footnotetext{
16 "Sistema é um conjunto de partes que interagem entre si para funcionarem como um todo" (KAUFFMAN Jr.1980. P.6). A teoria de sistema envolve a interação das partes presentes em um projeto com a fim de atender os objetivos do projeto.
} 
A Teoria de Sistemas no cenário da logística consiste em integrar os diversos setores da empresa - como produção, marketing, finanças - ao processo logístico. As decisões tomadas em um determinado setor podem interferir em outro, como também, pode haver diferenças de interesses entre os setores. Essa diferença de interesses é evidenciada quando o setor de produção deseja maiores prazos para processamento do produto final com o menor custo possível, enquanto o setor de marketing deseja atender ao cliente no menor prazo possível. Em uma situação como essa, a integração resulta no equilíbrio dos desejos tanto do setor de produção, como do marketing, por exemplo. A aplicação da teoria de sistemas integra os diversos setores da empresa, com a finalidade de equilibrar os interesses divergentes, e obter os melhores resultados em relação ao produto entregue ao cliente.

Nos anos sessenta é possível identificar o surgimento de cursos de graduação e pós-graduação relacionados à logística em Michigan State University e em Ohio State University, como também a publicações de vários textos sobre os processos logísticos. Em 1963 foi criada a primeira organização que reúne profissionais da logística com o propósito de educação e treinamento, chamada de National Council of Physical Distribution (LAMBERT; STOCK, 1993).

Adiante consta um trecho do artigo do Bowersox (1969) que descreve a situação da logística no ano da sua publicação. Nos anos anteriores, as produções acadêmicas da logística estavam, na maioria dos casos, interligadas ao marketing. Esse cenário muda a partir da década de sessenta, com o desenvolvimento acadêmico e profissional da logística.

\footnotetext{
“Os anos desde 1965 foram caracterizados pelo refinamento de conceitos básicos e desenvolvimento de uma melhor precisão nas ferramentas de análise. Enquanto que 1961 viu o primeiro livro devotado para o assunto da distribuição física, hoje uma grande variedade de texto sobre o assunto está disponível. Atualmente, quatro jornais acadêmicos são exclusivamente devotados à aplicação prática da distribuição física, e artigos freqüentemente aparecem em jornais acadêmicos de assuntos relacionados. A área é representada por uma sociedade profissional ativa, o National Council of Physical Distribution. O curso de distribuição física tem sido oferecido comumente em escolas de negócios relacionadas” (BOWERSOX, 1969, p. 65).
}

“O período entre o início dos anos 50 até a década de 60 representa a época de decolagem para a teoria e prática da logística” (BALLOU, 1993, p.29). E as causas desse 
desenvolvimento são as mesmas citadas anteriormente ${ }^{17}$, ou seja, as empresas continuam a exigir a redução dos custos e maiores margens de lucro, as adequações com a demanda são constantes e a tecnologia a cada período evolui intensamente.

A partir dessa evolução dos conceitos, Bowersox (1969) definiu logística, nessa época chamada de distribuição física, como a responsabilidade de projetar e administrar um sistema incorporado de controle do fluxo de materiais a serem processados e inventários acabados. A definição permite identificar os conceitos de integração e teoria de sistemas já incorporados à logística, pois o gerenciamento do fluxo de materiais em processamento e inventários envolve a integração dos processos relacionados ao fluxo, como também, a interligação entre os setores relacionados com o processo logístico. Ainda é possível identificar a evolução diante do conceito de gerenciar não só a fluxo do material acabado, como também o fluxo de materiais em processamento.

Conforme visto, o período entre 1960 e 1969 foi marcado pelo crescimento do conhecimento sobre a gestão da logística. A Teoria de Sistemas foi incorporada, com o objetivo de integrar os setores relacionados às operações logísticas. Houve, também, o surgimento de cursos universitários em escolas de negócios, criação de jornais acadêmicos e conselho relacionado, isto é, uma demonstração do crescimento da logística como processo gerencial. Nos próximos anos esse crescimento perdura, e, também os conceitos já adquiridos amadurecem.

\section{$\underline{1970-1989}$}

O período entre 1970 e 1989 foi marcado pelo estabelecimento dos conceitos adquiridos até o momento, e, desde início desses anos, algumas empresas estavam começando a ter benefícios com o uso da logística (BALLOU, 1993). Pode-se supor que os bons resultados do processo logístico, tanto com os militares e depois com as empresas, principalmente manufatureiras nos anos sessenta, permitiram a disseminação dos seus conceitos. Os conceitos fundamentais integração, aplicação da Teoria de Sistemas, satisfação do cliente - se firmaram, e, também

\footnotetext{
${ }^{17}$ Como indicado nos anos pós-guerra as causas do desenvolvimento logístico são resultados militares favoráveis a partir da utilização do processo logístico, utilização de novas tecnologias, ambiente econômico instável, alterações nos padrões e atitudes da demanda do consumidor.
} 
evoluíram para se adequar às novas exigências do ambiente em que a empresas estavam inseridas.

Mesmo com o desenvolvimento intelectual e acadêmico da logística nos anos anteriores, Ballou (1993) indica que a aceitação do processo logístico pelas empresas ocorria de forma vagarosa. Contudo, no início dos anos setenta essa situação modificou-se, e um dos motivos foi a crise do petróleo. O aumento dos preços do petróleo afetou diretamente os custos do processo logístico, principalmente com relação ao transporte. “Com o acréscimo dos custos de energia durante nos anos setenta, a logística recebeu mais atenção como agente controlador de custo” (LAMBERT; STOCK; ELLRAM. 1998. p. 6). Percebeu-se a capacidade da logística de gerenciar o fluxo de insumos, com o objetivo de resultados eficazes e eficientes com relação custo, prazo e qualidade.

Outro fator da disseminação da logística nas empresas foi o aumento da competitividade (LAMBERT; STOCK; ELLRAM. 1998). A competição mundial começou a crescer, pois as empresas começaram a buscar mercados diferentes dos seus originais. Com isso aumentaram as demanda por processos gerenciais capazes de atender as necessidades desse novo mercado. “Controle de custos, produtividade e controle de qualidade passaram a ser áreas de interesse, à medida que as empresas tentavam enfrentar o fluxo de mercadorias importadas” (BALLOU, RONALD H.1993. 35p).

Nesse mesmo período a Tecnologia de Informação ${ }^{18}$ (TI) teve um intenso desenvolvimento. "Isso melhorou a habilidade da organização de monitorar atividades com intensas transações, como pedidos, movimentação e estocagem de insumos” (LAMBERT; STOCK; ELLRAM, 1998, p.6). A TI facilitou o processo logístico devido a sua capacidade de armazenamento, processamento e transmissão das informações, com qualidade e prazo desejáveis na execução das operações.

Até antes dos anos setenta a determinação da seqüência de trabalho realmente eficiente e com resultados eficazes era um problema para os pesquisadores da área, contudo, a partir dessa época, começaram a surgir programas computacionais capazes de realizar essa tarefa (ORLICKY, 1975, p.7). Esses softwares facilitaram a programação de processos de produtivos complexos com a integração de diversos setores da empresa, ou seja, foi possível

${ }_{18}$ Tecnologia de informação refere-se às tecnologias de transmissão, armazenamento e processamento de informações. 
articular uma seqüência lógica de trabalho considerando os diversos setores da empresa como produção, finanças e marketing.

Apesar de, desde os primórdios, a gestão da logística estar ligada ao marketing, apenas a partir dos anos setenta foi dada a devida atenção ao nível de serviço oferecido ao cliente. O período dos anos setenta até primeira metade dos anos oitenta pode ser denominado como a era focada no cliente (KENT Jr.; FLINT, 1997). O serviço oferecido ao cliente tornou-se uma importante consideração nas operações logísticas. O papel da empresa era equilibrar a satisfação do cliente com os custos das operações logísticas, ou seja, era atender as exigências do cliente com o menor custo total possível. Nesse ambiente de competitividade, a qualidade do serviço oferecido tornou-se um fator fundamental na elaboração de estratégias para manter seus clientes e adquirirem novos.

Nesses anos também houve a consolidação do conceito de integração, que nesse período foi denominada de “integração interna”. A integração interna é a consolidação do conceito já inserido à logística de integração entre os setores. Essa integração envolve o gerenciamento em conjunto dos processos relacionados ao fluxo de insumos dentro da organização, como também os sistemas de controle e fluxo de informações (MASTERS; POHLEN, 1994).

Entre os anos de 1970 e 1989 houve a consolidação da logística como processo gerencial do fluxo de insumos dentro da organização. As empresas, diante dos cenários econômico, mercadológico e tecnológico, enxergaram a logística como um recurso de estratégia competitiva. Os conceitos de satisfação do cliente e integração interna foram consolidados dentro das operações logísticas.

\section{$\underline{\text { Anos 1990-2007 }}$}

Conforme visto, desde a década de setenta as empresas se interessavam pelos mercados internacionais, contudo apenas nos anos noventa houve um crescente desenvolvimento dessa internacionalização, em conseqüência, o aumento da competitividade (MASTERS; POHLEN, 1994; CHRISTOPHER, 1997). Com o crescimento de sua área de atuação, as empresas introduziram processos gerenciais capazes de melhorar a competitividade nesse mercado tão acirrado. 
Nesse cenário de globalização, o conceito da logística evoluiu. Antes de 1945 o gerenciamento era realizado de forma fragmentada, segundo relato anterior. Depois da Segunda Guerra Mundial, o conceito de integração foi incorporado à logística, com a consolidação da "integração interna” nos anos oitenta. Agora, nos anos noventa, com a globalização, o conceito de integração evoluiu, ou seja, houve a necessidade da integração externa. A Figura 8 mostra essa evolução do conceito da forma de gerenciar o processo logístico.

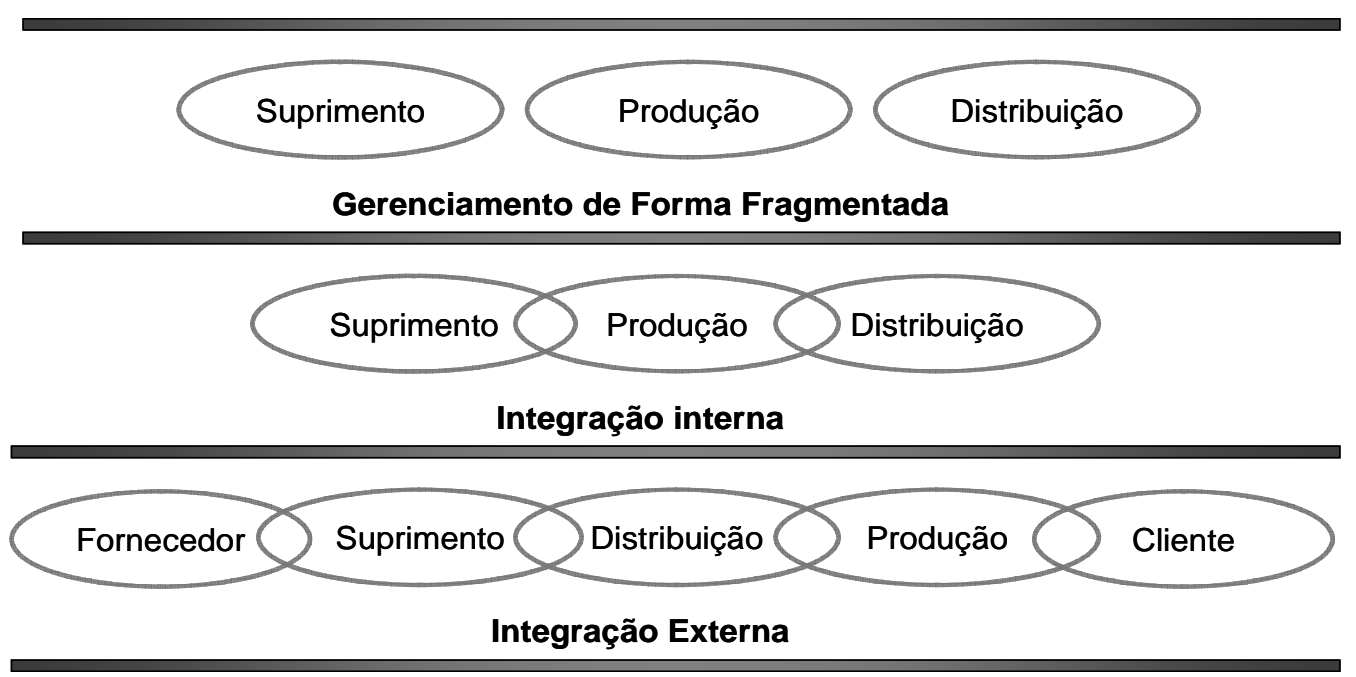

Figura 8 - Evolução da Estrutura de Gerenciamento da Gestão da Logística Fonte: Adaptado pela autora a partir de Christopher (1997)

A integração externa abrange a integração do fornecedor de suprimentos e do cliente ao processo do fluxo de insumos dentro da organização. Isto é, as necessidades e restrições tanto dos fornecedores, como dos clientes, são analisadas no processo logístico.

Essa integração externa veio da necessidade da redução de custos e da redução dos riscos no fluxo de insumos (MASTERS; POHLEN, 1994). A redução dos custos ocorre devido ao melhor entendimento do seu comportamento ao longo do fluxo de processamento de insumos, e com isso, identificar onde é possível reduzir os custos, como também, onde é possível melhorar a produtividade. A redução de risco ocorre devido ao conhecimento das demandas do processo por parte dos integrantes que compõem o fluxo de insumos, e com isso, existe a eliminação de re-trabalhos e atrasos, como também, custos que podem ser compartilhados entre as empresas, por exemplo, custos de propaganda. 
Vale aqui fazer um comentário quando a denominação do processo logístico a partir da integração externa. Com a evolução do conceito de integração externa, a cadeia que engloba o fornecedor, o cliente e o gerenciamento do fluxo de insumos dentro da empresa, passou a se chamar "Cadeia de Suprimento". E todo processo de planejamento, de efetivação e de controle do fluxo de insumos desde os fornecedores até o cliente final é chamado de gerenciamento da cadeia de suprimentos. A definição da cadeia de suprimentos segundo o Council of Supply Chain Management Professional, chamando anteriormente Council of Logistic Management é:

\footnotetext{
"Gerenciamento da Cadeia de Suprimento abrange o planejamento e o gerenciamento de todas as atividades envolvidas na procura e na obtenção, conversão, e todas as atividades do gerenciamento da logística. Importante, também incluir a coordenação e a colaboração com os sócios da cadeia, que podem ser fornecedores, intermediadores, fornecedores de serviço, e clientes.”. ${ }^{19}$
}

No final dos anos noventa e início dos anos 2000, um novo conceito é introduzido no processo logístico - logística reversa - ou seja, a área da logística empresarial que planeja, opera e controla o fluxo de informações logísticas correspondentes, do retorno dos bens de pós-venda e de pós-consumo ao ciclo de negócios ou ao ciclo produtivo, por meios de canais de distribuição reversos, agregando-lhes valor de diversas naturezas: econômico, ecológico, legal, logístico, de imagem corporativa, entre outros (LEITE, 2003).

Para melhor entendimento da logística reversa a Figura 9 mostra o fluxo dos insumos tanto no canal logístico reverso como no canal direto.

\footnotetext{
${ }^{19}$ Definição Council of Supply Chain Management Professional. Disponível em: http://www.cscmp.org/. Acesso em: setembro 2006. Glossário com a definição atualizado em fevereiro de 2005.
} 


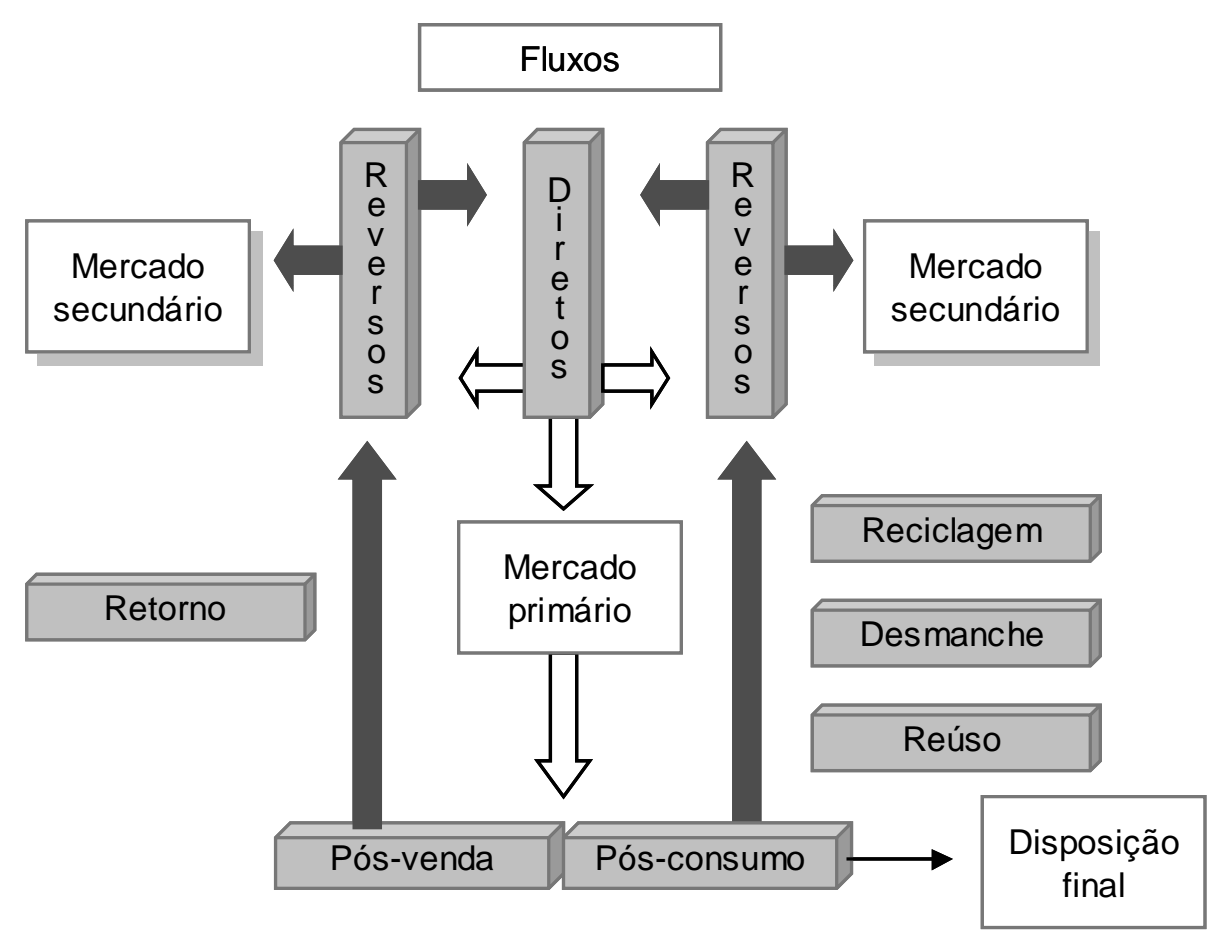

Figura 9 - Canais de distribuição - direto e reverso Fonte: Leite (1999), apud Leite (2003)

A logística reversa trata do gerenciamento do fluxo de insumos pós-venda ou pós-consumo e informações relacionadas. Os insumos pós-venda constituem a parcela de insumo que retornam a partir do consumidor, devido a defeitos ou mesmo erro no pedido, e seguem para um mercado secundário, ou mesmo retornam para o mercado primário, por meio de um canal de distribuição, onde ao final esses insumos possuem um determinado valor. Esse canal de distribuição inicia-se com o consumidor e termina com o mercado secundário ou primário.

Os insumos pós-consumo são originados no descarte dos insumos depois da sua utilização. Esses são originados pelo consumidor, passam por processos como reuso, reciclagem, ou desmanche, e seguem para um mercado secundário ou primário. O canal de distribuição é similar ao canal dos insumos pós-consumo.

A terceira opção é a disposição final com inutilização do insumo restante após o consumo.

Em suma a logística reversa engloba o gerenciamento da disposição dos insumos após o consumo ou a venda. Essa atenção com a disposição dos insumos veio diante do cenário, onde a sociedade em geral preocupava-se com o meio ambiente. "A sociedade, em todas as partes 
do globo, tem se preocupado cada vez mais com os diversos aspectos do equilíbrio ecológico” (LEITE, 2003, p.20). A população passou a pensar nas conseqüências dos prejuízos causados ao meio ambiente, e os governantes, passaram a regulamentar e efetivar leis de controle ambiental. Em conseqüência, empresas passaram a se preocupar com a disposição dos seus resíduos.

Como também as empresas passaram a se preocupar com a imagem corporativa, ou seja, as empresas estão preocupadas com a ética social e meio ambiente. Essa imagem pode constituir uma vantagem competitiva para ela. E ainda, é possível observar no canal reverso vantagem econômica, no sentido de que o insumo que seria inutilizado, agora no canal reverso, ele adquiri valor econômico, e é vendido para um mercado secundário.

Diante desse cenário, o conceito de logística reversa foi introduzido à logística, devido às preocupações da sociedade em geral com o meio ambiente, vantagem competitiva de uma imagem corporativa e ao ganho de valor do insumo no canal reverso.

Conforme visto na evolução histórica, desde o início do século passado os conceitos logísticos mudaram e amadurecem ao longo dos anos, foram incorporados às mais diversas organizações para atender às exigências do mercado. A logística, atualmente, faz parte da cadeia de suprimentos com o gerenciamento do fluxo de insumos dentro da organização. Nesse sentido, o Council of Supply Chain Management Professional define logística como:

“é parte do gerenciamento da cadeia de suprimento que planeja, implementa, e controla a eficácia e eficiência do fluxo normal e reverso de bens, serviços e informação relativa entre o ponto de origem e ponto de consumo a fim de atender os requerimentos do cliente. ${ }^{20}$

Essa é uma definição para a logística voltada para o âmbito da produção. Contudo o foco desse trabalho é o estudo da logística com a finalidade de auxiliar o gerenciamento dos empreendimentos da construção civil na sua fase de implantação, focado em empreendimentos hoteleiros. Para isso, todos os conceitos exposto incorporados à logística integração, visão sistêmica, satisfação do cliente - também devem ser avaliados quanto a sua aplicação ao gerenciamento do fluxo de insumos nos empreendimentos da construção civil.

\footnotetext{
${ }^{20}$ Definição Council of Supply Chain Management Professional. Disponível em: http://www.cscmp.org/. Acesso em: setembro 2006. Glossário com a definição atualizado em fevereiro de 2005.
} 
Diante dos conceitos identificados incorporados à logística, e, diante da consideração do foco do presente trabalho, a gestão da logística é definida conforme o quadro a baixo.

Gestão da Logística é o gerenciamento do fluxo de insumos e informações relacionadas, a fim de auxiliar a atender os requisitos de um projeto. A gestão da logística planeja, executa e controla o fluxo de insumos necessários para a consecução do projeto.

A gestão da logística é um dos conjuntos de processos do gerenciamento do suprimento, que provêem o insumo no tempo, qualidade e desempenho requerido. Prover o insumo no tempo requerido envolve a sua entrega em um prazo aceitável para o cliente, diante das suas necessidades de utilização desse mesmo insumo. A gestão da logística, juntamente com os outros processos do gerenciamento do suprimento, auxilia a atingir as expectativas de qualidade de um projeto.

\subsection{GESTÃO DA LOGÍSTICA INTEGRADA AOS PROCESSOS DO GERENCIAMENTO DE PROJETOS}

Caron e Fiore (1995) integraram os processos de gestão da logística ao gerenciamento de projetos com a finalidade de evitar atrasos e aumento dos custos do projeto. Enquanto que Yeo e Ning (2002) integraram o gerenciamento de projetos ao gerenciamento da cadeia de suprimento com a mesma finalidade de evitar atrasos e aumento dos custos. Já Caron, Marchet e Perego (1998) integraram o gerenciamento do suprimento com a logística, com o objetivo de evitar interrupções no projeto devido a falta de insumo e com isso ocorrer atrasos. Essas pesquisas visam integrar os processos da logística aos processos do gerenciamento de projetos, devido a capacidade processos logísticos em coordenar o suprimento de insumos conforme a baseline $e^{21}$, durante a execução do projeto.

Caron e Fiore (1995) integram a logística aos processos do gerenciamento de projetos em projetos de produção de equipamentos de alta tecnologia, com a finalidade de reduzir os prazos de produção, e ainda devido possibilidade de flexibilizar o projeto a partir da interface dos processos da logística com a produção. O estudo de Caron, Marchet e Perego (1998)

\footnotetext{
${ }^{21} \mathrm{O}$ baseline refere-se ao planejamento inicial no projeto. Ao longo do projeto, a depender das necessidades, o baseline pode ser alterado.
} 
elaborou um modelo que integra a programação das atividades (fase de construção) e com a programação de entrega dos insumos (fase de suprimento) na implantação de empreendimentos. Esse modelo analisa as curvas $S^{22}$ de execução das fases do projeto (engenharia, suprimento e construção) e mostra uma defasagem em relação ao tempo de execução de cada uma dessas curvas. E ao reconhecer o tempo de cada uma dessas curvas S, possibilita identificar o tempo da aquisição de insumos para o empreendimento. A análise dessas curvas ocorre durante o planejamento do empreendimento.

O estudo de Yeo e Ning (2002) integra a cadeia de suprimento ao caminho critico do empreendimento. O estudo analisa o suprimento do empreendimento diante das restrições de prazo das atividades do caminho critico do projeto. Essa análise deve ocorrer primeiramente no planejamento do empreendimento e ser reavaliada ao longo da sua execução.

Todos esses estudos visam auxiliar no atendimento das exigências da implantação de projetos, com a introdução dos conceitos da logística ao gerenciamento de projetos. Os processos logísticos são integrados ao conjunto de processos do gerenciamento de projetos, mais especificamente ao conjunto de processos do gerenciamento de suprimento.

O gerenciamento de projetos é usualmente composto por grupos de processos bem definidos que interagem entre si durante a realização do projeto. São identificados como grupos de processos de iniciação, planejamento, execução e encerramento (PMI, 2004, p.38). Eles são desdobrados em nove áreas de conhecimento do gerenciamento de projetos (integração, escopo, prazo, custo, qualidade, recursos humanos, comunicação, risco e suprimento)

Dentre as áreas de conhecimento do gerenciamento de projetos, o gerenciamento do suprimento (project procurement management) envolve os processos de compra ou aquisição de produtos, serviços ou resultados fora do time de projeto para executar o trabalho (PMI, 2004, p.269). Esse conjunto de processos são responsáveis por suprir os projetos com insumos requeridos.

O gerenciamento do suprimento é composto pelos os seguintes processos (PMI, 2004, p.269):

\footnotetext{
${ }^{22}$ Curva S refere-se à representação gráfica acumulativa de custos ou quantidade de um determinado item empregado em um projeto, indicando a sua evolução ao longo do tempo. O nome se origina do formato parecido com S da curva (mais plana no início e no final, e mais inclinada no centro) gerada para representar um projeto que começa lentamente, se agiliza e em seguida diminui o ritmo (PMI, 2004, p.357)
} 
Planejar compras e aquisições - determinação do que comprar ou adquirir, quando e como fazer isso;

Planejar contratações - documentação dos requisitos de produtos, serviços e resultados, e identificação de possíveis fornecedores;

Solicitar respostas de fornecedores - obtenção de informações, cotações, preços, ofertas ou propostas, conforme adequado;

Selecionar fornecedores - análise de ofertas e escolha entre possíveis fornecedores e negociação de um contrato por escrito para cada fornecedor;

Administração de contrato - gerenciamento do contrato e da relação entre o comprador e fornecedor, análise e documentação do desempenho atual ou passado de um fornecedor a fim de estabelecer ações corretivas necessárias e fornecer uma base para futuras relações com o fornecedor, gerenciamento de mudanças relacionadas ao contrato e, quando adequado, gerenciamento da relação contratual com o comprador externo do projeto.

Encerramento do contrato - terminar e liquidar cada contrato, inclusive a resolução de quaisquer itens em aberto, e encerrar cada contrato aplicável ao projeto ou a uma fase de projeto.

Conforme visto o gerenciamento de suprimento, segundo PMI (2004), é responsável por suprir o empreendimento conforme as diretrizes especificadas pelos processos de planejamento (planejar compras e aquisições e planejar contratações). Além disso, os processos de suprimentos abrangem a seleção e contração de fornecedores e gerenciamento dos contratos.

Contudo, diante das definições dos processos do gerenciamento do suprimento relacionadas pelo PMI (2004), nada é relatado sobre o equacionamento da disponibilidade do insumo com as necessidades do projeto, como também não é analisada de forma direta a coordenação do fluxo de insumos. 
Suprir o empreendimento conforme um determinado planejamento também busca compatibilizar os processos do ciclo de implantação com as condições de fornecimento. Ou seja, esse equacionamento busca o monitoramento das condições de fornecimento dos insumos, para com essa informação identificarem as necessidades de transporte, condições de armazenagem e processos de implantação, a fim de atender à baseline do projeto.

Diante dessa necessidade de compatibilizar os processos do ciclo de implantação com as condições de fornecimento, os processos da logística são integrados aos processos do gerenciamento de suprimento. A gestão da logística estuda como melhorar os resultados da distribuição de insumos através do planejamento, organização e controle efetivos para as atividades de movimentação e armazenagem que visam facilitar o fluxo dos insumos (BALLOU, 1993).

A integração da gestão da logística aos processos do gerenciamento do suprimento na implantação de empreendimentos busca melhorar as condições de atendimento dos requisitos de escopo, prazo, custo e qualidade devido a sua capacidade de gerenciamento do fluxo de insumos.

Diante dos conceitos apresentados, a seguir, são analisados os processos logísticos a partir da ótica da implantação de empreendimentos.

\subsubsection{LOGÍSTICA NO CICLO DE IMPLANTAÇÃO DE EMPREENDIMENTOS}

O ciclo de implantação de empreendimentos contempla a aquisição, fornecimento e instalação de uma gama de insumos. Cabe a gestão da logística gerenciar o fluxo de insumos desde o momento de aquisição até a sua utilização.

A utilização da logística na implantação de empreendimentos da construção civil foi estudada por diversos autores. Cruz, Rodrigues e Novaes (1998) propuseram um modelo logístico para a construção civil. Esse modelo gerencial proporciona uma abordagem sistêmica aos processos de fornecimento de insumos durante a implantação de empreendimentos da construção civil, em conseqüência o modelo integra as necessidades do cliente, da empresa e dos fornecedores. 
Além desse estudo, Silva (2000) propões diretrizes para a logística em empresas construtoras de edifícios. Esse estudo analisa a logística no cenário da implantação de edifícios a partir da integração da logística à produção do empreendimento, com o objetivo de aumentar a racionalização dos processos de produção e competitividade do empreendimento.

A logística na implantação de empreendimentos tem o papel fundamental de integrar os fluxos de insumos fornecidos com os processos de execução do empreendimento. Isso abrange tanto aspectos relacionados a prazos, custo e qualidade dos insumos fornecidos, como também em relação à gestão da capacidade de estoque no canteiro e junto aos fornecedores.

Segundo Silva (2000, p.20) a logística é um processo multidisciplinar inserido no processo produtivo de um ou mais empreendimentos que visa garantir:

* a disponibilização destes recursos nas frentes de trabalho;

* a armazenagem de matérias-primas e bens processados, quando necessário;

* o fluxo e a seqüência das atividades de produção;

* a gestão das informações relacionadas aos fluxos físicos de produção;

Como também, "não se pode pensar em sistema logístico racionalizado sem considerar todos os agentes que intervêm nesse processo e sem fazer com que estes tenham acesso aos canais eficazes de comunicação, que permitam que a informação circule de maneira contínua, com qualidade” (VILLAGÁRCIA ZEGARRA, 2000, p.4).

O dimensionamento de recursos é realizado por um processo de planejamento que contempla a definição do escopo, prazo, custo e qualidade de fornecimento. Esse planejamento elabora as diretrizes para a disponibilização dos recursos, armazenagem dos insumos quando necessária, e fluxo e seqüências das atividades. Para a execução dessas atividades, as informações devem estar disponíveis no tempo necessário através de um sistema de informação estruturado segundo a hierarquia decisória do processo de gestão do suprimento do empreendimento.

Além disso, a integração do time do projeto com os dos fornecedores é necessária. Isatto (1996) estudou sobre o relacionamento com os fornecedores do empreendimento, onde é 
incentivado um relacionamento de parceria para atender as necessidades tanto do empreendimento como do fornecedor. Essa integração possibilita melhores prazos de entrega, como também possibilidade a análise do just-in-time, já que estocar os insumos requer espaços que nem sempre estão disponíveis nas obras.

A partir da definição das diretrizes do planejamento ocorre a execução do fluxo de insumos que abrange transporte, armazenagem e disponibilização dos insumos nos locais de utilização. A partir da execução é possível coletar as informações de como o processo foi realizado e, assim, analisar comparativamente as diretrizes iniciais e o realizado. Essa análise embasa a verificação para a necessidade de re-planejamentos, a partir do processo de controle.

As considerações anteriores permitem esse trabalho considerar que os processos logísticos são compostos por:

Elaboração do planejamento logístico, com relação insumos versus os requisitos de prazo, custo e qualidade;

Gerenciamento das comunicações relacionadas ao fluxo de insumos;

Execução das operações logísticas - transporte, armazenagem e disponibilização dos insumos nos locais de utilização - e controle.

O processo de planejamento fornece a informação base para a execução da logística. Contudo, para que as operações logísticas sejam realizadas com a qualidade necessária, é preciso dispor de um gerenciamento da comunicação eficiente, pois o planejamento logístico é baseado no planejamento geral ${ }^{23}$ do empreendimento. Além disso, no gerenciamento da comunicação é necessária a integração e visão sistêmica dos processos componentes do projeto. Com a estruturação da baseline, a partir do planejamento logístico, e estruturação da comunicação, a partir do gerenciamento da comunicação, as operações logísticas são realizadas e o processo de controle tem função de informar as discrepâncias entre o planejamento e o realizado, e assim haver um re-planejamento se necessário.

\footnotetext{
${ }^{23} \mathrm{O}$ planejamento geral do empreendimento engloba as informações básicas de escopo, prazo, custos e qualidade do empreendimento.
} 
Diante da identificação dos processos logísticos, é possível estruturar esses processos integrados aos processos do gerenciamento de projetos, conforme a figura a seguir.

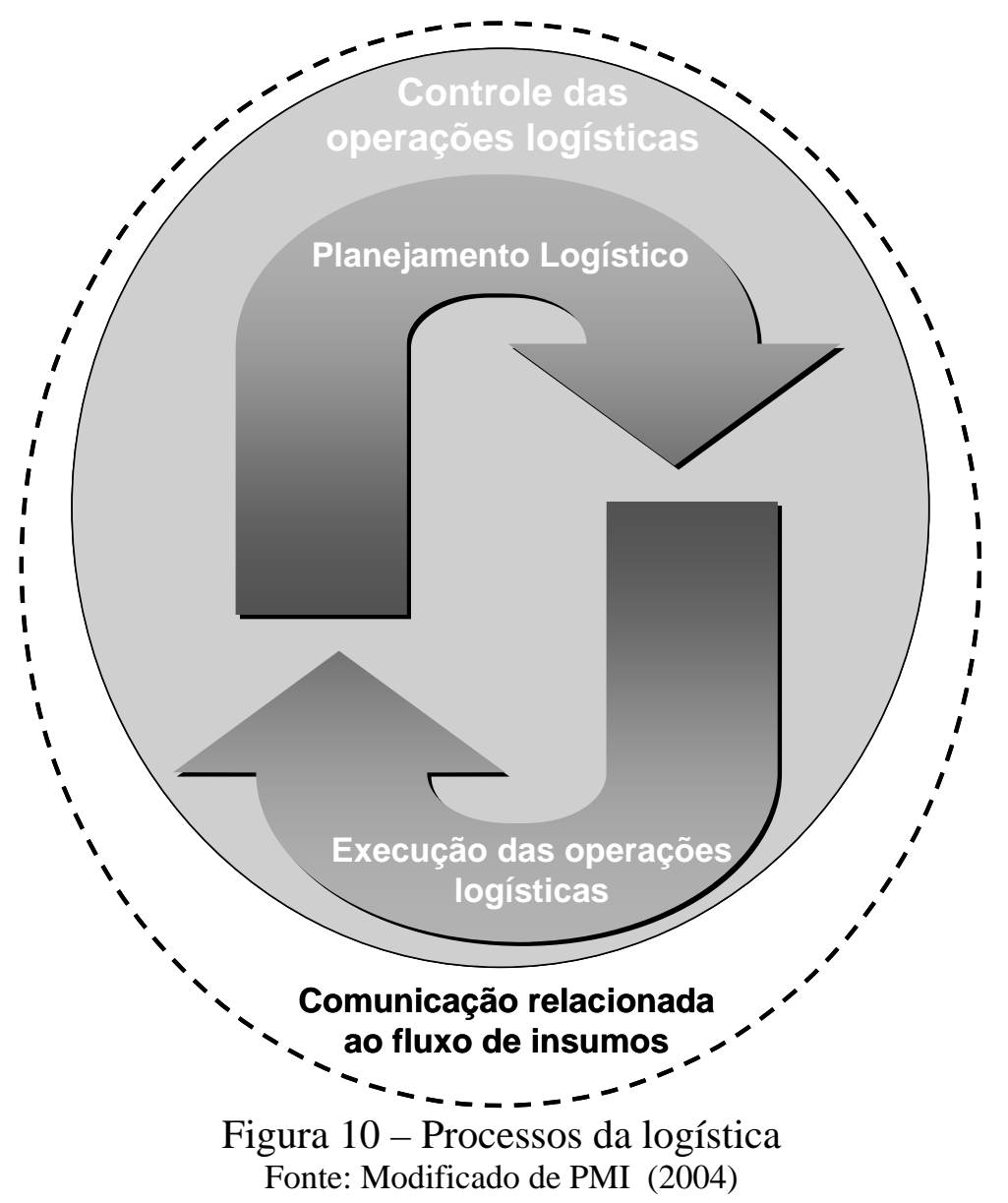

O gerenciamento desses processos requer o uso de ferramentas que auxiliem a sua efetivação de maneira eficiente e eficaz. Ao longo dos anos várias classes de ferramentas foram elaboradas, como o MRP (Materials Requirements Planning) e MRPII (Manufacturing Resource Planning). Atualmente existe o ERP (Enterprise Resource Planning).

O sistema ERP é constituído de módulos gerenciais interligados, que integram os diversos setores da empresa como produção, finanças, contabilidade (BEHESHTI, 2006). O objetivo desse sistema é fornecer a informação gerencial necessária para a tomada de decisão em tempo hábil e com qualidade compatível aos requisitos da empresa. O ERP armazena em um único banco de dados o fluxo de informação de todo o projeto, dessa maneira é possível disponibilizar as informações necessárias para a tomada de decisão. A evolução do sistema ERP, o sistema ERP II, incorpora os conceitos logísticos de integração com os clientes e fornecedores. 
As operações logísticas de transporte, armazenamento e disponibilização dos insumos são efetivadas com auxilio desse sistema, ou outro sistema que se ajuste à organização, portanto que contenham o conceito de integração dos stakeholders aos processos logísticos. “A concepção logística de agrupar conjuntamente as atividades relacionadas ao fluxo de produtos e serviços para administrá-las de forma coletiva é uma evolução natural do pensamento administrativo" (BALLOU, 1993, p.18).

A crescente ênfase de recursos suportados por tecnologia de informação e novas ferramentas computacionais aumentam as possibilidades da integração dos processos e gerenciamento sistêmico, e para os processos logísticos a integração e gerenciamento sistêmico são conceitos fundamentais.

A evolução dos conceitos logísticos permitiu reconhecer que, juntamente com realização dos processos no empreendimento, é necessária a integração tanto dos processos internos ao empreendimento, como dos processos externos. A realização dos processos de maneira individualizada oferece um ambiente propício para a desorganização no empreendimento. “A convicção de que um desempenho integrado produz melhores resultados que funções gerenciais individualizadas, sem coordenação entre si, constitui o paradigma fundamental da logística” (BOWERSOX, 2001, p. 36).

Esse conceito de integração se estende de forma recíproca até o fornecedor. As condições de fornecimento, em relação ao prazo, escopo e custo, devem ser identificadas, e então equacionar os processos produtivos a essas condições de fornecimento. Com isso, essa compatibilização reduz a possibilidade de atrasos na entrega do suprimento. E caso houver algum imprevisto, as informações podem e devem ser passadas antecipadamente de modo a possibilitar re-planejamentos que mitiguem essas distorções.

Além da integração entre os processos da logística, também existe a integração do conjunto dos processos logísticos com as demais áreas de gerenciamento do empreendimento, como o gerenciamento de tempo e gerenciamento de risco. Essa integração prove uma visão sistêmica dos processos que abrangem o projeto.

Atingir o nível de integração dos processos, tanto a integração entre os processos logísticos como a integração do conjunto de processos com os demais processos de gerenciamento, está intimamente ligada a comunicação do time de projeto com fornecedores e stakeholders ao 
longo da realização dos processos. No processo de planejamento, existe a comunicação entre os indivíduos do time de projeto, como também a comunicação desse time com as áreas de gerenciamento do empreendimento, e ainda com os fornecedores e stakeholders. Nos processos de execução e controle, a comunicação deve ocorrer de maneira similar ao processo de planejamento, e ainda, se os times de planejamento e controle forem diferentes deve existir a comunicação entre esses times. É possível afirmar que a eficiência da logística é influenciada pela sua capacidade de comunicação.

Diante do cenário exposto quanto aos processos logísticos e suas interfaces com os processos de gerenciamento, serão analisados a seguir em detalhes os processos logísticos [1] planejamento logístico, [2] gerenciamento das comunicações, [3] execução das operações logísticas e controle logístico.

\subsubsection{PLANEJAMENTO LOGÍSTICO}

O planejamento logístico possui o objetivo de elaborar as diretrizes para a execução das operações logísticas ao longo do ciclo de vida do empreendimento. Essa etapa identifica o escopo, prazo, custo e padrão de qualidade para a execução das operações logísticas.

O planejamento logístico identifica de forma estruturada as informações necessárias para a disponibilização do insumo. Ou seja, o processo trata da identificação dos insumos requeridos na realização das tarefas, suas quantidades, prazos requeridos, custos e suas especificações ${ }^{24}$, condições de transporte, armazenagem e disponibilização no local de utilização.

Segundo Cruz, Rodrigues e Novaes (1998) o fluxo logístico em empreendimentos da construção civil envolve um extenso fluxo material desde o fornecedor, incluindo o transporte até o local de produção, passando por uma intensa movimentação interna no canteiro de obra até a chegar ao ponto de aplicação final.

Diante do fluxo de insumos apresentados, o processo de planejamento logístico em empreendimentos é composto pelas seguintes atividades:

\footnotetext{
${ }^{24}$ Quando se fala em especificação do insumo, aqui nesse texto, refere-se às especificações técnicas do insumo.
} 
a) Identificação das demandas de insumos ao longo do ciclo de implantação do empreendimento, segundo uma determinada programação por recursos;

b) Identificação das especificações dos insumos a serem adquiridos;

c) Identificação das condições de fornecimento dos insumos relacionadas aos prazos, custos e qualidade, ou seja, condições para a entrega dos insumos;

d) Identificação das condições de armazenagem dos insumos;

e) Identificação das condições de disponibilização dos insumos no local de uso.

O conjunto dessas atividades tem como objetivo identificar o escopo, prazos, custos e qualidade das operações logísticas de transporte, armazenagem e disponibilização dos insumos no local de uso no empreendimento.

\section{Identificação das demandas de insumos ao longo do ciclo de implantação do empreendimento, segundo uma determinada programação por recursos}

A programação orientada a recursos identifica os prazos em que os insumos são requeridos, juntamente com as suas quantidades ao longo do projeto. Conforme Silva (1999) o processo de programação por recursos envolve:

Identificação dos recursos;

Avaliação da demanda;

* Seleção da solução para designação de recursos.

A seguir as etapas do processo de programação por recursos estão descritas de forma sucinta e estruturadas na Figura 11, e, ainda, podem ser encontradas com maior detalhe em Silva (1999). 


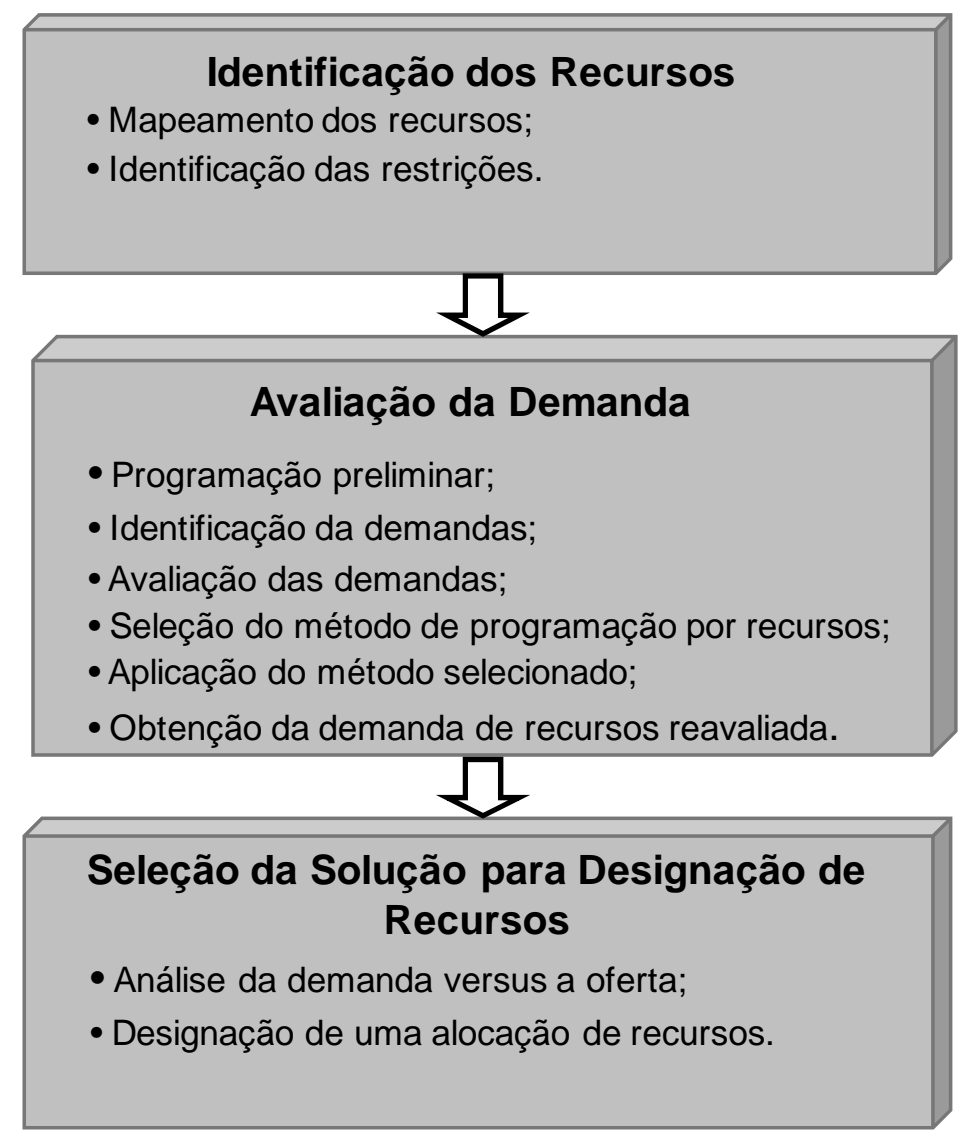

Figura 11 - Processo de programação por recursos Fonte: Adaptado de Silva (1999)

\section{Identificação dos recursos}

Nessa etapa do processo ocorre o mapeamento dos recursos e a identificação das suas restrições. Para a realização dessa fase são necessárias informações preliminares do empreendimento como:

EAP (Estrutura Analítica de Projeto) com a identificação dos pacotes de trabalhos e respectivas atividades necessárias para a realização do empreendimento;

Identificação dos métodos e tecnologias empregados para a realização da atividade;

Prazo total de execução e eventos intermediários;

Orçamento do empreendimento. 
Essa etapa ocorre em duas fases do ciclo de vida do empreendimento. A primeira, no planejamento tático, com a identificação do escopo para a execução do empreendimento versus as tecnologias e metodologias a serem empregadas. A segunda, no planejamento operacional, a partir das informações da EAP em seu nível de maior detalhe. Nas duas situações as atividades a serem realizadas determinam os recursos empregados.

Com o mapeamento dos insumos, existe a possibilidade de identificar as suas restrições. No planejamento tático as restrições ocorrem em linhas gerais, por exemplo, tecnologia ou limitações do projeto. Já no plano operacional, as restrições ocorrem quanto aos requisitos de planejamento do empreendimento de prazo e custo estabelecidos.

\section{Avaliação da demanda}

A fase de avaliação da demanda envolve: [1] programação preliminar, [2] identificação das demandas dos recursos, [3] avaliação das demandas, [4] seleção do método de programação por recursos mais adequada, [5] aplicação do método selecionado; [6] obtenção da demanda de recursos reavaliada (SILVA, 1999).

A fase de programação preliminar envolve a programação das datas do projeto a partir da utilização de ferramentas como o CPM (Critical Path Method). Ballou (1993) relata a aplicação dessa ferramenta nos projetos de construção civil e Silva (1999) indica o CPM como a ferramenta apropriada para as particularidades do setor.

“CPM essencialmente é a representação do planejamento do projeto por um diagrama esquemático ou rede que produzem a seqüência e inter-relação de todas as partes componentes do projeto, e a análise lógica e manipulação dessa rede na determinação da melhor programação para operação” (ANTILL; WOODHEAD, 1990, p.1). O resultado da aplicação dessa ferramenta são simulações que permitem identificar as datas previstas para a execução das atividades. 
Com a identificação das datas cedo e tarde ${ }^{25}$ para a realização dos processos e atividades, é possível identificar as demandas de recursos necessários. Ou seja, é possível identificar a quantidade necessária dos recursos ao longo do tempo.

Aqui cabe uma análise de quais insumos devem ser gerenciados com maior ênfase conforme as operações da logística. Esses devem ser escolhidos conforme a necessidade de análise e/ou conforme a sua importância na execução do empreendimento, por exemplo, os insumos necessários para a operacionalização do hotel ou insumos de atividades do caminho critico do projeto.

A programação preliminar identifica as datas cedo e tarde de cada processo ou atividade da implantação do empreendimento. Com essas informações, juntamente com as informações dos insumos requeridos por essas atividades ou processos, é possível identificar as datas cedo e tarde que os insumos devem ser disponibilizados para a execução da atividade ou processos.

A partir da identificação da demanda por recursos, é possível fazer a avaliação das demandas quanto a disponibilidade desses recursos. Essa análise busca a solução para os pontos de conflitos em relação ao planejamento geral do empreendimento, por exemplo, consumo elevado do recurso ultrapassando a disponibilidade estabelecida no planejamento.

Essa informação embasa a decisão de seleção do método de programação por recursos mais adequada. Caso o prazo seja o fator crítico haverá a programação de recursos com restrição de prazo, e caso o custo seja o fator, haverá a programação com restrição na alocação de recursos.

Nos projetos onde existe a restrição de prazo, a data de finalização do empreendimento é obedecida em primeira instância, além disso, pode haver datas intermediárias a serem obedecidas. As atividades são priorizadas frente à disputa de recursos. O problema a ser solucionado pela programação é o nivelamento dos recursos, ou seja, é evitar ou reduzir as flutuações de consumo ao longo do ciclo de vida do projeto.

\footnotetext{
${ }^{25}$ Como resultado da programação CPM tem-se datas de início cedo e tarde e término cedo e tarde prevista para cada atividade. As datas cedo indicam o tempo mais cedo para a realização da atividade, e, similarmente, as datas tarde indicam o tempo mais tarde para a realização da atividade. A diferença entre o início cedo e tarde ou término cedo e tarde indicam a folga da atividade.
} 
Já nos projetos onde existe a restrição de recursos, a disponibilidade do recurso é obedecida em primeira instância. A quantidade de recurso é priorizada na programação, e o problema a ser solucionado é alocação dos recursos, ou seja, priorizar as atividades frente à disponibilidade de recurso. Os recursos aqui são limitados, e as suas quantidades disponíveis devem ser o guia da programação.

A partir da escolha, ocorre a aplicação do método selecionado, o nivelamento ou alocação. Com o resultado é realizada uma nova análise para a obtenção da demanda de recursos reavaliada. Essa análise consiste em re-programar as situações da demanda dos recursos e verificarem se atendem as exigências de prazo ou custo de forma aceitável diante dos padrões de qualidade do projeto. O processo dessa fase é similar á etapa anterior de avaliação da demanda dos recursos.

Como resultado da Avaliação da Demanda tem-se as demandas dos recursos ao longo das fases do ciclo de vida do empreendimento em períodos predeterminados, considerando as restrições analisadas e padrão de qualidade estabelecido para o empreendimento.

\section{Seleção da solução para designação dos recursos}

Até o presente momento da programação por recursos, os recursos foram tratados segundo a demanda do empreendimento. Contudo, a oferta dos recursos também deve ser analisada no processo. Essa fase envolve a análise dos resultados obtidos na Análise da Demanda versus a capacidade de oferta dos recursos.

A solução para a designação por recursos envolve o equacionamento da relação entre a oferta e demanda, e deve ser tratada como uma análise de risco, com a identificação dos fatores de risco e desenvolvimento de ações para potencializar os resultados do empreendimento. A designação dos recursos finaliza a programação, com a identificação dos insumos, prazos e quantidades requeridos ao longo da execução do projeto, segundo o equacionamento entre a demanda e oferta e insumos.

A programação por recursos identificou as datas e quantidades de disponibilização dos insumos para a sua aplicação no empreendimento. Pode ser dizer que essa é a data final do fluxo dos insumos. O planejamento das demais operações logísticas deve ocorrer embasado nessa programação. 


\section{a) Identificação das especificações dos insumos a serem adquiridos}

As informações de especificação técnica devem estar disponíveis no planejamento geral do empreendimento. Caso algum requisito traga impacto ao planejamento, tal como prazo de mobilização / desmobilização, isto deve ser incorporado à programação por recursos.

b) Identificação das condições de fornecimento dos insumos relacionadas aos prazos, custos e qualidade, ou seja, condições para a entrega dos insumos;

Com a identificação das demandas ao longo do ciclo de vida do empreendimento e especificação técnica, é possível identificar as condições de fornecimento. Ou seja, quando os insumos devem ser contratados para que atendam essa data final conforme o escopo, custo e qualidade planejados. Logo no início do ciclo de implantação do empreendimento devem ser verificados quais os insumos críticos quanto ao fornecimento, que deverão receber atenção especial por parte da gestão de suprimentos, em particular, da gestão da logística.

\section{c) Identificação das condições de armazenagem dos insumos;}

Na seqüência, diante do conhecimento das condições de fornecimento e datas de disponibilização, devem ser analisadas eventuais necessidades e condições de armazenagem. Aqui são analisadas as datas de liberação de disponibilização dos insumos frente as datas de seu uso efetivo, e como compatibilizar essas datas com as condições de estocagem.

\section{d) Identificação das condições de disponibilização dos insumos no local de uso.}

E para finalizar o planejamento, devem ser analisadas as condições de disponibilização dos insumos no local de utilização, com a identificação condições de transporte do local de armazenamento até o local da efetiva utilização. 
Vale ressaltar que ao longo da execução do empreendimento o planejamento será reavaliado, ou mesmo reformulado, quando houver a exigências no cenário de implantação de empreendimentos.

O resultado do planejamento são informações de prazo para seleção, aquisição, fornecimento e entrega dos insumos e as correspondentes especificações de como as entregas destes deverão ocorrer para atender aos requisitos específicos de cada um e de sua articulação aos demais, em particular os sub-sistemas e sistemas componentes. Esse resultado são as informações base para os processos logísticos subseqüentes.

\subsubsection{GERENCIAMENTO DE COMUNICAÇÃO}

Os resultados do planejamento logístico são informações relacionadas a como as operações logísticas deverão ocorrer. A efetivação dessas diretrizes depende de quando e como as informações elaboradas no planejamento são disponibilizadas para o time de projeto.

Diante dessa necessidade, o gerenciamento das comunicações é associado aos processos logísticos, com o objetivo de coordenar as informações relacionadas ao fluxo de insumos, que envolve a coordenação das informações de planejamento e execução das operações logísticas.

Além disso, o conceito do gerenciamento do fluxo de informações relacionadas ao fluxo de insumos já foi incorporado na própria definição da logística. “A transferência e o gerenciamento eletrônico de informações proporcionam oportunidades de redução de despesas logísticas por meio de melhor coordenação, além do aperfeiçoamento dos serviços que podem ser consubstanciados na melhor oferta de informação a clientes” (BOWERSOX, 2001, p.175).

O gerenciamento das comunicações do projeto é a área do conhecimento que emprega os recursos necessários para garantir a geração, coleta, distribuição, armazenamento, recuperação e destinação final das informações sobre o projeto de forma oportuna e adequada (PMI, 2004, p.221). 
O gerenciamento das comunicações do projeto inclui os seguintes processos (PMI, 2004, p.221):

* Planejamento das comunicações: determinação das necessidades de informações e comunicação das partes interessadas no projeto;

* Distribuição das informações: colocação das informações necessárias a disposições das partes interessadas no projeto no momento adequado;

Relatório de desempenho: coleta e distribuição das informações sobre o desempenho. Isso inclui o relatório de andamento, medição do progresso e previsão;

* Gerenciar as partes interessadas: gerenciamento das comunicações para satisfazer os requisitos das partes interessadas no projeto e resolver problemas com elas.

A efetivação desses processos de gerenciamento é realizada a partir de um sistema de informação estruturado conforme as necessidades das operações logísticas. Um sistema de informação é um sistema de suporte à decisão capaz de capturar, armazenar, processar e transmitir dados e informações necessárias para a tomada de decisão do empreendimento (ALTER, 1996). A finalidade da utilização desse sistema é produzir melhores resultados que os obtidos sem a estruturação e coordenação das informações para a tomada de decisão do suprimento do empreendimento.

Conforme Rocha Lima (1990) “... identificado o sistema de decisão de uma determinada organização ou empreendimento, estará caracterizado o sistema de informação que esta mesma organização necessita para dar suporte ao seu processo decisório” (ROCHA LIMA, 1990, p.8). Um sistema de informação tem como fundamento servir de suporte para a tomada de decisão do empreendimento, aqui nessa pesquisa, a tomada decisão de suprir o empreendimento com os recursos necessários para a sua implantação.

Cleland e King (1983) questionam como o gerenciamento identifica a quantidade de recursos a serem alocados no projeto e se esses recursos estão sendo utilizados efetivamente em termos dos objetivos e realizações, e indicam como resposta a utilização do sistema de informação. 
Diante das análises acima, é possível admitir que o sistema de informação, quando bem estruturado, produz resultados favoráveis aos processos logísticos devido à capacidade de gerenciar o fluxo de informações relacionadas ao transporte, armazenagem e disponibilização dos insumos do empreendimento.

Um sistema de informação deve ser formatado e planejado para atender as necessidades dos usuários, que é a necessidade de embasamento na tomada de decisão para atender as especificações do planejamento logístico ${ }^{26}$. Desde o início, o objetivo do sistema deve estar bem definido, que no caso dos processos logísticos é auxiliar a solucionar as dificuldades das operações logísticas no ciclo de implantação de empreendimentos. Com a determinação do objetivo é possível identificar o escopo do sistema e o seu ambiente de atuação (CLELAND; KING, 1983).

A elaboração do sistema de informação para as operações logísticas deve encarar o empreendimento de forma sistêmica ao considerar as interfaces com outras áreas do empreendimento como, por exemplo, o gerenciamento de risco e gerenciamento de custo. Essa visão sistêmica beneficia o empreendimento, no que diz respeito a melhorar o entendimento das interligações dos processos, no sentido da decisão de uma área interferir na atividade de outra área.

A identificação do fluxo de informação, estrutura básica do sistema de informação, é fundamental para o gerenciamento de informações. Bowersox (2001) também indica que a necessidade de informações segue o caminho paralelo ao trabalho real executado pela logística. Nesse sentido, o fluxo das informações e dados é identificado pelo fluxo de decisões necessárias para o suprimento do empreendimento.

Outra exigência a ser considerada para o sistema é a flexibilidade. Estudos (ROCHA LIMA, 1990; JAAFARI; MANIVONG, 1998) apontam essa necessidade devido à modificação da demanda de tarefas ao longo do ciclo de vida do empreendimento e as particularidades de cada um. Por isso, é indispensável nessa fase de formatação e planejamento do sistema, identificar as adaptações a serem realizadas pelo sistema ao longo do ciclo de vida do empreendimento.

\footnotetext{
${ }^{26}$ O presente texto não tem a intenção de descrever a metodologia de formatação, planejamento, implantação operação de um sistema de informação. A intenção desse texto é sim de identificar características, requisitos e atividades nas fases de formatação, planejamento, implantação e operação fundamentais para o bom desempenho de um sistema de informação de empreendimentos de construção civil.
} 
Rocha Lima (1990) identifica fatores de qualidade do sistema de informação e esses são indicados a seguir:

Competência técnica - O sistema deve fornecer a informação num nível de entendimento compatível com o nível dos usuários para tomar a decisão, e que, seja possível reconhecer o nível de risco da decisão.

* Capacidade de oferecer simulações do empreendimento - Esse fator está relacionado com a capacidade do sistema de representar o empreendimento, fornecendo informações seguras, quanto ao desenvolvimento do empreendimento em um determinado cenário, como também nas distorções de cenário.

* Capacidade de oferecer informações com velocidade compatível com a exigida para a tomada de decisão - Os sistemas devem fornecer informações em condições viáveis para a tomada de decisão. De nada adianta o sistema entregar informações precisas, se o tempo de fornecimento dessa informação não permite que ajustes sejam realizados para evitar atrasos na entrega das tarefas.

* Capacidade de prover informações de planejamento na medida certa da necessidade dos usuários - A quantidade de informações fornecidas pelo sistema deve ser apenas a quantidade necessária para a tomada de decisão, nem mais, nem menos. Um grande volume de informação ocasiona a fadiga e a falta de informação ocasiona uma tomada de decisão sem embasamento.

Modulação - Esse fator de qualidade corresponde a capacidade de crescer ou diminuir o nível de informação fornecida, a depender da necessidade do usuário.

Adaptabilidade - O sistema deve ser capaz de atender as particularidades de cada empreendimento.

* Facilidade de se ajustar à cultura da empresa - O sistema deve ser ajustável ao nível de conhecimento de seus usuários. Conforme já foi visto anteriormente, com o uso do sistema, o conhecimento do cresce, e o sistema deve ter a capacidade de acompanhar esse nível de conhecimento até o período em que ele se torne obsoleto. 
A identificação das características do sistema de informação que atenda as necessidades das operações logísticas ilustra as diretrizes para o processo do gerenciamento de comunicação. Contudo o PMI (2004) indica que os processos do gerenciamento das comunicações do projeto fornecem as ligações criticas entre pessoas e informações para a comunicação bem sucedida (PMI, 2004, p.221). Ou seja, o sistema de informação coordena as informações do projeto, contudo quem realmente alimenta o sistema com dados e informações é o time de projeto.

Nesse sentido aqui são realizadas algumas análises em relação ao time de projeto. Baiden, Price e Dainty (2005) indicam que o fraco desempenho da construção civil tem sido atribuído ao uso contínuo de práticas do suprimento que não encorajam a integração dos participantes envolvidos. Como também estudos apontam as falhas na organização de projetos de engenharia como a principal causa para o atraso na entrega de insumos (MANAVAZHI; ADHIKARI, 2002; FRIMPONG; OLUWOYE; CRAWFORD, 2003 e JHA; IYER, 2006).

A execução das operações logísticas depende da capacidade da coordenação das informações do projeto realizada pelo time do projeto, e da integração desse mesmo time. Estudos de Elmes e Wilemon (1988) e Baiden, Price e Dainty (2005) indicam características de um time eficiente, em conseqüência, uma time de projeto integrado, e estão indicadas a seguir:

* Os objetivos do projeto são bem definidos e entendidos pelo time - Todos os membros do time devem ter em mente e muito bem esclarecidos os objetivos finais dos processos e atividades realizados por eles.

* As responsabilidades são bem definidas e podem ser alteradas quando houver necessidade - Todos os membros do time devem ter conhecimento das suas responsabilidades a serem executadas, e, quando o projeto requerer modificações, essas devem ocorrer e serem notificadas ao time.

As informações do projeto são compartilhadas livremente entre os membros do time As informações de execução do projeto estão disponíveis para todo o time de projeto, evitando assim, duplicidade de trabalhos devido à falta de informação. 
* Os sucessos e fracassos do projeto são distribuídos igualmente entre o time - O time de projeto é responsável igualmente pelo resultado do seu trabalho. Nesse ambiente, não deve existir a "cultura de culpa” 27.

* Os trabalhos são realizados em benefício, unicamente, do projeto - Todos os processos e atividades são realizados com a finalidade de atingir os objetivos do projeto.

* A composição do time de execução é flexível - O time de projeto deve ser formado por membros com habilidades e competências complementares, e com capacidade de adaptação a modificações do time.

Todos os integrantes possuem oportunidades de contribuir com o projeto - Na delimitação das responsabilidades dos membros do time devem ser considerada, sempre que possível, a delimitação por igual das contribuições ao projeto, para que os integrantes se sintam como uma parte do mesmo.

Os conflitos são gerenciados abertamente e encarados como parte vital para o desenvolvimento do projeto - Em todo desenvolvimento de projeto ocorrem conflitos de idéias, contudo isso deve ser encarado como um enriquecimento do processo devido ao surgimento de novos conhecimentos.

Essas características englobam um conjunto de características necessárias para um time de projeto ser integrado, e por decorrência são validas para o time responsável pelas operações logísticas.

Aqui vale a ressalva que a estrutura da organização que compõe o empreendimento é particular a cada um, devido a as diferentes necessidades dos empreendimentos. Também vale ressaltar que esse texto não tem a pretensão de montar um modelo de estrutura organizacional para o empreendimento hoteleiro, pois é entendido que cada empreendimento possui suas peculiaridades, e em conseqüência, estruturas organizacionais diferentes. Contudo, esse texto pretende identificar diretrizes para uma organização integrada.

\footnotetext{
${ }^{27}$ Entende-se nesse trabalho que cultura de culpa é a cultura de culpar um membro do time ou vários pelas falhas e sucessos ocorridos no projeto.
} 
O gerenciamento das comunicações apenas ocorre de maneira a atender as necessidades das operações logísticas em relação a disponibilização da informação onde, quando e como são necessárias, e para isso, deve existir um sistema de informação que reflita as necessidades das operações logísticas e a integração do time de projeto para a elaboração e transmissão das informações.

\subsubsection{EXECUÇÃO E CONTROLE LOGÍSTICO}

Segundo Cruz, Rodrigues e Novaes (1998) o fluxo logístico em empreendimentos da construção civil envolve a gestão do fluxo material desde o fornecedor, incluindo o transporte, até o local de produção, passando por uma intensa movimentação interna no canteiro de obra até chegar ao ponto de aplicação final.

Esse fluxo inicia-se com negociação de contratação do insumo. A partir dessas informações é possível analisar as condições de transporte e armazenamento dos insumos. Na negociação é analisada a forma de transporte do insumo, a depender das exigências de prazo e custo planejados. A armazenagem também depende da negociação, pois o tempo de armazenagem dependerá se o insumo será entregue antes do prazo de utilização no empreendimento, ou no prazo em que será utilizado no empreendimento. E para os insumos que foram armazenados, em seguida esses devem ser disponibilizados para o empreendimento a depender das condições do canteiro do empreendimento.

Esse fluxo de insumos corresponde a execução dos processos logísticos durante o ciclo de implantação do empreendimento e deve ser controlado conforme as diretrizes apontadas no planejamento logístico. No controle logístico ocorre a verificação e análise de como o empreendimento está sendo executado segundo as especificações do planejamento logístico. Isso é o processo logístico de controle.

Conforme Cleland e King (1983, p.433) o controle de um projeto pode ser definido como:

Previsão e avaliação de potenciais riscos antes de sua ocorrência, para que então ações preventivas possam ser tomadas; 
Rever as tendências ou situações reais para analisar o seu impacto e, se possível, propor ações para aliviar a situação;

Promover constante monitoramento das condições do projeto para efetivamente e economicamente criar uma condição “sem surpresa”.

O controle abrange processos capazes de monitorar os eventos do projeto, como também analisá-los, com o objetivo de manter os padrões de qualidade estabelecidos no planejamento, ou mesmo melhorar esses padrões. Esse processo também tem a função de prever situações de riscos, para então minimizá-los ou eliminá-los, caso esses sejam negativos ao projeto. E caso esses riscos sejam positivos é possível aproveitar a situação para maximizar os resultados estimados para o projeto.

O processo de controle tem como baseline as informações resultantes do planejamento logístico. "Um sistema de controle de projeto tem como alvo minimizar as diferenças entre o planejamento e a execução com a finalidade de atingir os objetivos do projeto, isto é, custo, tempo e conteúdo” (ROZENES; VITNER; SPRAGGET, 2006, p.5). Ou seja, a processo de controle tem como objetivo atingir os resultados especificados na baseline, no caso do processo logístico, atingir o resultado de suprir o empreendimento no prazo e condições requeridas.

Com a análise dos riscos envolvidos no processo logístico do suprimento é possível identificar potencias situações adversas à efetivação do planejamento, como também identificar potenciais situações benéficas aos resultados do projeto. A identificação desses riscos do suprimento permite a sua análise na tomada de decisão do que fazer minimizar, eliminar ou mesmo potencializar, a depender do tipo de risco.

Vale ressaltar o escopo do controle logístico abordado por esse trabalho. É sabido da necessidade de realização de controle das diversas operações do processo (planejamento logístico, gerenciamento das informações e disponibilização dos insumos). Contudo, como as duas últimas operações abordadas são realizadas com a finalidade de efetivar o planejamento, essa seção sobre controle logístico segue a mesma lógica, ou seja, realizar o suprimento segundo o proposto no planejamento. 
Diversos estudos indicam melhoras no resultado dos projetos com o controle eficiente dos processos (ROZENES; VITNER; SPRAGGET, 2006). O processo de controle antecipa eventuais problemas na execução do projeto, como também pode maximizar o resultado final, devido a sua capacidade de análise da condução do mesmo.

A partir dessa análise, é possível conduzir as mudanças que surgem, inevitavelmente, dentro da implantação do projeto. Com relação a essas mudanças, Meredith e Mantel (2000) indicam que como a prevenção de mudanças não é possível, a melhor esperança do projeto é o controle na introdução e no acompanhamento de cada mudança.

Ainda como parte do processo do controle existe previsão e avaliação de potenciais riscos com a finalidade de evitar ou reduzir o impacto de eventos negativos aos resultados do projeto e aumentar o impacto de eventos positivos.

O controle do suprimento é realizado com o propósito de manter e potencializar o resultado do empreendimento com a aproximação do planejamento à efetivação do suprimento, ou seja, a obtenção do padrão de qualidade estabelecido no planejamento. Para isso também é necessário prever ofensores ao andamento do suprimento segundo o seu planejamento, e sempre que necessária, realizar modificações convenientes ao projeto.

Com a definição do controle do suprimento e identificação da sua importância é possível analisar como esse processo é realizado.

Durante a execução do projeto são coletadas informações correlatas, buscando identificar o que realmente ocorreu, ou que está prestes a ocorrer, ou o que irá ocorrer no empreendimento. A análise critica de todas essas informações permite reconhecer se o suprimento está sendo executado de acordo com o planejamento, caso não esteja, as mudanças são realizadas.

Segundo Meredith e Mantel (2000) o mais importante a ser considerado no controle é direcionar as suas atividades e processos para atingir os objetivos do projeto. Essa diretriz pode ser extrapolada para todas as outras operações logísticas, pois todo o processo logístico tem como propósito de auxiliar a atingir os objetivos do projeto.

Diversos autores (PMI, 2004; MEREDITH; MANTEL, 2000; HALPIN; WOODHEAD, 1980) indicam a necessidade da integração dos processos de controle. As informações de 
execução do empreendimento são capturadas e armazenadas pelo o sistema de informação onde a time de projeto as analisa para tomar a decisão de qual caminho seguir. Portanto, é percebido que tanto as informações de execução, com as de planejamento, devem estar disponíveis sempre que houver necessidade, e para isso, é preciso integrar todos os agentes responsáveis pelo suprimento do empreendimento.

A visão sistêmica também deve fazer parte do controle do processo logístico. O controle do tempo é realizado em conjunto com o controle de custos e qualidade dos insumos. Caso esses controles sejam realizados separadamente, as informações resultantes serão incoerentes, pois podem existir situações onde a execução do empreendimento está no prazo, contudo o custo está acima da baseline. Outro exemplo da necessidade do controle sistêmico é quando o prazo e os custos seguem o planejamento, contudo a qualidade dos insumos não é coerente à qualidade especificada.

Com o controle de forma sistêmica, é possível realmente visualizar a situação do empreendimento durante a sua execução, como também prever os resultados antes mesmo do término do empreendimento.

Meredith e Mantel (2000) indicam a necessidade do controle com flexibilidade devido ao repasse de informações e reação frente às mudanças em tempo hábil. “Todos os projetos estão sujeitos a mudanças e o seu sucesso depende de como ele é planejado em primeira instância e como as mudanças são realizadas” (BRITSH STANDARD, 2000, p.24). A efetivação dessas mudanças é influenciada pela flexibilidade do controle diante ás situações adversas que sempre aparecem no empreendimento.

Outra diretriz para o processo de controle logístico é que ele seja realizado de forma simples, a fim de atender as necessidades do empreendimento. As atividades a serem controladas são apenas aquelas que o time de projeto é capaz de controlar com eficiência e eficácia. De nada adianta tentar controlar todas as atividades do empreendimento, se a processo de controle não é capaz de analisar em tempo hábil para a tomada de decisão.

Um item a ser considerado é a complexidade das ferramentas utilizadas com a finalidade de identificar o andamento do empreendimento. Diante dessas ferramentas de análise o time de projeto deve ser capaz de processar as informações, por isso as ferramentas a serem utilizadas devem ser compatíveis com o conhecimento de seus usuários. Como exemplos dessas 
ferramentas existem: gráficos de acompanhamento, planilhas comparativas, análises estatísticas, redes lógicas, barras de Gantt (MEREDITH; MANTEL, 2000).

A formalização de ferramentas e padronização do processo de controle são itens essenciais para o entendimento das informações para a tomada de decisão. Isso dá agilidade à processo diante das adversidades do empreendimento.

Outra forma de proporcionar agilidade, como também maior confiabilidade, à processo de controle, é a sua realização a mais próxima possível de onde a atividade a ser controlada está sendo executada.

De acordo com o relatado várias vezes nessa seção, contudo vale reforçar devido a sua importância, o controle deve ser realizado em tempo hábil. As mudanças no empreendimento serão realizadas no tempo em que seja possível obter os resultados positivos esperados.

Com relação à identificação e análise dos riscos, esse processo deve ser realizado pelos processos de gerenciamento de riscos. Esse gerenciamento envolve o planejamento do gerenciamento, identificação de riscos, analise qualitativa de riscos, analise quantitativa de riscos, planejamento de respostas a riscos, e monitoramento e controle de riscos (PMI, 2004) 28 .

O processo de controle finaliza o ciclo do processo logístico. Essa atividade deve ser realizada ao longo da execução do empreendimento para potencializarem os seus resultados.

“O controle de projeto pode ser visto como um processo de aprendizado cujos membros do projeto trocam informações fazem ajustes e armazenam os resultados” (GOULD, 1977, p. 273). O processo de controle é um processo de aprendizagem para o empreendimento em execução, como também para a execução de futuros empreendimentos.

\footnotetext{
${ }^{28}$ A análise detalhada do gerenciamento de risco não é o foco desse trabalho, contudo caso seja interesse do leitor, maiores detalhes sobre gerenciamento de risco podem encontrados nas dissertações no Núcleo de Real estate da POLI - USP, disponível no site www.realestate.br.
} 


\section{DEFINIÇÃO DA LOGÍSTICA NA IMPLANTAÇÃO DE HOTÉIS}

O presente capítulo tem como objetivo analisar os processos logísticos diante do cenário imposto pelo ciclo de implantação de empreendimentos hoteleiros. Os processos logísticos aqui serão analisados frente às necessidades específicas da implantação e operacionalização de hotéis.

No Capítulo 2 foi analisado o ciclo de implantação dos hotéis, com a finalidade de identificar as características específicas dessa tipologia de empreendimento. No Capítulo 3 foram apresentados os processos gerais da logística e uma análise inicial de sua aplicação em empreendimentos de real estate. Esse corpo de conhecimento embasa a identificação de processos adicionais que atendam as necessidades de suprimento do empreendimento.

Vale aqui uma análise quanto à estrutura hierárquica para o gerenciamento do empreendimento. Segundo Rocha Lima (1994; p.16) o sistema de planejamento possui três subsistemas:

Planejamento estratégico: Envolve a elaboração de metas e parâmetros, que permitiram à empresa procurar e desenhar seus empreendimentos.

* Planejamento tático: Compreende as rotinas de planejamento voltadas para o desenho dos empreendimentos, que deveram contemplar a possibilidade de que esses empreendimentos venham a atingir o desempenho com as políticas traçadas.

Planejamento operacional: identificação do conjunto de diretrizes vinculadas com os procedimentos de gerenciamento das ações no âmbito da produção do produto.

Diante desses níveis de planejamento do empreendimento, aqui nessa pesquisa foram identificadas diretrizes relacionadas ao planejamento, controle e execução do gerenciamento tático do empreendimento. Aqui foram desenhadas proposições de diretrizes táticas do conjunto de processos gerenciais necessários para obtenção do produto formatado.

E esse conjunto de diretrizes foi formatado para o cenário de implantação dos empreendimentos hoteleiros, ou para os demais empreendimentos que apresentarem uma complexidade similar à implantação de hotéis. 
Primeiramente serão identificados os requisitos para os processos logísticos na implantação de hotéis. E em seguida, os processos logísticos são analisados conforme as necessidades adicionais do ciclo de implantação dos hotéis diante dos demais empreendimentos de real estate. Como resultado tem-se os processos logísticos adaptados conforme os requisitos da implantação dessa tipologia de empreendimento.

\subsection{REQUISITOS PARA A LOGÍSTICA NA IMPLANTAÇÃO DE HOTÉIS}

Foram identificadas as seguintes características específicas para o ciclo de implantação de hotéis:

Ao final do ciclo de implantação ocorre a instalação de equipamentos e mobiliário necessários para a operacionalização do hotel, e há a necessidade de integrar esses junto a edificação. Os equipamentos típicos de um hotel não são simplesmente instalados, mas sim integrados à edificação. Essa integração ocorre simultaneamente com as demais atividades da conclusão da edificação.

A etapa final do ciclo de implantação do hotel é caracterizada por uma sobreposição das atividades tradicionais da construção de empreendimentos de real estate com atividades necessárias para a operacionalização do empreendimento. Além da integração dos equipamentos hoteleiros, o próprio processo de partida é desenvolvido em paralelo com a conclusão da edificação. O propósito é que haja o menor intervalo de tempo possível entre o término da obra da edificação e o início da operação do hotel.

* Essa fase do ciclo de implantação é caracterizado pela presença da operadora, como um stakeholder, com intensa influência nas decisões da configuração do empreendimento.

A transferência do empreendimento da equipe de implantação para a equipe de operação, implica em um período no qual o segundo analisa o trabalho do primeiro e verifica se empreendimento foi implantado conforme a baseline. 
Essas características ficam ressaltadas, por exemplo, em aspectos como a implantação dos quartos, pois por menor que seja a estrutura do hotel, um hotel dispõe de um estoque de quartos, que implica na integração simultânea e múltipla de todo um conjunto de insumos. Instalar um quarto é relativamente simples, contudo instalar vários requer coordenação de múltiplos insumos para atender as condições impostas pela baseline.

Também vale ressaltar que o empreendimento pronto para operar, além da estrutura física, inclui sua equipe de operação apta para realizar as atividades características da operação do empreendimento hoteleiro. E para isso essa equipe é inserida no processo ainda no final do ciclo de implantação. Essa equipe assume simultaneamente o trabalho de aceitação do empreendimento, e preparação para atender a operação do empreendimento.

Nessas condições é possível identificar uma situação de conflito: de um lado, os insumos e produtos devem ser instalados pela equipe ligada aos processos de implantação do hotel, por outro lado boa parte desses insumos, antes de ser instalados, devem ser avaliados pela equipe de operação. Uma equipe está sobre pressão para entregar o empreendimento, enquanto outra assume, necessariamente, uma posição crítica e controladora, pois, a partir da aceitação do empreendimento, terá que operá-lo nas condições em que foi aceito. Esse conflito afeta de forma direta a gestão dos processos logísticos.

E esse conjunto de atividades específicas sobrepostas ao cenário típico da implantação de empreendimentos de real estate torna a implantação de hotéis com um alto nível de complexidade e potenciais conflitos. Essas características demandam processos de integração intensa e complexa, com múltiplas interfaces e em um curto espaço de tempo, buscando atender as necessidades de implantar um empreendimento pronto para operar, com todos os componentes necessários.

As características específicas dos hotéis, explicitadas anteriormente, implicam em particularidades nos processos logísticos com relação aos seguintes aspectos:

* A presença dos insumos destinados à operacionalização do hotel, pela sua própria natureza, cria necessidades gerenciais, em particular para a logística, que não são usuais em outros empreendimentos de real estate. Há que identificar as características e processos do ciclo de operação do empreendimento que direcionam a implantação do empreendimento. 
* A necessidade de coordenar e articular as interfaces entre os múltiplos insumos e/ou fornecedores, sejam aqueles típicos de uma construção civil habitacional como aqueles destinados à operacionalização do hotel. Dada a natureza distinta destas duas classes de insumos, os trabalhos de coordenação e articulação se tornam diferenciados, seja em termos de intensidade, como de escopo, interfaces e da manutenção dos requisitos técnicos previamente especificados.

* A concentração do fornecimento, recebimento e instalação dos insumos destinados à operacionalização do hotel em um curto período de tempo, na fase final de seu ciclo de implantação, torna a coordenação dos respectivos prazos de recebimento e instalação um fator crítico para a manutenção da baseline do empreendimento.

A logística trata das condições físicas e de fornecimentos dos insumos (prazos de entrega) característicos a sua operação. Os processos logísticos dos equipamentos e mobiliários exigem reconhecer as características quanto às especificidades dos insumos, prazos de produção e condição de estocagem e transporte. Alguns desses insumos podem possuir prazo de produção similar a construção do empreendimento, como também, existe a possibilidade de demandar por condições de estocagem diferenciadas aos demais insumos.

Diante desse cenário, a logística deve atender aos requisitos identificados a seguir.

Necessidade de integração de insumos não usuais ao cenário da implantação de empreendimentos de real estate aos pacotes de trabalho característicos a qualquer empreendimento de real estate;

Necessidade de coordenação da execução dos pacotes de trabalho característicos à implantação de hotéis em um curto espaço de tempo ao final do ciclo de implantação;

Necessidade de coordenar a execução dos pacotes de trabalhos característicos aos empreendimentos hoteleiros sobrepostos aos pacotes de trabalho presentes na implantação de qualquer empreendimento de real estate;

Coordenação do atendimento às exigências operacionais de vários stakeholders relevantes na configuração final do empreendimento; 
Também ao final do ciclo de implantação, é necessário integrar a equipe de operação às instalações do empreendimento e aos processos de operação do hotel.

A logística, com a sua capacidade de gerenciar o fluxo de insumos, pode auxiliar no gerenciamento desse grande número de aspectos necessários para a preparação do empreendimento pronto para operar. Contudo os processos logísticos devem ser adaptados para atender as necessidades específicas da implantação dessa tipologia de empreendimento.

\subsection{PARTICULARIZAÇÃO DOS PROCESSOS LOGÍSTICOS NA IMPLANTAÇÃO DE HOTÉIS}

A logística deverá ser integrada aos processos gerenciais da implantação de empreendimentos hoteleiros, onde é responsável pelo gerenciamento o fluxo de insumos desde a aquisição até a instalação no empreendimento. "O objetivo da logística é tornar disponível produtos e serviços no local onde são necessários, no momento em que são desejados” (BOWERSOX, 2001, p.19).

Como síntese da seção anterior, os processos logísticos no ciclo de implantação de hotéis devem atender as exigências quanto ao gerenciamento do fornecimento de múltiplos insumos característicos à implantação de hotéis em um curto espaço de tempo ao término da construção da edificação. Além dessa restrição de prazo e especificação técnica diferenciada, esses insumos apresentam múltiplas interfaces e complexidade de integração seja com a edificação ou entre si.

Esses aspectos fazem com que condições gerenciais adicionais devam ser tomadas pela gestão dos processos logísticos, dentro do foco desse trabalho, como:

Processamento de insumos não usuais no ciclo de implantação de empreendimentos de real estate;

Interfaces dos processos de integração múltiplas e complexas;

Interfaces com equipes múltiplas e com focos e interesses distintos; 
* Cronogramas complexos e alto grau de interdependências;

Prazos de processamento das entregas dos fornecimentos versus a alocação dos insumos restritos, freqüentemente sem folga.

Este quadro deixa pouca margem de manobras para situações tais como atrasos na entrega de fornecimentos, falhas no atendimento a requisitos técnicos, incompatibilidade entre insumos e incompatibilidade entre insumos e edificação.

Isso leva a gestão dos processos logísticos de empreendimentos hoteleiros, quando de insumos específicos para a sua operacionalização, a lidar com questões inusitadas não usuais seja no âmbito de empreendimentos de real estate. Há necessidade de processos gerenciais adicionais capazes de:

Controlar o escopo de fornecimento, seja em relação à configuração dos insumos, seja em relação à suas especificações técnicas;

* Controlar de interfaces entre os insumos característicos aos empreendimentos hoteleiros e a edificação, e entre os próprios insumos;

Controlar de interfaces com os fornecedores - identificação das condições de fornecimento.

Diante do exposto são necessários processos gerenciais que auxiliem a atender ao escopo especificado. Silva (2006) utilizou os processos do gerenciamento de configuração com o objetivo de obter o produto planejado ao final do projeto. Esse estudo também aconselha a utilização do gerenciamento de configuração em projetos com grande número de atividades, com alto nível de complexidade. Segundo Samaras (1971) a configuração do produto é uma descrição completa do conjunto de características físicas, suas inter-relações e desempenho do produto. No gerenciamento de hotéis a sua configuração corresponde ao produto final, identificado inicialmente na fase de projeto.

No ambiente da implantação de hotéis, o gerenciamento de configuração envolve processos de coordenação das alterações do produto ao longo do ciclo de vida da implantação do empreendimento, com a finalidade de garantir que o produto final seja compatível com as 
exigências operacionais. Esse gerenciamento também auxilia a atender as exigências da equipe de operação ao final do ciclo de implantação.

A capacidade de analisar e alinhar as interfaces entre o fornecedor e as necessidades do empreendimento ocorre a partir do gerenciamento de interfaces. O conceito básico do gerenciamento de interfaces é que o gerente de projeto planeja e controla o ponto de interação entre vários elementos do projeto, do produto e organizações envolvidas (CLELAND; KING, 1983). O gerenciamento de interfaces no cenário da implantação de hotéis possui a responsabilidade de integrar as necessidades do empreendimento com as condições de fornecimento dos insumos.

Chen, Reichard e Beliveau (2007) analisaram a aplicação do gerenciamento de interfaces na construção de empreendimentos e constaram que utilização do processo em tarefas específicas ajuda a organizar e coordenar recursos, tempo e ambiente para atividades de construção, como também ajuda a reduzir as incertezas e complexidade do projeto.

Com relação à integração dos insumos necessários à operacionalização e à edificação, isso ocorre em função do conjunto de processos do gerenciamento de configuração devido à sua capacidade de configurar o empreendimento de acordo com o produto final e pelo conjunto de processos do gerenciamento de interfaces que tem a função de integrar as interfaces do produto.

Os gerenciamentos de configuração e interface são inseridos aos processos logísticos a partir do gerenciamento de integração e visam atender aos requisitos logísticos da implantação de hotéis para a logística. Esses processos auxiliam à logística ao gerenciar o fluxo de insumos a fim de atender as exigências operacionais do empreendimento impostas no ciclo de implantação.

A Figura 12 mostra como os requisitos da implantação de hotéis direcionam a estrutura de gerenciamento da logística, com a introdução dos processos gerenciais de configuração, interface e integração. 


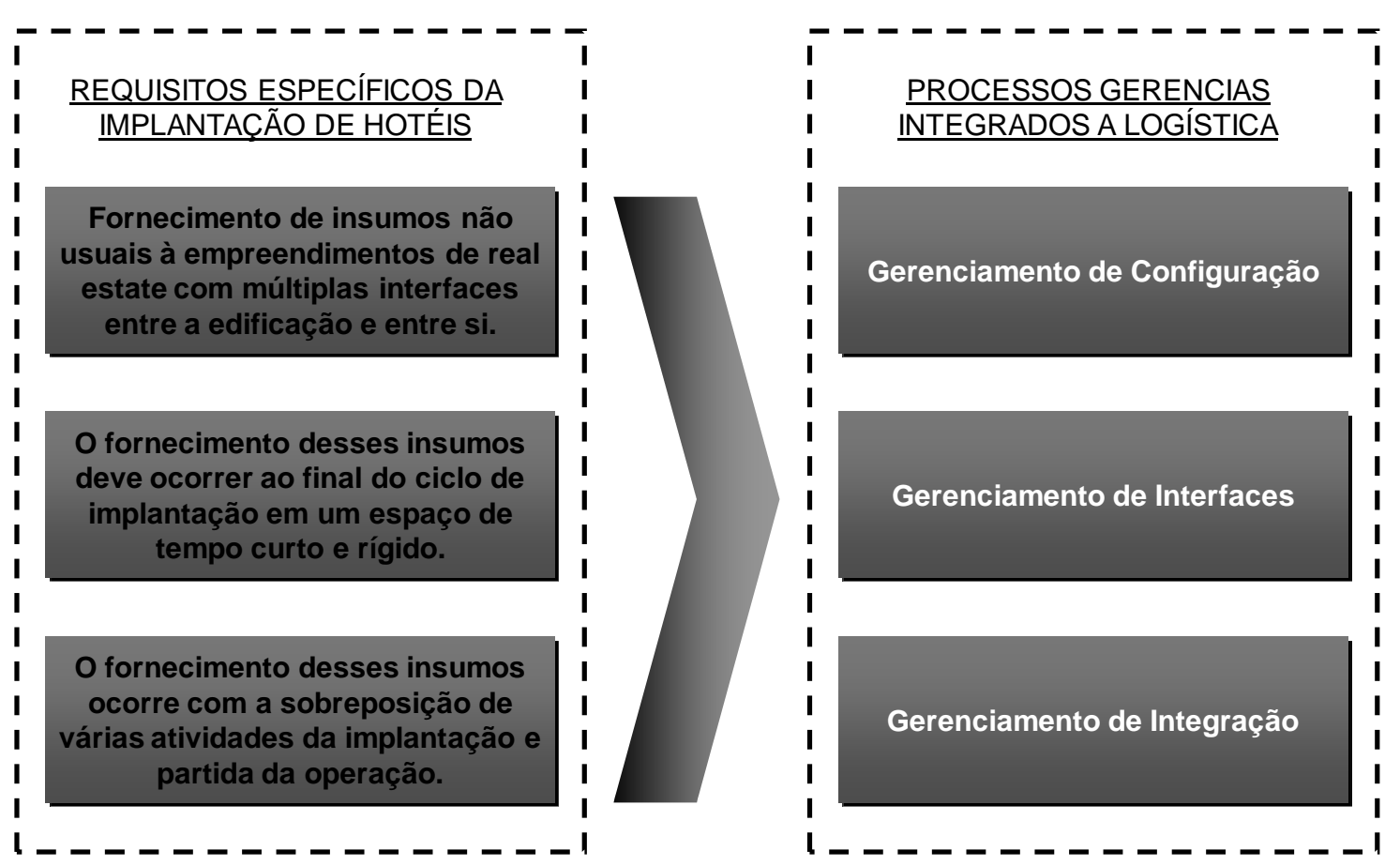

Figura 12 - Requisitos da implantação de hotéis para a logística versus processos gerenciais que integrados a logística atendem as necessidades do empreendimento

Fonte: Desenvolvido pela autora (2008)

A incorporação desses processos gerenciais aos processos típicos da gestão da logística conduz os seguintes propósitos:

Gerenciamento de configuração - consiste na análise dos atributos críticos para a operacionalização do hotel e na associação aos insumos típicos (móveis e equipamentos hoteleiros), a conhecimento de sua manutenção ao longo do ciclo de implantação. Cabe a este conjunto de processos zelar para que eventuais revisões de um dado aspecto de empreendimento seja analisado sistemicamente.

* Gerenciamento de interfaces - conjunto de processos orientados para a manutenção da correta inter-relação entre os pacotes de trabalho, entre pacotes de fornecimento e entre pacotes de trabalho versus fornecimento.

Gerenciamento de integração - é um conjunto de processos destinados a prover condições para a integração simultânea dos aspectos de escopo, prazo, custo e desempenho tanto da edificação como dos pacotes de trabalho característicos a implantação de hotéis. 
A partir dos requisitos impostos pela implantação de hotéis, a gestão da logística incorpora os gerenciamentos de interfaces, de integração e de configuração. O gerenciamento de configuração garante que as especificações dos insumos serão atendidas; o gerenciamento de interfaces coordena as interfaces existentes no empreendimento; o gerenciamento de integração coordena a integração entre esses processos gerenciais e demais processos do gerenciamento do gerenciamento do empreendimento.

No próximo capítulo esses processos adicionais - gerenciamento de configuração, gerenciamento de interfaces e gerenciamento de integração - são analisados com maior detalhe a fim de estruturar os processos da logística no cenário da implantação de hotéis. 


\section{PROCESSOS LOGÍSTICOS NA IMPLANTAÇÃO DE HOTÉIS}

Conforme o exposto nos capítulos anteriores, o processo logístico na implantação de hotéis requer a inclusão de processos gerenciais capazes de atender necessidades específicas dessa tipologia de empreendimento. Com isso o gerenciamento de configuração, o gerenciamento de interfaces e gerenciamento de integração são agregados aos demais processos da gestão da logística.

Nas próximas seções os gerenciamentos de configuração, interfaces e integração são descritos e analisados, e, em seguida, estruturados conforme as necessidades apontadas para os empreendimentos hoteleiros.

\subsection{GERENCIAMENTO DE CONFIGURAÇÃO}

O ciclo de implantação de hotéis possui o objetivo de obter o produto definido no ciclo de formatação, conforme as necessidades dos stakeholders.

O cenário da implantação de hotéis é composto por atividades como projetos, etapas construtivas da edificação, instalação dos equipamentos e mobiliário e partida. Em vários períodos essas atividades ocorrem simultaneamente principalmente ao final do ciclo de implantação, configurando um cenário complexo a ser gerenciado. Nesse cenário, a diversidade e sobreposição de atividades tornam-se pontos críticos a fim de atender as especificações para o produto.

Devido às adversidades impostas pelo cenário da construção da edificação e instalação dos equipamentos durante o ciclo de implantação, mudanças sempre ocorrem na configuração do produto, contudo essas alterações devem estar coerentes com as necessidades e anseios dos stakeholders. Além disso, a mudança em um item pode interferir em outro, e com isso as mudanças devem ser analisadas de forma sistêmica.

Diante das características apresentadas, o gerenciamento configuração é incorporado à gestão da logística na implantação de hotéis com finalidade de coordenar para que as características do empreendimento impostas pelo produto sejam atendidas durante o ciclo de implantação. 
Segundo o PMI (2007) Gerenciamento de Configuração do Projeto (GCP) é um conjunto de processos, atividades, ferramentas e métodos utilizados para gerir determinados itens durante o ciclo de vida do projeto. Estes itens são normalmente denominados Itens Configurados (IC), isto é, itens cuja configuração deve ser controlada durante todo ciclo de implantação. O Gerenciamento de Configuração (GC) tipicamente descreve os mecanismos de gestão do estado físico destes itens durante o seu ciclo de vida (PMI, 2007).

O GC também pode ser definido como o processo de gerenciamento para estabelecer e manter a consistência física do produto e atributos funcionais, com o design e informações operacionais durante seu ciclo de vida (CMII, 1998).

O GC é um conjunto de processos com a finalidade de garantir que o produto entregue ao final do projeto siga as especificações da sua baseline. Essa baseline pode ser aquela definida ao início do projeto, ou a baseline modificada conforme as solicitações ao longo da execução do empreendimento. Contudo essas modificações devem atender às diretrizes inicialmente identificadas para o empreendimento.

Uma das funções do gerenciamento de configuração é a coordenação destas mudanças. As mudanças sempre que necessárias devem ocorrer, contudo devem ser analisadas em função do todo o projeto. A disciplina gerenciamento de configuração também garante que mudanças inter-relacionadas sejam sincronizadas e que sua documentação seja atualizada (FOWLER, 1993, 1996).

O conjunto das atividades do gerenciamento de configuração busca zelar para que o projeto seja entregue com formatação conforme suas necessidades. E para atender essa formatação é necessária a existência de processos de coordenação das mudanças que ocorrem ao longo do projeto.

As responsabilidades típicas do gerenciamento de configuração são (OPFRO, 2005):

Garantir que os stakeholders conheçam os maiores componentes do projeto;

Minimizar as perturbações no projeto devido às mudanças descontroladas nos principais componentes; 
Apresentar informações de auditoria sobre o motivo pelo qual, quando e por quem a baseline foi alterada;

Identificar itens e configuração base para permitir a recuperação das versões específicas de trabalho e de produtos base;

* Controle de mudanças de configuração e itens base para minimizar as perturbações no projeto.

O gerenciamento de configuração introduz a visibilidade do produto final aos processos de gerenciamento ao longo do ciclo de implantação. Como uma das funções da logística é disponibilizar o produto conforme essa configuração, é preciso incorporar as atividades de gerenciamento de configuração do produto aos seus processos, principalmente em relação à disponibilização da configuração atualizada. Como também garantir que as informações disponíveis sejam as mais atualizadas.

Na execução dos processos logísticos a disponibilização de versões atualizadas dos projetos e especificação conforme as necessidades do produto final são as informações iniciais para o processo de fornecimento dos insumos para o projeto. Essas informações devem alimentar o planejamento e re-planejamento dos processos logísticos, e em conseqüência o controle e monitoramento dos processos.

Vale a ressalva de que nem todos os itens do projeto fazem parte do gerenciamento de configuração. Devem ser selecionados os itens de importância relativa para o projeto, aqueles com intensa influência para os resultados do projeto. No presente caso busca-se dotar a gestão da logística da capacidade de minimizar impactos das mudanças de configuração dos itens críticos, com ênfase naqueles destinados à operacionalização do hotel.

No caso dos hotéis, pode-se destacar a necessidade do gerenciamento de configuração no mobiliário e equipamentos dos quartos devido à diversidade e multiplicidade de itens.

As atividades de gerenciamento de configuração do projeto são (PMI, 2007):

Planejamento do gerenciamento de configuração;

Identificação da configuração; 
Gerenciamento das mudanças de configuração;

Registro da configuração;

Verificação e auditoria da configuração.

\section{Planejamento para o gerenciamento de configuração}

O planejamento do gerenciamento de configuração identifica a estrutura das atividades do gerenciamento de configuração de forma a obter a consistência das informações disponibilizadas.

Consiste em descrever a definições gerais do produto e as atividades do gerenciamento de configuração em relação ao planejamento, identificação da configuração, gerenciamento de mudanças, análise do status, verificação e auditoria de configuração e gerenciamento de informação (CMII,1998).

PMI (2007) enfatiza a importância da comunicação para o gerenciamento de configuração. Essa comunicação ocorre a partir das interfaces ${ }^{29}$ tanto de pessoal como de sistemas. A interface pessoal ocorre entre os integrantes do time do projeto, como também, entre os times externos ao projeto e o time do projeto. E a interface de sistemas ocorre entre os sistemas componentes do projeto. Nos hotéis, por exemplo, é critica a interface entre a edificação e o mobiliário.

O planejamento do gerenciamento de configuração fornece as diretrizes para a coordenação da configuração do produto ao logo do projeto. O planejamento indica como devem ocorrer os controles da configuração dos itens e como essas informações estarão disponíveis para os stakeholders.

\footnotetext{
${ }^{29}$ A interface pessoal e interface entre sistemas estão descritas com detalhes na seção sobre gerenciamento de interfaces.
} 


\section{Identificação da configuração do produto}

A identificação da configuração define formas, tamanhos e funções do sistema, relacionadas e referenciadas através de uma árvore estruturada. O processo de identificação da configuração é primeiramente voltado para a definição de quais itens que deverão ser individualmente acompanhados com o gerenciamento de configuração e depois através do gerenciamento de mudanças (FOWLER, 1993).

Segundo CMII (1998) a identificação da configuração do produto descreve:

Estrutura do produto e sua documentação;

Desempenho e outros atributos;

Nível de sinalização da identificação;

Identificação única;

Controle de liberação de documentação;

Distinção entre versões.

Identificação da configuração é uma estrutura organizada descrevendo a composição dos objetos de um projeto (PMI, 2007, p.13). Algumas das informações a serem coordenadas pelo gerenciamento de configuração são informações de mudanças, estrutura organizacional (responsabilidades), registros de riscos, estrutura do contrato, informações de programação, custos, documentação do planejamento, EAP.

A identificação da configuração do produto descreve a baseline, as mudanças do produto ao longo do projeto e as características do produto entregue. Configuração do produto é mapear as características do produto desde a sua formatação até a entrega, segundo uma estrutura definida. E essas características tanto podem ser físicas ou funcionais a depender da necessidade do projeto.

Geralmente, os processos do projeto resultam em estabelecer a baseline aprovada e a descrição relativa no tempo apropriado. A identificação da configuração dos itens enfatiza a 
entrega final do projeto como também eventos significativos, e apresenta a visão do gerente ou cliente ou investidor (PMI, 2007, p.13).

No presente caso, a gestão da logística deverá receber a identificação dos itens de configuração controlada, críticos para a operacionalização do hotel e seus respectivos atributos. Eventuais ajustes nestas configurações devem ser continuamente informados para a gestão da logística, de modo a adequar que a recepção deste tipo de insumo junto aos fornecedores seja:

Observado os requisitos de configuração atualizados;

Identificada eventuais alterações não previstas;

Avaliado o impacto destas eventuais alterações;

Acionados os mecanismos de controle de configuração em tempo hábil para minimizar impactos na eventualidade de mudanças.

Isso significa dotar a logística da capacidade de preservar a baseline, de forma proativa, na recepção de insumos críticos para a operacionalização de um hotel.

\section{Gerenciamento de mudanças}

O gerenciamento de mudanças tem como objetivo à manutenção da baseline e coordenação das mudanças aprovadas.

As atividades do gerenciamento de configuração possuem a função de analisar eventuais mudanças, e, caso sejam necessárias, incorporar-las ao projeto. Além disso, tem a função de armazenar as informações históricas de mudanças no projeto para auditorias e lições aprendidas. As atividades do gerenciamento de mudanças são (PMI, 2007):

Identificação da baseline - identificada na atividade anterior do gerenciamento de configuração, a partir da identificação da configuração do item. 
Solicitação de mudanças - reconhecimento da necessidade da mudança e assim haver uma solicitação formal para essa mudança.

Avaliação da solicitação de mudanças - Avaliação entre os diversos stakeholders das mudanças.

* Avaliação do impacto - Análise sistêmica do impacto da implementação da mudança no projeto.

Revisão da decisão e planejamento - Análise geral da mudança e planejamento da sua efetivação.

Implementação da mudança se aprovada - Efetivação da mudança no projeto.

* Conclusão do processo de mudança - Fechamento do processo de determinada mudança.

Essas atividades devem ocorrer ao longo do projeto a cada mudança ou conjunto de mudanças relacionas. Quando aprovadas essas são incorporadas à baseline do projeto. As atividades têm por objetivo garantir que as mudanças sejam analisadas antes de sua ocorrência e para que as mesmas sejam documentadas, havendo assim, um histórico das ocorrências de mudanças ao longo do projeto.

\section{Análise do Status}

Análise do status corresponde a uma continua e apurada análise da configuração pretendida e a real configuração do projeto em qualquer tempo (FOWLER, 1996). Essa atividade tem a função de feedback ao time do projeto em relação a configuração dos itens e documentação das atividades em relação a configuração inicial e mudanças. A análise de status envolve a consolidação das informações da configuração em um determinado tempo e da baseline em um ou vários repositórios de informações. 


\section{Verificação e auditoria da configuração}

O propósito da verificação e auditoria da configuração é garantir que a composição do projeto sob o gerenciamento de configuração esteja devidamente registrado, acessível, aprovado, rastreado e completamente implantado (PMI, 2007, p.25). Como também tem a função de analisar as possíveis modificações a serem realizadas.

A verificação e auditoria da configuração são realizadas a partir das atividades de planejamento dos eventos, execução dos eventos, elaboração do relatório dos eventos e comunicação dos resultados desses eventos para os stakeholders do projeto (PMI, 2007, p.25).

As atividades do GC estão intimamente interligadas ao gerenciamento de informações. A disponibilização das informações sobre o CG de configuração de cada item depende da eficiência dos processos gerenciamento de informação.

O GC também depende da eficiência do gerenciamento de interfaces já que esse gerenciamento depende das interfaces pessoais no time de projeto, interfaces organizacionais entre os fornecedores e time do projeto e interfaces de sistemas ocorrem na configuração de determinados itens do projeto.

A execução das atividades do gerenciamento de configuração no gerenciamento de projeto ocasiona alterações nos processos usualmente utilizados, como também é necessária a introdução recursos para a realização dessas atividades. Entretanto os ganhos com a introdução dessas atividades já foram evidenciados em várias tipologias de projetos, como projetos de sistema de informação, projetos de navios e mesmo em projetos da construção civil (WATERIDGE, 1999; FOWLER, 1993, 1996). O gerenciamento de configuração auxilia o projeto em relação a atender ao escopo da baseline, em conseqüência auxilia o projeto a atender aos custos e prazos especificados.

Conforme já mencionado, a inclusão do gerenciamento de configuração traz pelo menos duas mudanças significativas na gestão da logística:

(1) Postura proativa: não se trata mais de fazer inspeções de conformidade no recebimento dos insumos, mas sim avaliar adequadamente o impacto de eventuais mudanças ou não atendimento da configuração planejada, e de acionar os mecanismos gerenciais 
adequados antes que os insumos sejam aceitos ou entregues na obra, com condições de desvios.

(2) Capacidade gerencial intrínseca: a gestão da logística passa a ter o discernimento de como tratar de desvios de atributos em sua interface com fornecedores e/ou implantação.

\subsection{GERENCIAMENTO DE INTERFACES}

Segundo Dingle (1997) interfaces são potenciais barreiras para a comunicação e exercício da responsabilidade. Contudo a existência de interfaces é essencial em um projeto, por exemplo, a interface entre organizações ou interfaces entre produtos. Um projeto necessita de informações ou insumos de outras organizações e mesmo esses insumos devem ser integrados a fim obter o produto final projetado.

Como as interfaces são reconhecidas por serem barreiras, e mesmo assim serem essenciais para o projeto essas devem ser definidas e coordenadas a fim de evitar que as mesmas impeçam os resultados esperados para o projeto.

As interfaces em um projeto podem ser das seguintes tipologias (DINGLE, 1997; CLELAND; KING, 1983):

* Interface pessoal - refere-se às interfaces entre as responsabilidades de cada indivíduo do projeto. Essas interfaces quando definidas evitam conflitos e favorecem o bom andamento do projeto.

* Interface organizacional - refere-se às interfaces entre as organizações que trabalham para atender os objetivos do projeto.

Interface de sistemas - refere-se às interfaces entre os sistemas que possuem o objetivo de atender aos padrões de qualidade estabelecidos para o projeto.

Segundo Dingle (1997) essas interfaces tanto podem ser internas como externas ao projeto. As interfaces internas são entre o controle e planejamento do projeto, entre a engenharia e o 
gerenciamento da qualidade do projeto. As interfaces externas podem ser entre gerenciamento de projetos e gerenciamento corporativo; construção e design, investidor e contratados; gerenciamento do suprimento e vendedores, gerenciamento da construção e fornecedores de equipamentos ou materiais; contratantes e subcontratados.

Nesse trabalho, considera-se interface toda transição de responsabilidade seja no fluxo de insumos ou na execução de pacotes de trabalho ou fornecimento.

O gerenciamento de interfaces aumenta o entendimento da produção, como também o entendimento da complexidade da construção. Auxiliando no sentido de identificar a relação entre os insumos componentes do empreendimento, os atributos da interface, quais as operações e métodos de gerenciar as interfaces, quais recursos são necessários e quais as responsabilidades das partes envolvidas (CHEN; REICHARD; BELIVEAU, 2007).

Gerenciamento de interfaces é principalmente a questão de estabelecer rapidamente, uma comunicação confiável e precisa entre várias organizações, grupos, subgrupos e indivíduos que suas atividades têm que ser coordenadas para atingir os objetivos do projeto (DINGLE, 1997). Noteboom (2004) define gerenciamento de interfaces como a reação proativa e mitigação de problemas no projeto, incluindo conflitos de design, aplicação de novas tecnologias, desafios regulatórios, e resolução de conflitos.

Identificar e coordenar as inter-relações presentes na implantação do empreendimento são funções do gerenciamento de interfaces. A identificação das interfaces entre cada organização ou sistema envolve identificar o escopo de cada um e quais insumos são necessários para a execução dos escopos inter-relacionados. Também pressupõe a coordenação da execução de modo que os insumos de interface estejam disponíveis de modo adequado dentro dos requisitos de desempenho previamente definidos.

A interface de dados, criada pelo gerenciamento de interfaces, proporciona a compreensão da interface de informação entre o projeto e sua implantação e também aplica ferramentas avançadas de TI (Tecnologia de Informação) para um efetivo e eficiente gerenciamento de interfaces e controle (CHEN; REICHARD; BELIVEA, 2007).

O gerenciamento de interfaces administra os compromissos físicos e funcionais (ou de desempenho) de itens que se relacionam, assegurando a compatibilidade entre partes que se 
ajustam ou se interferem durante a execução do programa/projeto. No decorrer do ciclo de vida do produto ou sistema, proporcionam comunicação entre as partes envolvidas: requisitos físicos e funcionais e compromissos funcionais entre pessoas, setores do programa e organizações (VALERIANO, 2001).

Na implantação de hotéis é possível reconhecer algumas interfaces críticas como:

Interface organizacional entre os stakeholders;

Interface organizacional entre o time do projeto e fornecedores;

Interface entre o sistema da edificação e sistema dos mobiliários e equipamentos, destinados a operacionalização do empreendimento.

O gerenciamento de interfaces identifica e defini o papel das interfaces presentes no projeto, pois tanto o excesso, como a falta de interfaces pode proporcionar sobreposições ou lacunas no trabalho necessário à consecução do projeto. O gerenciamento de interfaces auxilia o gerenciamento de escopo devido à sua capacidade de identificar o papel de cada interface necessária para o projeto. O gerenciamento de interfaces auxilia a identificação da complexidade do projeto.

O grupo de processos do gerenciamento de interfaces deve antecipar possíveis problemas da fase de implantação do empreendimento, tais como incompatibilidade entre os sistemas construtivos ou divergências entre os interesses dos stakeholders.

As atividades do gerenciamento de interfaces são:

1. Identificação do escopo de responsabilidade de cada organização ou sistema;

2. Identificação das inter-relações de cada organização ou sistema;

3. Monitoramento e controle das interfaces.

A identificação do escopo do projeto e o papel de cada organização e sistema são as informações base para a identificação das interfaces. Esse escopo é identificado pelo gerenciamento de integração de forma preliminar e em seguida pelo gerenciamento de escopo 
de maneira mais detalhada. Com a identificação das interfaces, a atividade de monitoramento e controle auxilia a efetivação das mesmas. Caso exista necessidade de modificar as interfaces identificadas inicialmente, essas são alteradas conforme a necessidade do projeto.

Ao longo da implantação de hotéis existem inúmeras interfaces, contudo é fundamental gerenciar as interfaces críticas do projeto. Aquelas que interferem intensamente nos processos do projeto, como a interface entre os stakeholders, entre o time e os fornecedores e interfaces do produto. A compra dos insumos característicos dos hotéis exige um time especializado, a compra dos equipamentos e mobiliário exige um refinamento no processo de escolha do produto e fornecedor.

A incorporação desse conjunto de processos gerenciais à gestão da logística tem por objetivo dotá-la da capacidade de avaliar eventuais desvios, identificados a partir da gestão de configuração, seja nos pacotes de trabalho e/ou de fornecimento e verificar quais outros poderão ser afetados. Isso permite à gestão da logística atuar nos processos de gestão da comunicação reduzindo os prazos de reação e/ou mitigação face aos desvios observados.

De novo a incorporação deste conjunto de processos gerenciais à gestão da logística vem enfatizar seu papel proativo e de antecipação às condições de risco, da gestão dos suprimentos específicos à operacionalização de hotéis.

\subsection{GERENCIAMENTO DE INTEGRAÇÃO}

“A integração trata principalmente da integração efetiva dos processos entre os grupos de processos de gerenciamento de projetos necessários a realizar os objetivos do projeto dentro dos procedimentos definidos pela organização” (PMI, 2004, p.78). O gerenciamento de integração, no cenário dos processos logísticos para a implantação de hotéis, tem a responsabilidade de integrar os processos logísticos entre si e entre os demais processos do gerenciamento do empreendimento.

Conforme explicitado anteriormente o planejamento logístico depende de informações do projeto, por exemplo, escopo e prazo. O gerenciamento de integração, na implantação de hotéis, integra a logística às demais áreas de gerenciamento, como o gerenciamento de escopo 
e prazo. É papel do gerenciamento de integração integrar os processos logísticos aos processos do gerenciamento de projetos.

Segundo Cleland e King (1983) uma das funções mais importante para o gerente de projetos é integrar os sistemas, para que esses atendam os objetivos do projeto de acordo com o planejamento. Esses mesmos autores (CLELAND; KING, 1983) expõem um conjunto de ações para o gerenciamento da integração, como:

Planejamento para integração;

Desenvolvimento da EAP, programação e orçamento integrados;

Desenvolvimento do controle do projeto integrado;

Gerenciamento de conflitos;

Remover barreiras;

Estabelecer prioridades;

Facilitar a transferência do projeto;

Estabelecer links de comunicação;

\section{Planejamento para integração}

O planejamento para a integração envolve a elaboração de um documento detalhado contendo as diretrizes para o gerenciamento de integração. Esse planejamento deve identificar os problemas de integração, eventos de integração e a inter-relação entre as tarefas e subsistemas. Como também deve identificar as inter-relações entre as atividades e programação da seqüência de eventos.

É função do gerente de projetos identificarem os pontos de integração, já que ele possui uma visão sistêmica do projeto. Todos os participantes do projeto devem ter conhecimento do 
conteúdo desse plano, pois esse documento expõe as diretrizes preliminares para o início do projeto.

Ao longo do projeto, escopo, orçamento e alocação de recursos devem ser analisados periodicamente de maneira a comparar o planejamento com o realizado, analisar se estão sendo executados da maneira eficiente. Freqüentes follow-ups são necessários para garantir a realização do planejamento e caso necessite de revisão.

\section{Desenvolvimento da EAP, programação e orçamentos integrados}

O desenvolvimento da EAP, programação e orçamento é parte do planejamento da integração, e devem estar no documento de planejamento da integração. A programação e orçamento do projeto devem ser elaborados integrados à EAP. Cada pacote de trabalho deve ser associado ao custo, à programação inicial e a programação final. Essa EAP serve como base para o planejamento detalhado do projeto.

\section{Desenvolvimento do controle do projeto integrado}

Qualquer que seja o método utilizado para o planejamento e controle, o mapeamento dos pontos de integração e identificação dos eventos de integração é importante. A rede do projeto deve ser baseada nos eventos de integração para facilitar o gerenciamento.

\section{Gerenciamento de conflitos}


É inevitável a ocorrência de conflitos entre os integrantes do projeto ou organizações. É função do gerente de projetos solucionar os conflitos assim que esses surgirem, ou mesmo, antever os possíveis conflitos.

\section{Remover barreiras}

Barreiras são inevitáveis no projeto e são resultantes dos conflitos. Essas barreiras são geralmente causadas por discordâncias nos métodos de execução do projeto, e sempre que existirem devem ser removidas.

\section{Estabelecer prioridades}

Durante o projeto o gerente necessita estabelecer prioridades diante dos conflitos concernentes às as necessidades da organização que envolvem o projeto ou em relação aos problemas do projeto com relação aos processos ou recursos.

\section{Facilitar a transferência do projeto}

A transferência do projeto envolve a entrega desse para o cliente. Esse processo dever ser planejado cuidadosamente com programação e orçamento para projeto.

\section{Estabelecer links de comunicação}

O gerente de projetos deve estabelecer a estruturação de um subsistema de comunicação.

O gerenciamento de integração envolve um conjunto de ações para a coordenação dos processos de gerenciamento de forma sistêmica, a fim de identificar e executar com eficiência as inter-relações dos processos de gerenciamento do empreendimento. 
Similarmente aos demais processos de gerenciamento inseridos aos processos logísticos, o gerenciamento de integração é incluso devido ao seu caráter proativo. A integração adiciona aos processos logísticos a capacidade de antecipar ou mitigar riscos devido ao conhecimento da execução dos processos do projeto de forma sistêmica, em função do acompanhamento do projeto.

\subsection{SÍNTESE DOS PROCESSOS LOGÍSTICOS NO CICLO DE IMPLANTAÇÃO DE HOTÉIS}

Conforme as análises anteriores, os hotéis possuem características não usuais aos empreendimentos de real estate que demandam processos gerenciais adicionais. Diante dessa necessidade recomenda-se que os processos de gerenciamento de configuração, gerenciamento de interfaces e gerenciamento de integração sejam incluídos no escopo dos processos da gestão da logística.

O gerenciamento de configuração tem a função de garantir que a configuração formatada para o empreendimento, conforme as necessidades dos stakeholders, seja executada ao longo do ciclo de implantação, de acordo com as restrições de prazo intrínseca ao negócio hoteleiro. $\mathrm{O}$ gerenciamento de interfaces também auxilia a atender a configuração do empreendimento devido a sua capacidade de gerenciar as interfaces pessoais e de sistemas que compõem o empreendimento.

Já o gerenciamento de integração zela pela baseline do empreendimento devido à capacidade integração dos processos gerenciais de forma a obter uma visão sistêmica da implantação do empreendimento. Esses processos são estruturados conforme a figura abaixo. 


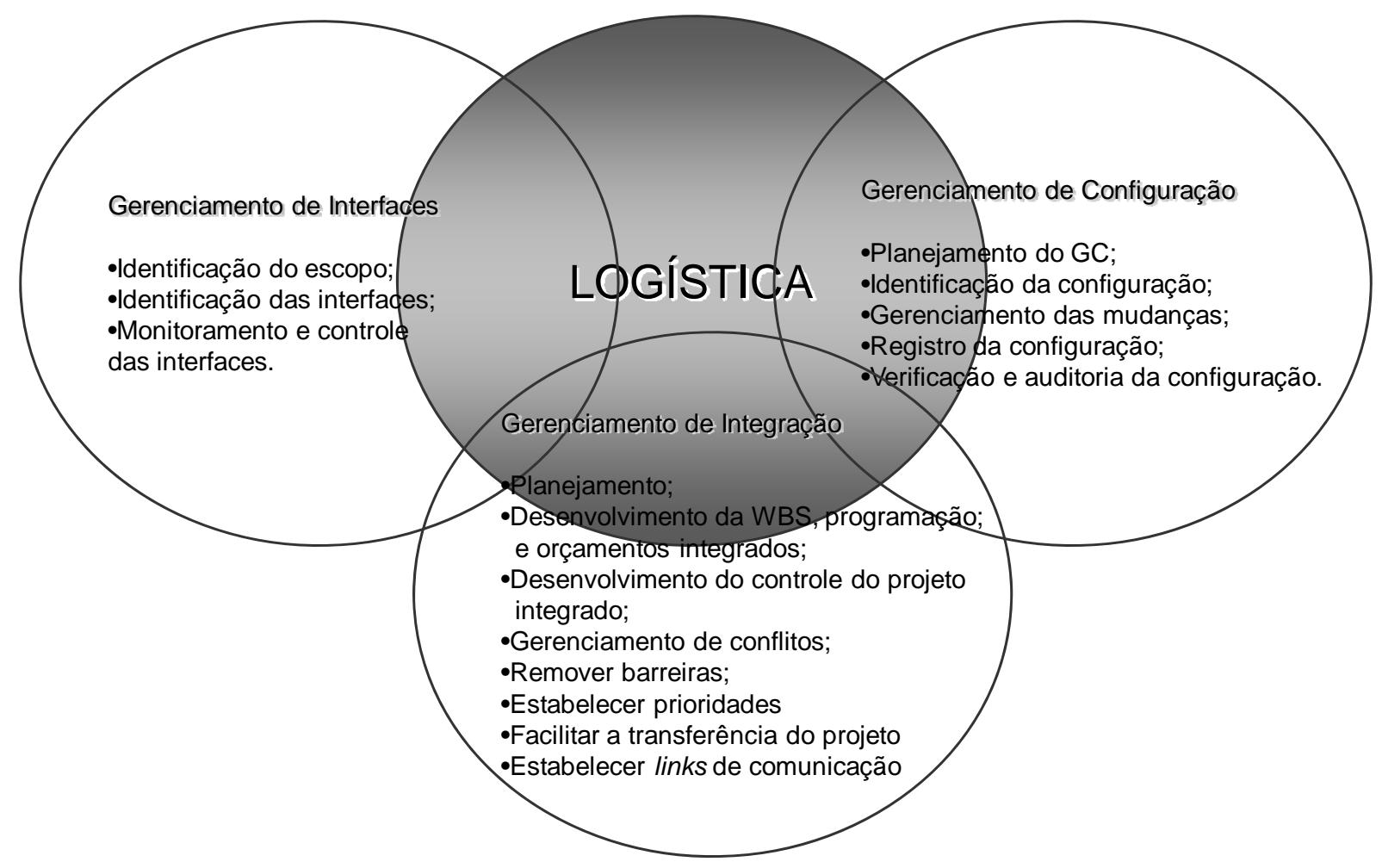

Figura 13 - Estruturação dos processos logísticos na implantação de hotéis Fonte: Desenvolvido pela autora (2008)

Essa estrutura para os processos de gestão da logística no ciclo de implantação de hotéis é composta, além dos processos de planejamento logístico, gerenciamento de comunicação e execução e controle das operações logísticas, por gerenciamento de configuração, gerenciamento de interfaces e gerenciamentos de integração.

Os processos logísticos nessa proposição são integrados a partir do gerenciamento de integração e adicionam competências gerenciais proativas aos processos de gestão da logística com a finalidade de atender aos requisitos do ciclo de implantação de hotéis. Essa nova estruturação dos processos logísticos busca atender as características decorrentes do tratamento de insumos típicos para a operacionalização do empreendimento. Isto é, buscam atender as exigências do escopo diante das restrições de prazo impostas pelo empreendimento.

O conjunto desses processos adicionais busca melhorarem o fornecimento dos insumos a partir do alinhamento das exigências da baseline empreendimento com as características dos insumos e seus fornecedores.

Os processos logísticos recomendados, a fim de atender os requisitos impostos pelas necessidades do ciclo de implantação dos empreendimentos hoteleiros, são: 
Elaboração do planejamento logístico, com relação a insumos versus os requisitos de prazo, custo e qualidade;

Gerenciamento das comunicações relacionadas ao fluxo de insumos;

Execução das operações logísticas - transporte, armazenagem e disponibilização dos insumos nos locais de utilização - e controle;

Gerenciamento de configuração, com a capacidade de identificar desvios no recebimento de insumos e antecipar seus potenciais impactos;

* Gerenciamento de interfaces, com foco na integração dos insumos ao empreendimento, articulação no tratamento de desvios e mitigação do impacto;

* Gerenciamento de integração, orientado à integração dos processos gerenciais.

Para que esses processos atendam aos requisitos de implantação dos hotéis é necessário possuir uma visão sistêmica desse conjunto de processos e dos demais processos do gerenciamento do empreendimento, como também é necessária a integração de todos esses processos relacionados. 


\section{SÍNTESE E RECOMENDAÇÕES}

Esse capítulo tem como objetivo sintetizar as atividades e resultados do trabalho, como também indicar a continuidade da pesquisa para o tema aqui abordado.

Os empreendimentos hoteleiros apresentam sazonalidades nas taxas de ocupação que influenciam expressivamente o resultado do negócio. Diante dessa característica, identificouse que o prazo de implantação está vinculado a um período de oportunidade do mercado para a inserção do empreendimento.

Colocar em operação um hotel, dentro das expectativas de prazo, colabora para que a partida do empreendimento se dê em condições favoráveis quanto à sua inserção no mercado, além de proporcionar melhores condições para sua propaganda, promoção e marketing, ou seja, para sua exposição ao mercado.

Por outro lado, o ciclo de implantação de empreendimentos de real estate é caracterizado pela imobilização de significativa quantidade de recursos financeiros e o quanto antes o hotel for operacionalizado, mais cedo se iniciará seu ciclo de exploração. Isto faz com que o prazo entre a conclusão da construção da edificação e sua colocação em operação seja o menor possível.

Esses aspectos pressionam para que o prazo de implantação do empreendimento seja o menor possível, que a expectativa de prazo seja atendida e que a etapa final da fase de implantação e a fase de operacionalização sejam concomitantes.

Soma-se aos prazos apertados, a necessidade da execução de pacotes de trabalho não usuais no ciclo de implantação de empreendimentos de real estate. Esses pacotes de trabalho são executados simultaneamente aos pacotes de trabalho da construção de qualquer empreendimento, na etapa final do ciclo de implantação, etapa crítica devida à execução de vários pacotes de trabalhos sobrepostos, interdependentes e com interfaces complexas.

Essa complexidade também decorre da multiplicidade de atividades, evidenciada principalmente na instalação dos quartos. Pois instalar um quarto pode ser relativamente 
simples, contudo instalar, de modo coordenado e articulado, uma quantidade significativa de quartos em um curto espaço de tempo ilustra esse cenário complexo a ser gerenciado.

A execução desses pacotes de trabalho não usuais aos empreendimentos de real estate inclui a instalação dos mobiliários e equipamentos necessários à partida para a operação. Esta instalação corresponde à integração desses insumos com uma edificação ainda em fase de conclusão. O que leva a uma primeira sobreposição de atividades.

Por outro lado, a partida corresponde à integração da equipe de operação com o empreendimento. Todos os sistemas, prediais ou operacionais, devem ser testados e colocados em condições de uso o que implica na condução de treinamentos da equipe de operação, tanto nestes sistemas como nas atividades operacionais propriamente ditas. Esta condição leva a um segundo tipo de sobreposição de atividades com as anteriores.

Essas integrações - insumos, equipes de operação e empreendimento - criam a necessidade de coordenar e articular interfaces, com a finalidade de atender à configuração do produto formatado inicialmente.

Essas restrições de prazo, juntamente com a necessidade de execução concomitante de atividades não usuais aos empreendimentos de real estate, demonstram a necessidade de adaptar processos gerenciais ao cenário da implantação de hotéis. Em particular para a gestão da logística dos insumos necessários à operacionalização do hotel, posto ser esta uma atividade crítica para a solução das questões já levantadas e que deve ser desempenhada pela equipe de implantação do empreendimento.

Essas características específicas da implantação de empreendimentos hoteleiros foram identificadas a partir da identificação de uma organização padrão para a estrutura do empreendimento e a partir do estudo de caso sobre uma hipótese de partida para o escopo da implantação de hotéis.

Diante dos processos de gerenciamento da implantação de empreendimentos hoteleiros, os processos do gerenciamento de suprimentos têm como objetivo disponibilizar os insumos requeridos conforme o baseline do empreendimento. Embora referências internacionais da prática do gerenciamento de empreendimentos não enfatizem a gestão da logística dentre os processos de gestão dos suprimentos, o presente trabalho propõe a incorporação e adaptação 
de processos de gerenciamento do fluxo de insumos, papel da gestão logística, para as condições delineadas na fase de conclusão da implantação deste tipo de empreendimentos.

A gestão da logística corresponde ao gerenciamento do fluxo de insumos e informações relacionadas, a fim de auxiliar a atender os requisitos de um projeto. Essa gestão visa garantir a disponibilização dos insumos nas frentes de trabalho, a armazenagem desses insumos quando necessária e o fluxo e seqüência das atividades (SILVA, 2000).

Contudo para a logística atender aos seus objetivos diante as características específicas da implantação de hotéis torna-se necessária a inserção de processos gerenciais adicionais devido a necessidade de integração, em um curto espaço de tempo, dos insumos com o empreendimento e com a sua equipe de operação.

Neste sentido é recomendado neste trabalho que os processos do gerenciamento de configuração, gerenciamento de interfaces e gerenciamento de integração sejam incorporados aos processos usuais da gestão da logística.

A integração desses processos ao escopo da gestão da logística proporciona condições para que esta assuma um posicionamento proativo. A gestão da logística, nesta proposição, deve ser capaz não só de receber os insumos, junto aos diversos fornecedores, mas de analisar se os insumos atendem a configuração do baseline, tanto em relação à especificação como em relação ao prazo.

Como também o conhecimento da configuração do produto, cria condições para que a gestão da logística possa assumir o papel de gerenciadora de conflitos inerentes a esta etapa de recebimento de insumos, de facilitadora do cumprimento dos prazos e de articuladora na gestão de eventuais desvios. O foco no fluxo de insumos atua como mecanismo de redução dos conflitos de aceitação e instalação dos insumos na obra.

Esses processos, por inserirem um caráter proativo à gestão da logística, auxiliam a atingir os prazos de implantação conforme o baseline do empreendimento.

Diante dessa análise é possível constatar que o objetivo da pesquisa de estruturar diretrizes para os processos da logística integrados aos processos do gerenciamento do ciclo de 
implantação de empreendimentos hoteleiros, com foco naqueles aspectos que diferenciam este tipo de empreendimento de outros empreendimentos de natureza imobiliária, foi atendido.

Para finalizar, é proposta a continuidade da pesquisa com relação à aplicação desses processos nos empreendimentos de real estate com complexidade similar aos hotéis, como por exemplo, os hospitais. Como também, recomenda-se a inserção de processos gerenciais, como processos de gerenciamento de prazo e gerenciamento de risco, adaptados para o cenário da implantação de hotéis. 


\section{REFERÊNCIA BIBLIOGRÁFICA}

ABIH - Associação Brasileira da Industria de Hotéis. Apresenta dados sobre o crescimento do setor hoteleiro no Brasil. Disponível em: www.abih.org.br. Acesso em: Março 2006.

ALTER, Steven. Information Systems: A Management Perspective. Menlo Park: Benjamin Cumings, 1996. 728p.

ANDRADE, Nelson. Hotel: planejamento e projeto. São Paulo: SENAC, 2001. 246p.

ANDRADE, Nelson. Debate sobre projeto de interiores e especificação de produtos e equipamentos para hotéis. Revista ProjetoDesign. Edição 271 Set. 2002 Disponível em http://www.arcoweb.com.br/tecnologia/tecnologia27.asp. Acesso em: outubro 2007.

ANTILL, James M.; WOODHEAD, Ronald W.. Critical Path Methods in Construction Practice. New York: Wiley, 1990. 422p.

ASMUSSEN; Michael Willy. Ciclos de Oferta de Hospedagem Comercial Transeunte Impacto na Rentabilidade dos Investimentos em Empreendimentos Hoteleiros. 2004. 92 f. Dissertação (Mestrado) - Escola Politécnica da Universidade de São Paulo. São Paulo, 2004.

BAIDEN, B. K.; PRICE, A. D. F.; DAINTY, A. R. J.. The Extent of Team Integration within Construction Projects. International Journal of Project Management. Disponível em: $<$ http://www.sciendirect.com>

BALLOU, Ronald H.. Logística Empresarial: transporte, administração de materiais e distribuição física. Tradução de Hugo T. Y. Yoshizaki. São Paulo: Atlas, 1993. 388p.

BEHESHTI, Hooshang M. What Mangers Should Know about ERP/ERP II. Management Research News, v. 29, p. 184-193, 2006. n 4.

BOWERSOX, Donald J.. Phisical Distribution Development, Current Status, and Potencial. Journal of Marketing, v. 33, p. 63-70, Jan. 1969. n 1.

BOWERSOX, Donald J. Logística Empresarial. Tradução da Equipe do Centro de Estudos em Logística, Adalberto Ferreira Neves; coordenação da revisão técnica Paulo Roberto Fleury, Cesar Lavelle. São Paulo: Atlas, 2001. 594p. 
BRITSH STANDARD. BS-6979-1:2000: Norma guia para planejamento e execução de projetos e aplicação das técnicas do gerenciamento de projetos. United Kindon: 2000. 52p.

CAMPASSI, Roberta; VALENTTI, Grasiella. Turismo Mira Bolsa para Crescer. Valor Econômico. Valor Econômico, 07 fev. 2008. Empresas \& Tecnologia, B1.

CANTER, TODD A; MAHER, WILLIAM J. An Analysis of Supply and Demand for the U.S. Hotel Industry. Real estate Finance, Vol 15, n 3, pg. 45-56, Fall, 1998.

CARON, F.; FIORE, A.. 'Engineer to order' companies; how to integrate manufaturing and innovative processes. International Journal of Project Management, v. 13, p. 313-319, Jul. 1995. N 5.

CARON, F; MARCHET, G; PEREGO, A.. Project logistics: integrating the procurement and construction processes. International Journal of Project Management, v. 16, p. 311-319, Out. 1998. N 5.

CHEN, Quian; REICHARD, Georg; BELIVEAU, Yvan. Interface Management - A facilitator of Lean Construction and agile Project Management. In: Conference of International Group of Lean Construction., 15. Michigan, USA: July 18 - 20, 2007.

CHRISTOPHER, Martin. Logística e gerenciamento da cadeia de suprimentos: estratégias para redução de custos e melhoria dos serviços. Tradução: Francisco Roque Monteiro Leite. São Paulo: Pioneira. 1997. 240p.

CLELAND, DAVID; KING, WILLIAM. Project Management Handbook. Van Nostrand Reinhold Company: Nova York, 1983. 725p.

CMII - Institute of Configuration Management. ANS/EIA 649-1998. Norma para o gerenciamento de configuração. USA: 1998. 8p. Disponível em: http://www.icmhq.com/. Acessos em abril 2008.

Council of Supply Chain Management Professional. Glossário com a definição de gerenciamento logístico em fevereiro de 2005. Disponível em: http://www.cscmp.org/. Acesso em: setembro 2006.

CRUZ, André L.; RODRIGUES, Carlos T.; NOVAES, Antônio G.. Modelo Logístico para a Construção Civil. In. Encontro Nacional de Tecnologia do Ambiente Construído, 7, 1998, Santa Catarina. Disponível em: www.infohab.org.br. Acesso em outubro 2007. 
DINGLE, J. Project management : orientation for decision makers. London; New York : Arnold: J. Wiley \& Sons, 1997. 279 p.

ELMES, MICHAEL; WILEMON, DAVID. Organizational Culture and Project Leader Effectiveness. Project Management Journal, v. 19, p. 54-63, set. 1988. n 4.

FOHB - Fórum dos Operadores Hoteleiros do Brasil. Apresenta dados sobre o crescimento do setor hoteleiro no Brasil.Disponível em:. Acesso em: www.raioxhotelaria.com.br Maio 2007.

FOWER, A. Model and Aplication of Configuration Management. Int. J. of Mgmt. Sci, v.21, p. 425-431, 1993. N 4.

FOWER, A. Case experience of implementing configuration management in a UK shipbuilding organization. International Journal of Project Management, v. 14, p. 221230, 1996. N 4.

FRIMPONG, YAM; OLUWOYE, JACOB; CRAWFORD, LYNN. Causes of Delay and Cost Overruns in Construction of Groundwater Projects in Developing Countries: Ghana as a Case Study. International Journal of Project Management, v. 21, p. 321-326, Jul. 2003. N 5.

GALLAGHER, MARK; MANSOUR ASIEH. An Analysis of Hotel Real estate Market Dynamics. The Journal of Real estate Research, Vol 19, pg. 133-162, jan - abr, 2000.

GONÇALVES, Gisela B. Debate sobre projeto de interiores e especificação de produtos e equipamentos para hotéis. Revista ProjetoDesign. Edição 271 Set. 2002 Disponível em http://www.arcoweb.com.br/tecnologia/tecnologia27.asp. Acesso em: outubro 2007.

GOULD, Frederick E. Managing the construction process : estimating, scheduling, and project control. Upper Saddle, N.J.: Prentice Hall, 1997. 338p.

HAGA; Heitor Cesar Riogi. Gestão da rede de suprimentos na construção civil: integração a um sistema de administração da produção. 2000. 135 f. Dissertação (Mestrado) - Escola de Engenharia da São Carlos, Universidade de São Paulo. São Paulo, 2000 .

HALPIN, DANIEL W; WOODHEAD, RONALD W. Construction Management. New York : Wiley, 1980. 483p. 
ISATTO; Eduardo Luis. As relações entre empresas construtoras de edificações e seus fornecedores de materiais. 1996. 168 f. Dissertação (Mestrado) - Escola de Engenharia, Universidade Federal do Rio Grande do Sul, 1996.

JAAFARI, ALI; MANIVONG, KITSANA. Towards a Smart Project Management Information System. International Journal of Project Management, v. 16, p. 249-265, Ago. 1998. $n$.

JHA, K. N; IYER, K. C. Critical Determinants of Project Coordination. International Journal of Project Management, v. 24, p. 314-322, maio. 2006. N 4.

KAUFFMAN Jr., DRAPER L. Systems One: A Introdution to Systems Thinking. Ed. S.A. Calton, Publisher Minneapolis. 1980.

KENT Jr., JOHN L; FLINT, DANIEL J. Perspective on the Evolution of Logistic Thought. Journal of Business Logistics, v. 18, p. 15-29, 1997. n 2.

LAMBERT, DOUGLAS M; STOCK, JAMES R. Strategic Logistic Management. Chicago: Irwin, 1993. 862p.

LAMBERT, DOUGLAS M; STOCK, JAMES R; ELLRAM, LISA M. Fundamentals of Logistics Management. Boston : Irwin/McGraw-Hill, 1998. 611p.

LEITE, PAULO ROBERTO. Logística Reversa: Meio Ambiente e Competitividade. São Paulo: Prentice Hall, 2003. 250p.

MANAVAZHI, MOHAN R.; ADHIKARI, DNESH K.. Material and Equipment Procurement Delays in Highway Projects in Nepal. International Journal of Project Management, v. 20, p. 627-632, nov. 2002. N 8.

MASTERS, JAMES M; POHLEN, TERRANCE L. The logistics handbook / [Ed] James F Roberson, Willian C Copacino. New York : Free, 1994. 954p.

MATTOS; Andrea Cilene de. Diretrizes para o Dimensionamento do Número de Unidades Habitacionais de Hotéis Resort. 2004. 108 f. Dissertação (Mestrado) - Escola Politécnica da Universidade de São Paulo. São Paulo, 2004.

MEREDITH, JACK R; MANTEL, JR, SAMUEL J. Project Management : A Managerial Approach. New York : Wiley, 2000. 616p. 
MUNK, FRANTISEK. The Problem of Distribution Cost. Journal of Marketing, v. 1, p. 6667, Jul. 1936. n 1.

NOTEBOOM, Uri. Interface Management improves on-time, on-budget delivery of magaprojectos. JPT Management, 32-34, Ago, 2004.

OPFRO - Open Process Framework Repository Organization . Informações sobre a estruturação dos processos do gerenciamento do Configuração. Disponível em http://www.opfro.org/index.html?Components/WorkUnits/Activities/ConfigurationManagem ent/ProjectConfigurationManagement.html Contents. Acesso em abril 2008.

ORLICKY, JOSEPH. Material Requirements Planning: The New Way of Life in Production and Inventory Management. New York : McGraw-Hill, 1975. 292p. WHEATON, W.C. Real estate Cycles: Some Fundamentals. Real estate Economics, Vol 27, pg. 209-230, 1999.

PMI - PROJECT MANAGEMENT INSTITUTE. A Guide to the Project Management Body of Knowledge. $3^{\circ}$ ed. Pennsylvania: Project Management Institute, Inc, 2004. 403p.

PMI - PROJECT MANAGEMENT INSTITUTE. Practice Standard for Project

Configuration Management. Pennsylvania: Project Management Institute, Inc, 2007. 53p.

FOHB - Fórum dos Operadores Hoteleiros do Brasil. Divulgação de resultados da pesquisa Raio X da Hotelaria sobre os dados do setor hoteleiro no Brasil. Disponível em: http://www.raioxhotelaria.com.br/. Acesso em setembro 2007.

ROCHA LIMA Jr, JOÃO DA. Sistema de Informação para o Planejamento na Construção Civil - Gênese e Informatização. Escola Politécnica da USP. 1990

Fundos de Investimento Imobiliário e Títulos de Investimento de Base

Imobiliária. Escola Politécnica da USP. 1994.

Gerenciamento na Construção Civil - Uma Abordagem Sistêmica.

Escola Politécnica da USP. 1998.

ROZENES, SHAI; VITNER, GAD; SPRAGGET, STUART. Project Control: Literature Review. Project Management Journal, v. 37, p. 5-14, set. 2006, n 4. 
SAMARAS, Thomas T. Fundamentals of configuration management. New York : WileyInterscience, 1971. 371p.

SILVA, FRED BORGES DA. Conceitos e Diretrizes para a Gestão da Logística no Processo de Produção de Edifícios. 2000. 206 p. Dissertação (Mestrado em Engenharia de Construção Civil) - Escola Politécnica da Universidade de São Paulo. São Paulo. 2000.

SILVA, SÉRGIO ALFREDO ROSA DA. Programações por Recursos: O Desenvolvimento de um Método de Nivelamento e Alocação com Números Nebulosos para o Setor da Construção Civil. 1999. 276 p. Teses (Doutorado em Engenharia de Construção Civil) - Escola Politécnica da Universidade de São Paulo. São Paulo. 1999.

WHEATON, W.C.. Real Estate “cycles”: Some Fundamentals. Real estate Economics, Vol 27, pg. 209-230, 1999.

WHEATON, W.C.; ROSSOFF, L. The cycle Behavior of the U.S. Loading Industry. Real estate Economics, Vol 26, pg. 430-436, 1998.

WATERIDGE, JOHN. The Role of Configuration Management in Development and Management of Information System/Technology (IS/IT) Projects. International Journal of Project Management, v. 17, p. 237-241, Ago. 1999. n 4.

VILLAGÁRCIA ZEGARRA, SOFIA LILIANE. Diretrizes para Elaboração de um Modelo de Gestão de Fluxo de Informações como Suporte de Logística em Empresas Construtoras de Edifícios. 2000. 214 p. Dissertação (Mestrado em Engenharia de Construção Civil) - Escola Politécnica da Universidade de São Paulo. São Paulo. 2004.

VALERIANO, Dalton L.. Gerência em projetos : pesquisa, desenvolvimento e engenharia. São Paulo: Makron Books, 1998. 438p.

YEO, K.T.; NING, J. H.. Integrating supply chain and critical chain concepts in engineerprocure-construct (EPC) projects. International Journal of Project Management, v. 20, p. 253-262. 2002.

YIN, Robert K.. Estudo de caso: planejamento e método. Tradução de Daniel Grassi. Porto Alegre: Bookman, 2005. 212p. 


\section{BIBLIOGRAFIA CONSULTADA}

ASMUSSEN; MICHAEL WILLY. Entendendo o Jargão Hoteleiro: Conceitos e Terminologia Basicos do Ramo Hoteleiro. Real estate: Economia e Mercados, São Paulo, v. 2, p. 1-42, jan-jun. 2005. N 1.

IBBS, C. WILLIAM; WONG, CLARENCE K.; KWAK; YONG HOON. Project Change Management System. Journal of Management in Engineering, v. 17, p. 159-165, jul. 2001. n 3.

RUPPENTHAL, KARL MAXWELL. Business logistics in American industry. Stanford, Calif.: Graduate School of Business, Stanford University, 1968. 403p.

RUTES, WALTER A. Hotel planning and design. New York : Whitney Library of Design, 1985. 256p.

STUKHART, GEORGE. Construction Materials Management. Marcel Dekker inc.: New York, 1995. 328p. Localização: 691st95c (produção)

The logistics handbook / [Ed] James F Roberson, Willian C Copacino. New York : Free, 1994. 954p. 
APÊNDICE 01

INFRA-ESTRUTURA DOS EMPREENDIMENTOS HOTELEIROS 


\begin{tabular}{|c|c|c|c|c|c|c|c|c|c|c|c|}
\hline HOTEL: & 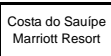 & 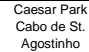 & $\begin{array}{c}\text { Hit ina de } \\
\text { comancaluba }\end{array}$ & 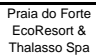 & 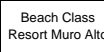 & 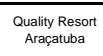 & 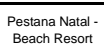 & 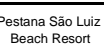 & 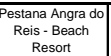 & 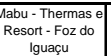 & 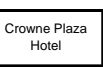 \\
\hline RADOPA: & Marriot & Caesar Park & $\begin{array}{l}\text { Thateds } \\
\text { Transastica } \\
\end{array}$ & 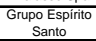 & Altânicica & Allananica & Grupo Pestana & 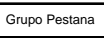 & $\begin{array}{ll}\text { Grupo Pestana } \\
\end{array}$ & & \\
\hline 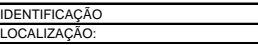 & $\frac{1}{\text { Bania }}$ & $\frac{2}{\text { enambuco }}$ & $\begin{array}{l}3 \\
\text { Batia } \\
\end{array}$ & $\begin{array}{ll}\text { Bahia } \\
\text { Bats }\end{array}$ & $\frac{5}{\text { Pemantuc }}$ & 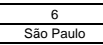 & 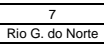 & $\frac{8}{\frac{8}{\text { Marahicic }}}$ & $\frac{9}{\text { Rio de Janeit }}$ & $\begin{array}{ll}10 \\
\text { Parana } \\
\end{array}$ & $\frac{11}{\text { Belem }}$ \\
\hline \multicolumn{12}{|l|}{ 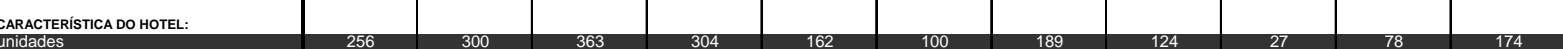 } \\
\hline $\begin{array}{l}\text { andares } \\
\text { suites }\end{array}$ & 4 & $\sqrt{\overline{175}}$ & 5 & 1 & $\square$ & $\square$ & $\square$ & $\square$ & $\square$ & $\square$ & 17 \\
\hline $\begin{array}{l}\text { Stures } \\
\text { bangaloss (chales) }\end{array}$ & 包 & 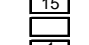 & $\frac{133}{1111}$ & 1 & $\begin{array}{ll}\frac{128}{34} \\
34\end{array}$ & ए & 㟒 & ए & 27 & 包 & 1 \\
\hline $\begin{array}{l}\text { andara apartamento preferencicial } \\
\text { Apartamentos sara deficientes }\end{array}$ & $\square$ & $\frac{1}{14}$ & 239 & $\square$ & $\square$ & 1 & $\square$ & $\square$ & $\square$ & $\square$ & $\square$ \\
\hline 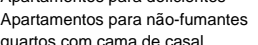 & 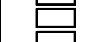 & "一 & 焉 & $\square$ & 10 & 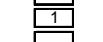 & ב" & 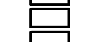 & 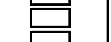 & 㟒 & $\frac{129}{1129}$ \\
\hline $\begin{array}{l}\text { quararos com cama de casal } \\
\text { quartos com cama de solteiro }\end{array}$ & $\square$ & $\square$ & 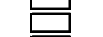 & $\square$ & 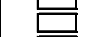 & 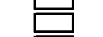 & 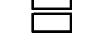 & 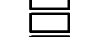 & $\rightleftarrows$ & 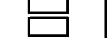 & $\frac{188}{996}$ \\
\hline $\begin{array}{l}\text { downtown/city center } \\
\text { balacão oda aênnia de viagem }\end{array}$ & $\square$ & $\square$ & $\square$ & 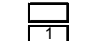 & $\square$ & 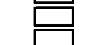 & 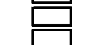 & $\square$ & $\square$ & 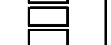 & 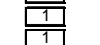 \\
\hline balcăo da locadora de aviaçăo & $\square$ & 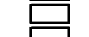 & $\square$ & $\square$ & $\square$ & $\square$ & 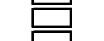 & $\square$ & $\square$ & 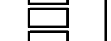 & 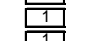 \\
\hline balcão de informaçēes turisiticas & $\square$ & 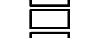 & 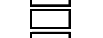 & 1 & & $\square$ & & & & $\square$ & 10 \\
\hline 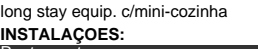 & $\square$ & $\square$ & $\square$ & & $\square$ & $\square$ & $\square$ & $\square$ & $\square$ & $\square$ & $\square$ \\
\hline \multicolumn{12}{|l|}{$\begin{array}{l}\text { Resauaranines } \\
\text { saláa de coquelel } \\
\text { Bares }\end{array}$} \\
\hline Lobby bar & $\square$ & $\square$ & $\square$ & $\square$ & 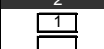 & 19 & $\square$ & $\square$ & $\square$ & $\square$ & $\square$ \\
\hline $\begin{array}{l}\text { Recreativa/esporte } \\
\text { Retis }\end{array}$ & $\square$ & $\square$ & $\square$ & $\square$ & $\square$ & 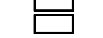 & 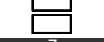 & $\square$ & 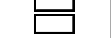 & 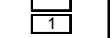 & 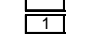 \\
\hline \\
\hline $\begin{array}{l}\text { Recreativo para crianngas } \\
\text { Boate }\end{array}$ & 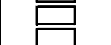 & 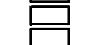 & 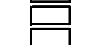 & 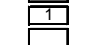 & 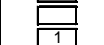 & 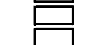 & 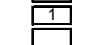 & $\bar{~}$ & $\bar{E}$ & 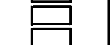 & 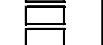 \\
\hline $\begin{array}{l}\text { Brinquedoteca } \\
\text { aluauel de bicileta }\end{array}$ & 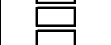 & 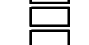 & 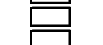 & $\begin{array}{ll}1 \\
\end{array}$ & 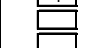 & 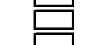 & "ב & $\square$ & 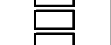 & 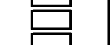 & 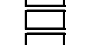 \\
\hline \multirow{2}{*}{\multicolumn{12}{|c|}{$\begin{array}{l}\text { Piscinana de biriball } \\
\text { Piscinana intantil }\end{array}$}} \\
\hline & $\square$ & $\square$ & $\square$ & $\square$ & $\square$ & $\frac{1}{11}$ & $\square$ & ए & $=$ & 焉 & $\square$ \\
\hline Parque aquático & $\square$ & 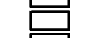 & 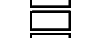 & 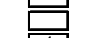 & $\square$ & 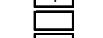 & $\begin{array}{ll}1 \\
\end{array}$ & 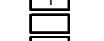 & 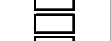 & 㟒 & 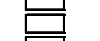 \\
\hline $\begin{array}{l}\text { Shaby copad } \\
\text { Hidromassagem }\end{array}$ & 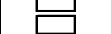 & म् & 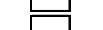 & 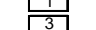 & 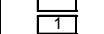 & + & 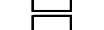 & $\square$ & 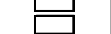 & 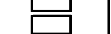 & \\
\hline playground & $\square$ & $\square$ & $\square$ & $\square$ & 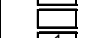 & 0 & 0 & $\square$ & 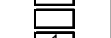 & $\square$ & 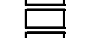 \\
\hline $\begin{array}{l}\text { Heliponto } \\
\text { vista paronâmicaca }\end{array}$ & 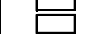 & 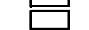 & 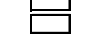 & $=$ & 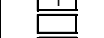 & 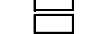 & 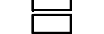 & 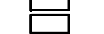 & 5 & 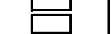 & 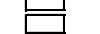 \\
\hline foyer & $\square$ & $\square$ & $\square$ & $\square$ & $\square$ & $\square$ & 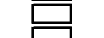 & $\square$ & $\square$ & $\square$ & $\square$ \\
\hline sala de artes & 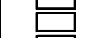 & 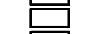 & 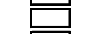 & 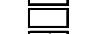 & $\square$ & 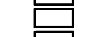 & & $\square$ & $\square$ & $\square$ & $\square$ \\
\hline $\begin{array}{l}\text { Servico de daby sitter } \\
\text { Servicos de médico }\end{array}$ & $\square$ & $\square$ & $\square$ & 1 & $\square$ & $\square$ & 1 & 1 & 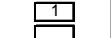 & $\square$ & $\square$ \\
\hline & $\square$ & $\square$ & $\square$ & $\square$ & $\square$ & 1 & $\square$ & $\square$ & $\square$ & $\square$ & $\square$ \\
\hline \multicolumn{3}{|l|}{ 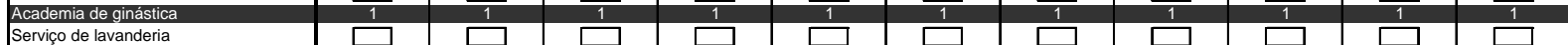 } & $\square$ & $\square$ & $\square$ & $\square$ & $\square$ & $\square$ & $\square$ & $\square$ & $\square$ \\
\hline $\begin{array}{l}\text { Biblitocaca } \\
\text { Home theater }\end{array}$ & $\square$ & $\square$ & $\square$ & 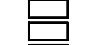 & $\square$ & $\frac{10}{10}$ & $\square$ & $\square$ & $\square$ & $\square$ & $\square$ \\
\hline $\begin{array}{l}\text { Lojad de conveniênciia } \\
\text { Pista de dança }\end{array}$ & $\square$ & 라 & $\frac{.}{\angle 1}$ & $\square$ & $\begin{array}{ll}1 \\
\end{array}$ & 1 & & $\square$ & $\square$ & 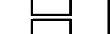 & $\square$ \\
\hline 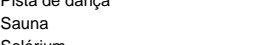 & 1 & 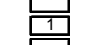 & $\frac{1}{11}$ & 1 & 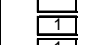 & 1 & 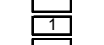 & 1 & 1 & 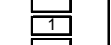 & 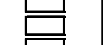 \\
\hline $\begin{array}{l}\text { Solalum } \\
\text { Salán de belezza }\end{array}$ & $\square$ & $\overline{10}$ & 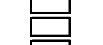 & 1 & 17 & 1 & 4 & $\square$ & 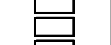 & $\square$ & $\square$ \\
\hline $\begin{array}{l}\text { Butiques } \\
\text { andares executivo }\end{array}$ & 至 & 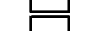 & 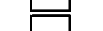 & $\square$ & 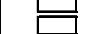 & 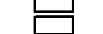 & 1 & 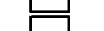 & $\neg$ & $\square$ & $\Rightarrow$ \\
\hline suties executiva & $\square$ & $\bar{G}$ & $\square$ & $=$ & $\square$ & $\square$ & 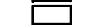 & = & $=$ & $\bar{\square}$ & $\square$ \\
\hline $\begin{array}{l}\text { banca de jornal } \\
\text { Sanal }\end{array}$ & (2) & 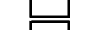 & 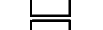 & 1. & $\square$ & 品 & $\square$ & $\square$ & 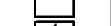 & 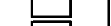 & $\square$ \\
\hline cher caté & 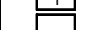 & 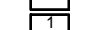 & 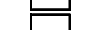 & 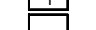 & 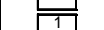 & 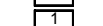 & "L & 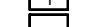 & 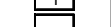 & $\Rightarrow$ & \\
\hline Churrasqueira & $\square$ & 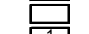 & $\square$ & $\square$ & $\square$ & $\square$ & 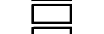 & $\square$ & $\square$ & 10 & 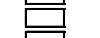 \\
\hline & $\square$ & 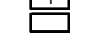 & & $\square$ & 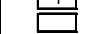 & $\square$ & 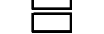 & -5 & $\partial$ & $\square$ & $\square$ \\
\hline Concierge & $\square$ & $\square$ & $\square$ & 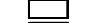 & $\square$ & $\square$ & 1 & 1 & & {[} & \\
\hline $\begin{array}{l}\text { Futubololosociety } \\
\text { Futebol }\end{array}$ & 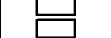 & 1 & 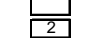 & $\underline{11}$ & 1 & 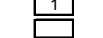 & 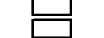 & $\frac{\square}{11}$ & 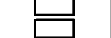 & \begin{tabular}{|l|l|}
1 \\
1
\end{tabular} & 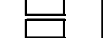 \\
\hline $\begin{array}{l}\text { Anfteatro } \\
\text { Xatro }\end{array}$ & $\square$ & $\square$ & $\square$ & 1 & $\square$ & $\square$ & $\square$ & 马 & & & 马 \\
\hline 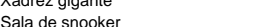 & $=$ & 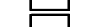 & 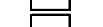 & 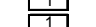 & 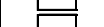 & 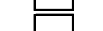 & 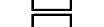 & 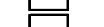 & 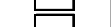 & 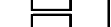 & 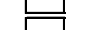 \\
\hline Quadra de copper & 10 & 1 & 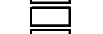 & 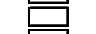 & $\square$ & $\square$ & 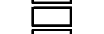 & $\square$ & $\square$ & $\square$ & $\square$ \\
\hline $\begin{array}{l}\text { spinininge pelates } \\
\text { Quadra de tenis }\end{array}$ & 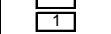 & 4 & 5 & 4 & 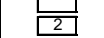 & 4 & 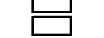 & 1 & $\square$ & 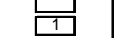 & 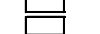 \\
\hline Quadra de volei de praia & $\square$ & & & 1 & & & & & $=$ & & 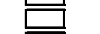 \\
\hline 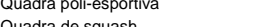 & 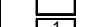 & 24 & " & & 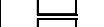 & 1 & 1 & 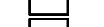 & $=$ & $\square$ & $\Rightarrow$ \\
\hline $\begin{array}{lll}E c & \end{array}$ & 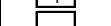 & 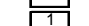 & 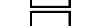 & 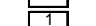 & 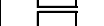 & 1 & (2) & 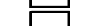 & $=$ & $=$ & 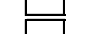 \\
\hline & 1 & $\square$ & 1 & $\square$ & $\square$ & $\square$ & 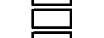 & $\square$ & $\square$ & $\square$ & $\square$ \\
\hline $\begin{array}{l}\text { Raftug } \\
\text { Nautica (windsurf, caiaques...) }\end{array}$ & $\frac{1}{11}$ & $\square$ & 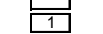 & 1 & 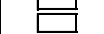 & 4 & 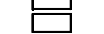 & $\square$ & 1 & $\square$ & 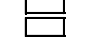 \\
\hline Pesca esportiva & $\square$ & $\square$ & 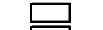 & $\bar{\square}$ & $\square$ & 1 & 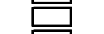 & 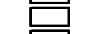 & $=$ & 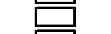 & 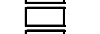 \\
\hline $\begin{array}{l}\text { A Alugue le } \\
\text { Kayaing }\end{array}$ & 4 & ב् & 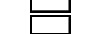 & $\square$ & ب & 1 & 际 & $\square$ & 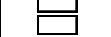 & $\square$ & $\square$ \\
\hline 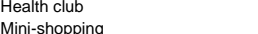 & 1 & $\square$ & $\square$ & $\square$ & $\square$ & $\square$ & $\square$ & $\square$ & 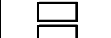 & $\square$ & $\square$ \\
\hline Jacuzzi co & 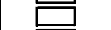 & $\mathrm{E}$ & $\square$ & 1 & 2 & 1 & 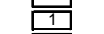 & 1 & $\square$ & $\square$ & 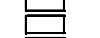 \\
\hline $\begin{array}{l}\text { Jacuzzi parti } \\
\text { Sala de ening }\end{array}$ & 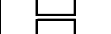 & ب & $\square$ & $\frac{1}{\nu_{1}}$ & 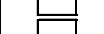 & 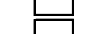 & ب & L & 1 & $\square$ & $\square$ \\
\hline $\begin{array}{l}\text { Sala de jogo: } \\
\text { Salus }\end{array}$ & & $\square$ & & $\frac{11}{11}$ & 11 & 11 & 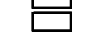 & 1 & 1 & 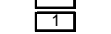 & 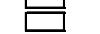 \\
\hline $\begin{array}{l}\text { fitness ce } \\
\text { Massager }\end{array}$ & $\square$ & $\overline{11}$ & $\square$ & 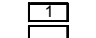 & 1 & $\square$ & $\overline{\bar{\square}}$ & $\square$ & $\square$ & $\square$ & $\square$ \\
\hline $\begin{array}{l}\text { Wuassagem } \\
\text { Business center }\end{array}$ & 10 & 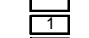 & 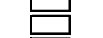 & 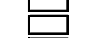 & 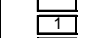 & 1 & $\begin{array}{ll}11 \\
1\end{array}$ & $\perp$ & 1 & $\square$ & 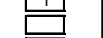 \\
\hline 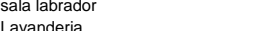 & $=$ & $=$ & 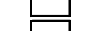 & $=$ & & 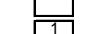 & $=17>$ & 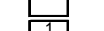 & $\bar{\nabla}$ & ب & $\square$ \\
\hline 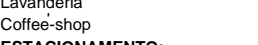 & $\square$ & $\square$ & $\square$ & $\square$ & 1 & 1 & 1 & 1 & 1 & $\square$ & $\square$ \\
\hline
\end{tabular}




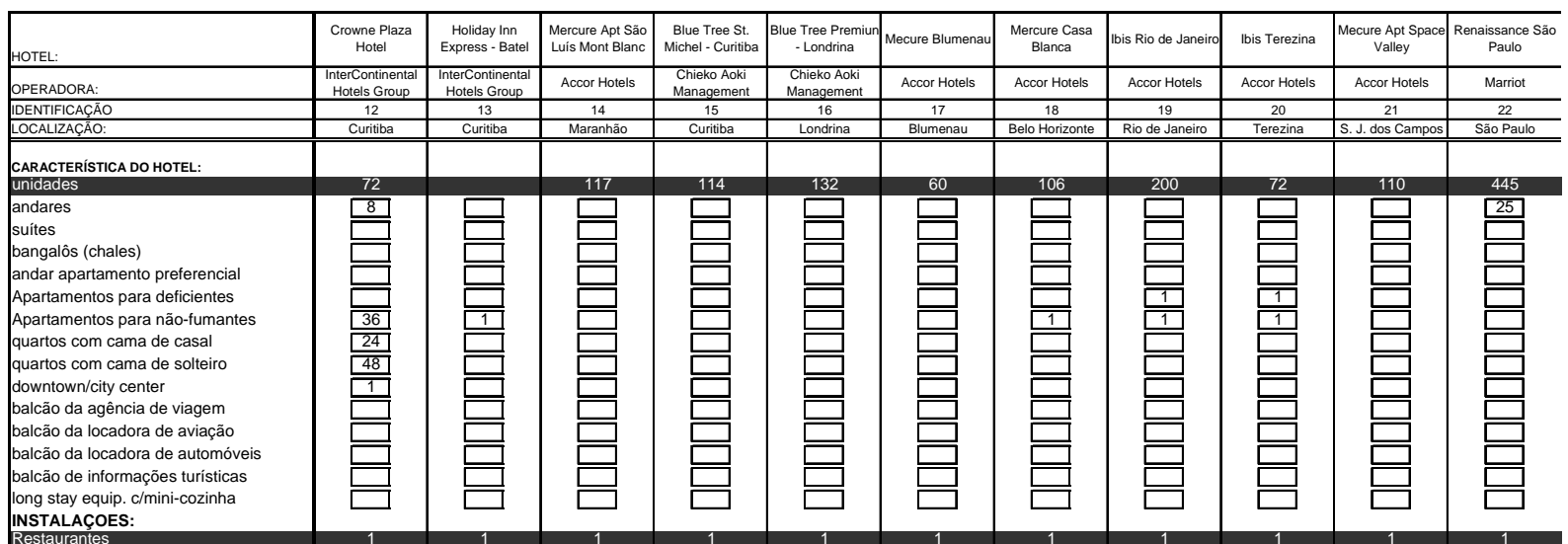

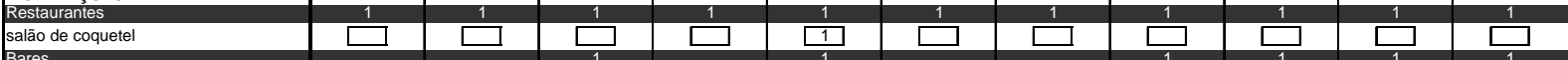

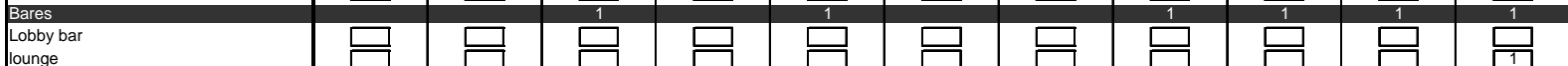
Lobby bar

$\square \quad \frac{5}{1}$ terraço

Recreativo para crianças

Boate

Brinquedoteca

Bluguel de bicicleta

Piscina

Piscina de biriba
Piscina infantil

Parque aquático

Baby copa

Hidromassagem
playground

playground
Heliponto

vista paronâmica

foyer

floricultura

sala de artes

Serviço de baby sitter

Day office

Academia de ginástica

Biblioteca

Home theater

Loja de conveniência

Pista de dança

Sauna
Solárium

Salão de beleza

Salão de be
Boutiques

andares executivo

suites executiva

banca de jornal

Spa
Cyber café

Cyber cafe
Churrasqueira

Kids club com piscina

Bicicleta

Concierge

Futebol socie

Futebol
Anfiteatro

Xadrez gigante

Sala de snooker

Quadra de cooper

spinning e pilates
Quadra de tênis

Quadra de tênis
Quadra de volei de prai

Quadra de volei de praia

Quadra poli-esportiva
Quadra de squash

Quadra de sq

Golfe

Golfe
Rafting

Náutica (windsurf, caiaques...)

Pesca esportiva

Aluguel de lancha, jet sky

Kayaing

Health club

Mini-shopping

Jacuzzi comunitário

Jacuzzi particular
Sala de ping-pong

Sala de ping-po

Sala de jogos

fitness center
Massagem

Massagem
Business cente

sala labrador

Lavanderia

Coffee-shop

ESTACIONAMENTO:
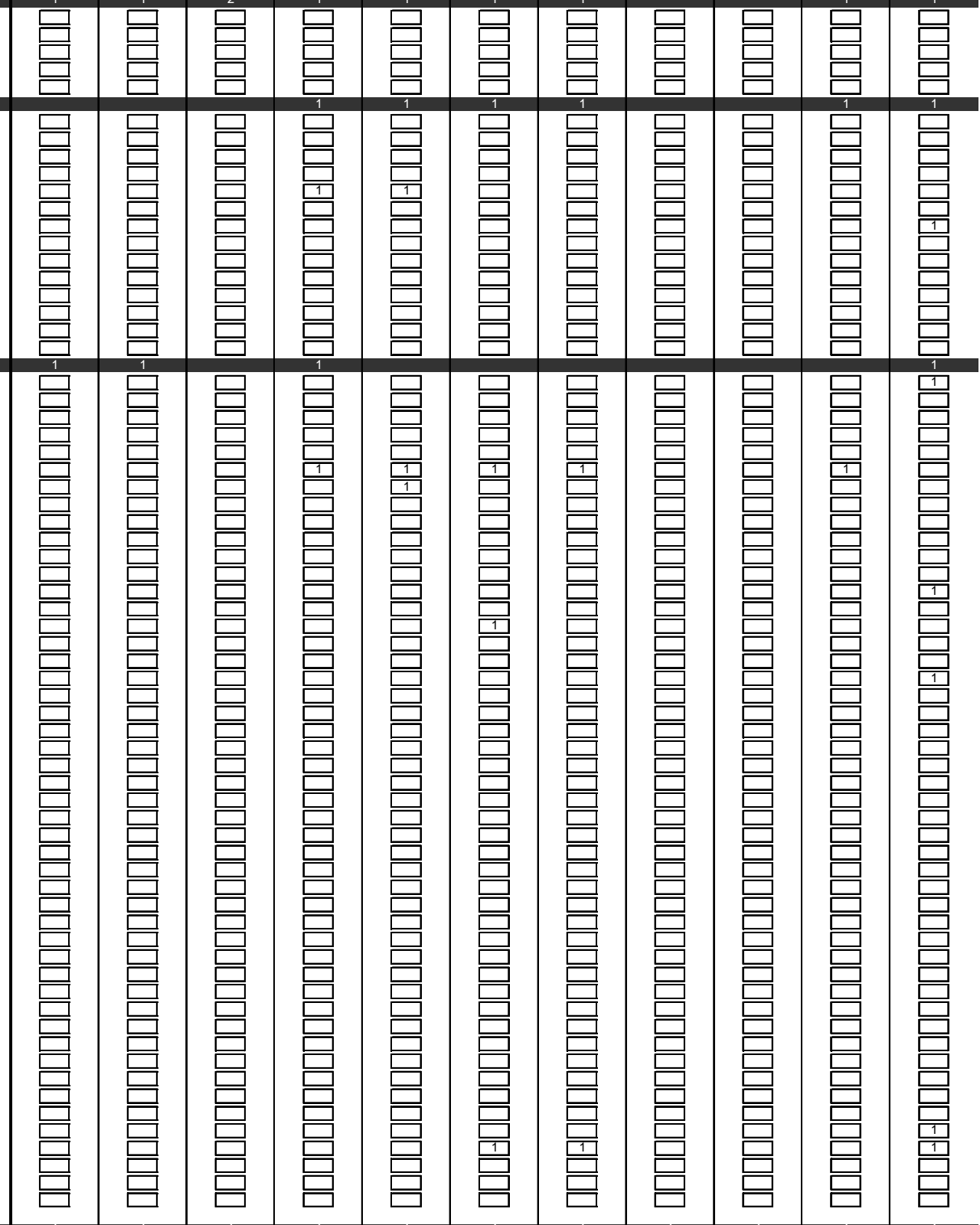

Infra-estrutura dos empreendimentos hoteleiros 


\begin{tabular}{|c|c|c|c|c|c|c|c|c|c|c|c|}
\hline НОТЕ: О: О人 & \begin{tabular}{|c|}
$\begin{array}{l}\text { Inter continental } \\
\text { Hotels \& Resorts }\end{array}$ \\
\end{tabular} & $\begin{array}{l}\text { Caesar Park- } \\
\text { Ipanema }\end{array}$ & $\begin{array}{l}\text { Caesara park. } \\
\text { Guaruluos }\end{array}$ & Sonstat hotel & Sonestat hotel & HT Sáo paulo & 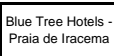 & 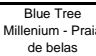 & \begin{tabular}{|l|} 
Sofitel Sâo Paulo \\
\end{tabular} & 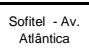 & Soffele Savadator \\
\hline ADORA: & 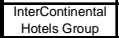 & Caesar Pakt & $\begin{array}{ll}\text { Caesar Patk } \\
\end{array}$ & Sonsta Hools & Sonestat hotels & $\begin{array}{l}\text { Hondelis } \\
\text { Transantica } \\
\end{array}$ & \begin{tabular}{|l|} 
Chiero ank \\
Managament \\
\end{tabular} & 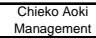 & Accor totels & $\begin{array}{ll}\text { Accor Hotels } \\
\end{array}$ & Accor toutels \\
\hline ITIFCACA & 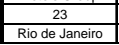 & $\frac{24}{\text { Rio de anairo }}$ & $\frac{25}{\text { SGao paulo }}$ & 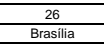 & $\frac{27}{\text { Sio } 7 \text { Paul }}$ & $\begin{array}{ll}28 \\
\text { Sáp paulo }\end{array}$ & $\frac{29}{2 \text { Fotaleza.CE }}$ & 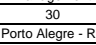 & $\frac{31}{\text { Sắ paulo }}$ & $\frac{32}{\text { Eio do Jan }}$ & $\begin{array}{lll}\text { Baniai } \\
\text { Bant }\end{array}$ \\
\hline \multicolumn{12}{|l|}{ 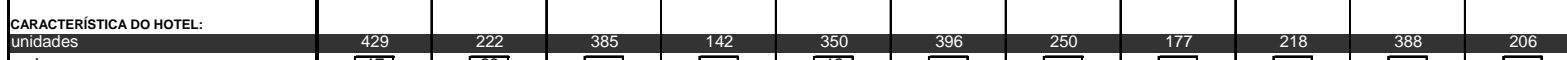 } \\
\hline \begin{tabular}{|l} 
andares \\
sultes
\end{tabular} & $\frac{17}{39}$ & 23 & $\square$ & $\square$ & 18 & $\square$ & $\square$ & $\square$ & $\square$ & $\square$ & $\square$ \\
\hline galos (chales) & D. & 可 & 包 & 㟒 & 亗 & 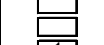 & 包 & 包 & 亗 & 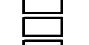 & 亗 \\
\hline 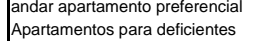 & $\square$ & $\frac{1}{12}$ & $\frac{10}{11}$ & $\square$ & $\square$ & $\frac{1}{\frac{1}{22}}$ & 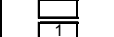 & 19 & $\square$ & $\square$ & $\square$ \\
\hline Aparamentos para näo-tumantes & 62 & 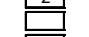 & & 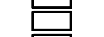 & 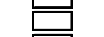 & 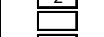 & 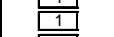 & 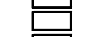 & 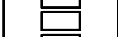 & & 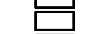 \\
\hline 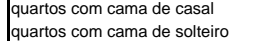 & $\frac{198}{[231}$ & $\square$ & $\square$ & $\square$ & $\square$ & $\square$ & $\square$ & $\square$ & 品 & $\square$ & $\square$ \\
\hline \begin{tabular}{|l} 
downtown/city center \\
balcăo da agencia de viagem
\end{tabular} & $\square$ & $\square$ & $\square$ & $\square$ & $\square$ & $\square$ & $\square$ & $\square$ & 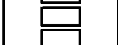 & $\square$ & $\square$ \\
\hline balcāo da locadodra de aviaçăo & " & $\square$ & 0 & 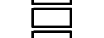 & $\square$ & 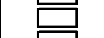 & $\square$ & $\square$ & 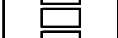 & 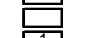 & $\square$ \\
\hline 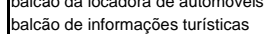 & & & & & 1 & 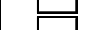 & & & $\square$ & $\frac{1}{81}$ & $\square$ \\
\hline $\begin{array}{l}\text { |long stay equip. Clmini-cozinha } \\
\text { INSTAAACCES: }\end{array}$ & $\square$ & $\square$ & $\square$ & $\square$ & 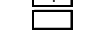 & $\square$ & $\square$ & $\square$ & 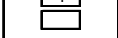 & 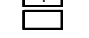 & 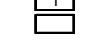 \\
\hline \multirow{2}{*}{\multicolumn{12}{|c|}{ 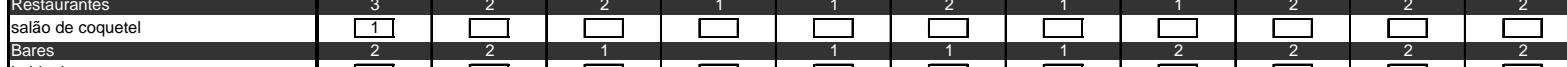 }} \\
\hline & & & & & & & & & & & \\
\hline $\begin{array}{l}\text { loboby bar } \\
\text { lounge }\end{array}$ & $\square$ & 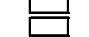 & $\square$ & 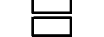 & 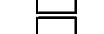 & $\square$ & $\square$ & $\square$ & $\square$ & $\square$ & $\square$ \\
\hline sporte & 1 & 1 & $\square$ & $\square$ & $\square$ & $\square$ & $\square$ & & $\square$ & & \\
\hline 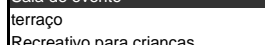 & $\square$ & $\square$ & $\square$ & $\square$ & $\square$ & $\square$ & $\square$ & $\square$ & 10 & 10 & $\square$ \\
\hline Boate & & & & 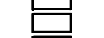 & $\square$ & $\square$ & 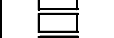 & ב & 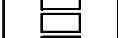 & $=$ & $\square$ \\
\hline $\begin{array}{l}\text { quedoteca } \\
\text { quld bicicteta }\end{array}$ & $\square$ & $\square$ & $\square$ & 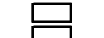 & $\square$ & $\square$ & $\square$ & $\square$ & 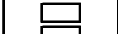 & $\square$ & $\square$ \\
\hline \\
\hline $\begin{array}{l}\text { Piscina de biriball } \\
\text { Piscinin intanti }\end{array}$ & $\square$ & $\square$ & $\square$ & $\square$ & $\square$ & $\square$ & $\square$ & $\square$ & $\square$ & $\square$ & $\square$ \\
\hline $\begin{array}{l}\text { Piscrian ananilu } \\
\text { Parcue aquatico }\end{array}$ & $\square$ & $\square$ & 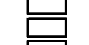 & 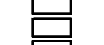 & 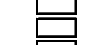 & 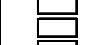 & 1 & ए & ए & $\underline{E}$ & 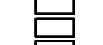 \\
\hline 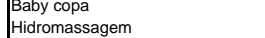 & 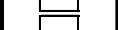 & 可 & 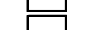 & r & 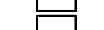 & 7 & & 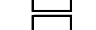 & 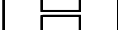 & & \\
\hline playground & 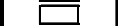 & $\square$ & $\square$ & 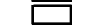 & $\square$ & $\square$ & $\overline{\square 1}$ & ב & $\square$ & $=$ & $\square$ \\
\hline Heliponto & 口 & 只 & $\square$ & 县 & 罗 & 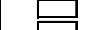 & 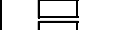 & 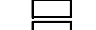 & 1 & $\square$ & 口 \\
\hline $\begin{array}{l}\text { foyer } \\
\text { filociturata }\end{array}$ & 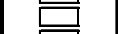 & 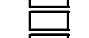 & 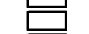 & 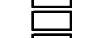 & $\square$ & 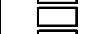 & $\square$ & 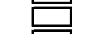 & 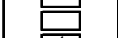 & + & $\square$ \\
\hline 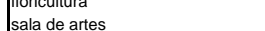 & 남 & 荘 & ب & 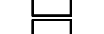 & ب & 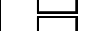 & 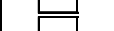 & 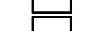 & $\frac{1}{11}$ & 1 & 10 \\
\hline Serviço de baby sitter & $\square$ & $\square$ & $\square$ & $\square$ & $\square$ & $\square$ & $\square$ & $\square$ & 1 & $\frac{1}{11}$ & 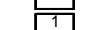 \\
\hline $\begin{array}{l}\text { Servicos de médico } \\
\text { Day ofife }\end{array}$ & $\square$ & $\square$ & $\square$ & $\square$ & $\square$ & $\square$ & $\square$ & $\square$ & 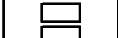 & $\begin{array}{ll}1 \\
\end{array}$ & $\overline{11}$ \\
\hline \multirow{2}{*}{\multicolumn{12}{|c|}{ Servico de Iavanderia }} \\
\hline & $\square$ & $\square$ & $\square$ & $\square$ & $\square$ & $\square$ & $\square$ & $\square$ & $\square$ & 1 & 1 \\
\hline Home theater & $\square$ & $\square$ & $\square$ & 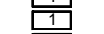 & 1 & $\square$ & 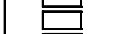 & 0 & 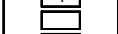 & $\square$ & 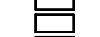 \\
\hline $\begin{array}{l}\text { Pista de danca } \\
\text { Paria }\end{array}$ & 㟧 & 可 & 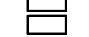 & 1 & $\square$ & 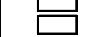 & $\square$ & 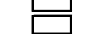 & 1 & 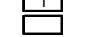 & 11 \\
\hline $\begin{array}{l}\text { Sauna } \\
\text { solarium }\end{array}$ & 1 & $\square$ & 10 & 1 & $\square$ & $\square$ & $\frac{11}{11}$ & 1 & $\square$ & $\square$ & $\square$ \\
\hline Salâo de beleza & 1 & 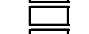 & $\square$ & 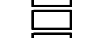 & $\square$ & 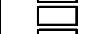 & $\square$ & 0 & 1 & $\square$ & 10 \\
\hline 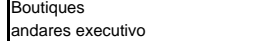 & 1 & 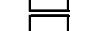 & 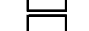 & r & 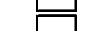 & 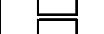 & 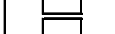 & 7 & " & $\square$ & \begin{tabular}{|l|}
1 \\
\end{tabular} \\
\hline suites executiva & 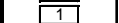 & $\square$ & 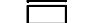 & $\bar{\square}$ & $\square$ & $\square$ & 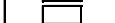 & " & 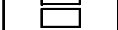 & $=$ & 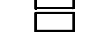 \\
\hline banca de jornal & 10 & $\square$ & $\square$ & $\square$ & $\square$ & $\square$ & $\square$ & 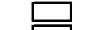 & $\square$ & $=0$ & $\square$ \\
\hline \multirow{3}{*}{$\begin{array}{l}\text { 和ber café́ } \\
\text { Churrasqueira } \\
\text { Kids club com piscina }\end{array}$} & 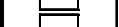 & 然 & 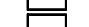 & 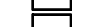 & 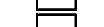 & 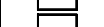 & 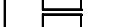 & $=$ & 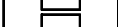 & & $\square$ \\
\hline & 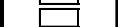 & 更 & 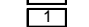 & 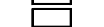 & 更 & $=$ & ק & " & $=$ & 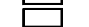 & 4 \\
\hline & $\square$ & $\square$ & & $\square$ & $\square$ & $\square$ & $\square$ & $\sqsupset$ & $\square$ & & $\square$ \\
\hline \multirow{2}{*}{$\begin{array}{l}\text { Concierge } \\
\text { Futeobl society } \\
\text { Futebol }\end{array}$} & 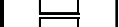 & 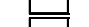 & 1 & 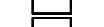 & 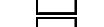 & -1 & 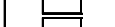 & 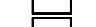 & " & $=$ & $\square$ \\
\hline & 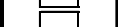 & 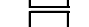 & ק & 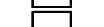 & 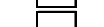 & 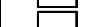 & ק & " & " & 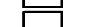 & 宸 \\
\hline \multirow{3}{*}{$\begin{array}{l}\text { Antitiatro } \\
\text { xadrez gigante }\end{array}$} & 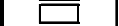 & $\square$ & $\square$ & $\square$ & $\square$ & $\square$ & $\square$ & 己 & $\square$ & & $\square$ \\
\hline & ए & $\square$ & 口 & 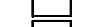 & $\square$ & $\square$ & $\square$ & 马 & 口 & $=$ & $\square$ \\
\hline & 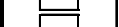 & 贯 & 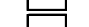 & 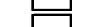 & 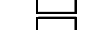 & 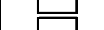 & 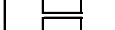 & $=$ & 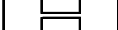 & 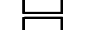 & \\
\hline \multirow{2}{*}{ 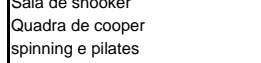 } & 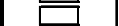 & 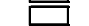 & $\square$ & 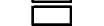 & 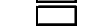 & $\square$ & 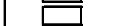 & 至 & $=$ & $x_{-1}$ & 1 \\
\hline & $\sqsubseteq$ & $\square$ & & 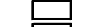 & $\square$ & $\overrightarrow{7}$ & $\square$ & $\square$ & 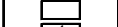 & & \\
\hline \multirow{2}{*}{ 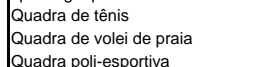 } & L & $\square$ & 1 & 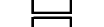 & 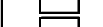 & 2 & 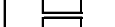 & 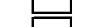 & $1 /$ & 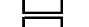 & 10 \\
\hline & 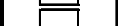 & 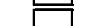 & 1 & 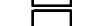 & 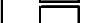 & $=$ & 年 & 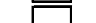 & - & & 1 \\
\hline \multirow{2}{*}{$\begin{array}{l}\text { Quadra de squash } \\
\text { Ecoturismo }\end{array}$} & $\underline{E}+\frac{1}{2}$ & $\square$ & $\square$ & $\square$ & $\square$ & $\square$ & $\square$ & 至 & $\bar{E}$ & 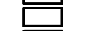 & $\square$ \\
\hline & $=$ & 5 & $\square$ & $\square$ & & & & & & & $\square$ \\
\hline $\begin{array}{l}\text { Ratim } \\
\text { Ratin }\end{array}$ & 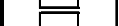 & 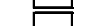 & 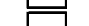 & 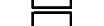 & 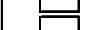 & 1 & 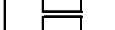 & 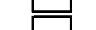 & 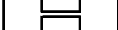 & $=$ & 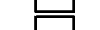 \\
\hline a (windsurt, & 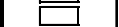 & $\square$ & $\square$ & 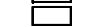 & $\square$ & $\square$ & $\square$ & $\square$ & $=$ & & 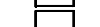 \\
\hline Pesca espotriva & $\square+$ & $\square$ & $\square$ & 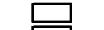 & $\square$ & $\square$ & $\square$ & 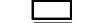 & $\square$ & & $\square$ \\
\hline $\begin{array}{l}\text { and } \\
\text { Kavaing }\end{array}$ & 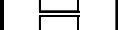 & 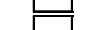 & 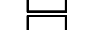 & 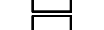 & 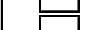 & 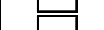 & 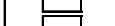 & 要 & 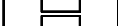 & $=$ & $\square$ \\
\hline Heath clu & & $\square$ & 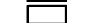 & $=$ & 更 & 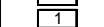 & 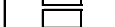 & 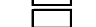 & $=$ & & 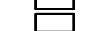 \\
\hline Mini-shopp & E & 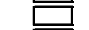 & $=1$ & 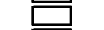 & $\square$ & $=$ & 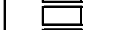 & " & 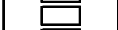 & 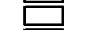 & $\square$ \\
\hline Jacuzzz & $=$ & 宸 & 17 & 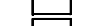 & 11 & 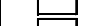 & ب & $=$ & " & & $\square$ \\
\hline sala & 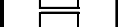 & " & 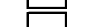 & $\Rightarrow$ & 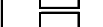 & 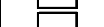 & 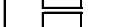 & $\Rightarrow$ & 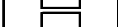 & & 㟧 \\
\hline Sala de & & $\square$ & $\square$ & $=$ & $\square$ & $\bar{\square}$ & $\square$ & & $\square$ & & 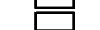 \\
\hline flitiess & $\square$ & 5 & $\square$ & $\square$ & $\square$ & $\square$ & 5 & $\square$ & & & $\square$ \\
\hline Bussignses & 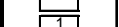 & $\frac{1}{11}$ & 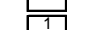 & 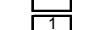 & 5 & 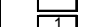 & 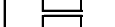 & 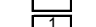 & $=$ & $=$ & $\square$ \\
\hline sala abrador & 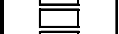 & 表 & 0 & 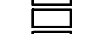 & 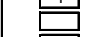 & 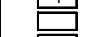 & 0 & 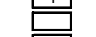 & 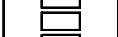 & 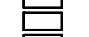 & 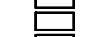 \\
\hline 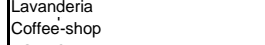 & 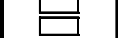 & 㟧 & 际 & 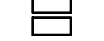 & 맘 & $\square$ & $\square$ & $\square$ & 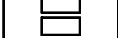 & $\square$ & 㟒 \\
\hline IACIONAM & & & & & & & & & & & \\
\hline
\end{tabular}




\begin{tabular}{|c|c|c|c|c|c|c|c|c|c|}
\hline HОTЕ: & 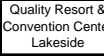 & $\begin{array}{c}\text { Formule 1- } \\
\text { Consolaçá }\end{array}$ & 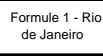 & $\begin{array}{c}\text { Formule } 1- \\
\text { curtiba } \\
\end{array}$ & $\begin{array}{l}\begin{array}{c}\text { Sleep inn } \\
\text { campinas }\end{array} \\
\text { Cans }\end{array}$ & 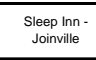 & 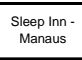 & 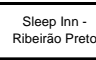 & \begin{tabular}{|c|c|} 
Beach Class \\
Sultes-Recite
\end{tabular} \\
\hline OeERADOPRA: & Atianinica & Accor Hotels & Acocr thoels & Accor Hotels & 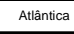 & Altantica & Altaninica & Atannica & $\begin{array}{l}\text { Allaninica } \\
\text { and }\end{array}$ \\
\hline 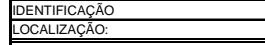 & $\frac{34}{2 \text { Bassia }}$ & $\frac{35}{5 \text { Sao paulo }}$ & $\begin{array}{ll}36 \\
\text { Riod de anatro }\end{array}$ & $\begin{array}{ll}37 \\
\text { Patana } \\
\end{array}$ & $\frac{38}{S \text { sio pauld }}$ & $\begin{array}{ll}39 \\
\text { Santa Cataring }\end{array}$ & $\frac{40}{A \text { amazonas }}$ & $\frac{41}{\text { Sio paulo }}$ & $\begin{array}{ll}42 \\
\text { Penambuco } \\
\end{array}$ \\
\hline \multirow{2}{*}{\multicolumn{10}{|c|}{ 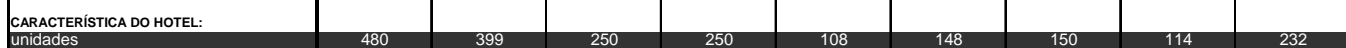 }} \\
\hline & & & & & & & & & \\
\hline $\begin{array}{l}\text { sutes } \\
\text { sutes }\end{array}$ & 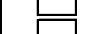 & 날 & 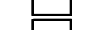 & ب & 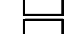 & ب & 남 & ㄹ & $\square$ \\
\hline | bangalâs (chales) & ए & ए & 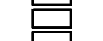 & 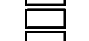 & $\square$ & $\square$ & 要 & 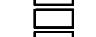 & 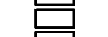 \\
\hline 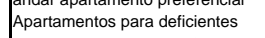 & & 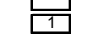 & 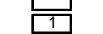 & 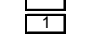 & 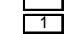 & 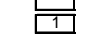 & $\square$ & 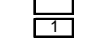 & 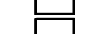 \\
\hline 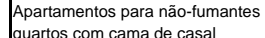 & 10 & $\overline{11}$ & $\overline{11}$ & 11 & $\overline{11}$ & 10 & $\overline{11}$ & 1 & 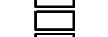 \\
\hline $\begin{array}{l}\text { |quartortom com camana de casal } \\
\text { quaras com cama de solteiro }\end{array}$ & & & & & & $\square$ & & 岸 & \\
\hline 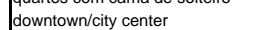 & 焉 & 宸 & 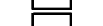 & 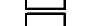 & 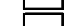 & 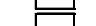 & 更 & 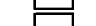 & 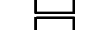 \\
\hline balcăo da agênncia de viagem & 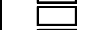 & $\square$ & 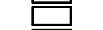 & $\square$ & $\square$ & $\square$ & $\square$ & 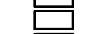 & $\square$ \\
\hline 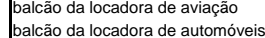 & $\square$ & $\square$ & $\square$ & 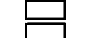 & $\square$ & $\square$ & $\square$ & $\square$ & $\square$ \\
\hline balcão de informaçōes tuŕsisticas & & & & & & 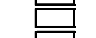 & ב & $=$ & 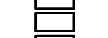 \\
\hline $\begin{array}{l}\text { lolog tsayy equip. climini-cozinha } \\
\text { INSTALACOES: }\end{array}$ & 1 & $\square$ & $\square$ & $\square$ & $\square$ & $\square$ & $\square$ & $\square$ & $\square$ \\
\hline \multicolumn{10}{|l|}{$\begin{array}{l}\text { Restauranies } \\
\text { salâo de coquetel } \\
\text { Bares }\end{array}$} \\
\hline Lobby bar & 1 & $\square$ & $\$$ & $\square$ & 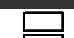 & $\square$ & $\square$ & $\square$ & $\square$ \\
\hline $\begin{array}{l}\text { lounge } \\
\text { Recreatival }\end{array}$ & $\square$ & $\square$ & $\square$ & 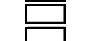 & 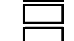 & $\square$ & $\square$ & 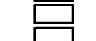 & $\square$ \\
\hline \multicolumn{10}{|l|}{$\begin{array}{l}\text { sala ace venento } \\
\text { teraco }\end{array}$} \\
\hline 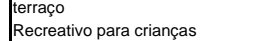 & $\square$ & $\square$ & 品 & $\square$ & $\square$ & $\square$ & $\square$ & $\square$ & $\square$ \\
\hline & & & & & & & $\square$ & & \\
\hline Brinquedoteca & $\square$ & $\square$ & $\square$ & $\square$ & 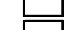 & $\square$ & $\square$ & $\square$ & $\square$ \\
\hline \multicolumn{10}{|l|}{$\begin{array}{l}\text { Piscina a a biriall } \\
\text { Piscina de }\end{array}$} \\
\hline 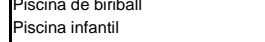 & ㄴ. & 나 & 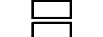 & $\square$ & $\square$ & $\square$ & $\square$ & $\square$ & $\square$ \\
\hline \begin{tabular}{|l} 
Parque aquatico \\
Banky cona
\end{tabular} & $\square$ & $\square$ & 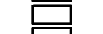 & $\square$ & $\square$ & 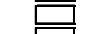 & $\square$ & $\square$ & 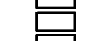 \\
\hline $\begin{array}{l}\text { Hidiromassagem } \\
\end{array}$ & $\square$ & 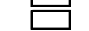 & $\square$ & 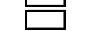 & $\square$ & 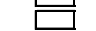 & $\square$ & $\square$ & 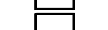 \\
\hline playyround & & & & $\square$ & $\square$ & $\square$ & $\square$ & & $=$ \\
\hline | & ل & 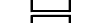 & $\$$ & 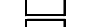 & 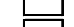 & 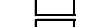 & 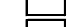 & ل & $\sqsupseteq$ \\
\hline 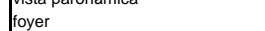 & 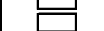 & 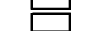 & 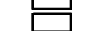 & $\mathrm{L}$ & 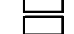 & 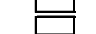 & 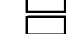 & 並 & 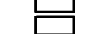 \\
\hline & $\square$ & $\square$ & $\square$ & $\square$ & $\square$ & 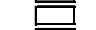 & $\square$ & $=$ & $\square$ \\
\hline | $\begin{array}{l}\text { sala de a ares } \\
\text { cater }\end{array}$ & & & $\square$ & ב & $\square$ & $\square$ & $\square$ & $\square$ & 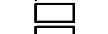 \\
\hline 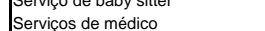 & & $=4$ & 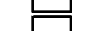 & 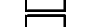 & 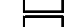 & 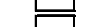 & 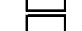 & ل & 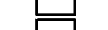 \\
\hline \multicolumn{10}{|l|}{\begin{tabular}{|l} 
Day office \\
Acacalema de ginasicea
\end{tabular}} \\
\hline $\begin{array}{l}\text { Servico de lavanderia } \\
\text { Bibitoca }\end{array}$ & 1 & $\square$ & $\square$ & $\square$ & $\square$ & $\square$ & $\square$ & $\square$ & $\square$ \\
\hline $\begin{array}{l}\text { Biblitocaca } \\
\text { Home theater }\end{array}$ & & 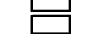 & 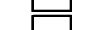 & 㟧 & $-{ }_{1}$ & 步 & 남 & 步 & \\
\hline Loja de conveniencia & 1 & & $\square$ & & & & $\square$ & & 1 \\
\hline Pista de dança & 물 & ए & 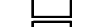 & $\square$ & $\square$ & $\square$ & $\square$ & 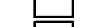 & 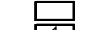 \\
\hline 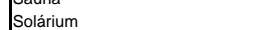 & 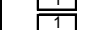 & 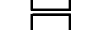 & " & 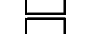 & 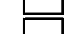 & 남 & 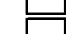 & 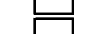 & $\frac{1}{11}$ \\
\hline Salấo de beleza & & 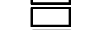 & $\bar{\square}$ & $\square$ & $\square$ & $\square$ & $\square$ & 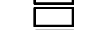 & 1 \\
\hline | Boutiques & $\square$ & $\square$ & $\square$ & $\square$ & $\square$ & $\square$ & $\square$ & & $\square$ \\
\hline $\begin{array}{l}\text { andares executivo } \\
\text { anstive }\end{array}$ & " & 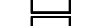 & 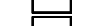 & 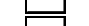 & 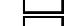 & 4 & $\square$ & " & $\square$ \\
\hline banca de jomal & 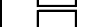 & 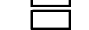 & 背 & (1) & 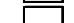 & 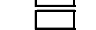 & (ب & 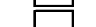 & 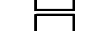 \\
\hline Spa & 10 & & & $\square$ & $\square$ & $\square$ & $\square$ & & \\
\hline Cyber caté́ & 10 & 5 & $\square$ & $\square$ & $\square$ & $\square$ & $\square$ & $\square$ & $\square$ \\
\hline Kids club com piscina & 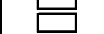 & 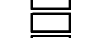 & $\square$ & 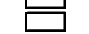 & $\square$ & $\square$ & $\square$ & 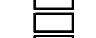 & $\square$ \\
\hline 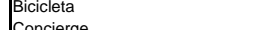 & ב & 5 & ב & ב & 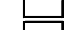 & ב & 口 & $\Longrightarrow$ & $=$ \\
\hline Futebol society & 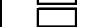 & 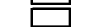 & 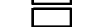 & 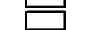 & 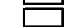 & 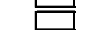 & 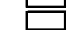 & 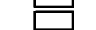 & $\square$ \\
\hline Futebol & $\square$ & $\sqsubseteq$ & $\square$ & $\square$ & $\sqsubseteq$ & $\square$ & $\square$ & E & $=$ \\
\hline 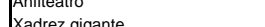 & " & 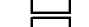 & 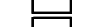 & ل & $=$ & $\square_{10}$ & $\square$ & $=$ & $\square$ \\
\hline Sala de snooker & " & 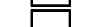 & 背 & 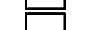 & 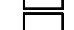 & 宸 & 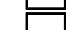 & 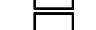 & 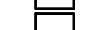 \\
\hline Quadra de cooper & $\square$ & $\square+\square$ & $\square$ & $\square$ & $\square$ & $\square$ & $\square$ & $E$ & $=$ \\
\hline | & 年 & 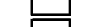 & ب & $\square$ & E & $\square$ & $\square$ & 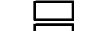 & $=$ \\
\hline puadra de volie de praia & 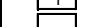 & 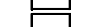 & 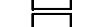 & 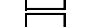 & 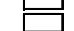 & 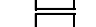 & 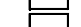 & 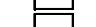 & 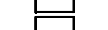 \\
\hline Quadra poli-esportiva & $\sqrt{11}$ & 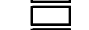 & 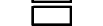 & $\square$ & 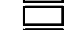 & $\square$ & $\square$ & 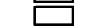 & 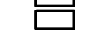 \\
\hline $\begin{array}{l}\text { Quadra de squash } \\
\text { puas }\end{array}$ & & $\sqsubseteq$ & 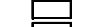 & $\square$ & $\bar{E}$ & $\square$ & $\square$ & $\omega_{-1}$ & 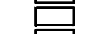 \\
\hline & 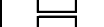 & 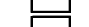 & " & 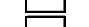 & $=$ & $\square_{10}$ & 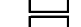 & & $=$ \\
\hline Rating & 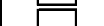 & 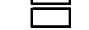 & 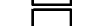 & 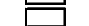 & 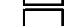 & 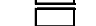 & $\square$ & 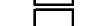 & 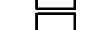 \\
\hline Nautica (windsurf, caiaques...) & 1. & $\square$ & $\square$ & $\square$ & $\square$ & $\square$ & $\square$ & $\square$ & $=$ \\
\hline 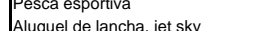 & -4 & 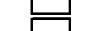 & 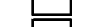 & 1 & $=$ & 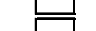 & 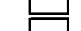 & $=$ & $=$ \\
\hline Kayaing & 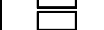 & $=$ & 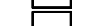 & 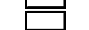 & & 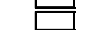 & 年 & $=$ & $=$ \\
\hline Health clu & $\square$ & E & $=$ & $\square$ & 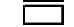 & $\square$ & $\square$ & 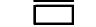 & $=$ \\
\hline |Mini-shopping & $\square$ & 5 & $\square$ & $\square$ & $=$ & $\square$ & $\square$ & $\sqsubseteq$ & 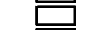 \\
\hline 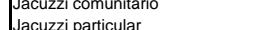 & " & 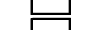 & 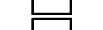 & 正 & 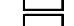 & 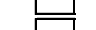 & 4 & $=$ & 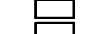 \\
\hline $\begin{array}{l}\text { Sala de ping-pong } \\
\text { S }\end{array}$ & $\square$ & 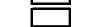 & 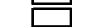 & $\square$ & $=$ & $\square$ & $\square$ & $=4$ & \\
\hline Sala de jog & $\square$ & 5 & $\sqsupseteq$ & $\square$ & 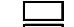 & $=$ & $\square$ & E- & $=$ \\
\hline 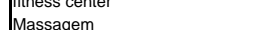 & 1 & & & & & & 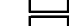 & & \\
\hline Business center & $\frac{1}{\Gamma 1}$ & 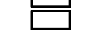 & $=$ & (1) & 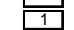 & 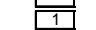 & 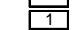 & 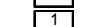 & 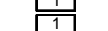 \\
\hline Sala labrador & $\square$ & 5 & & (1 & & & $\square$ & & \\
\hline $\begin{array}{l}\text { Lavandera } \\
\text { colfeishon }\end{array}$ & 11 & Dי & 5 & 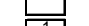 & (1) & \pm & 年 & 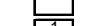 & 1 \\
\hline ACIONAM & & 1 & 1 & 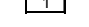 & 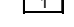 & & & 1 & \\
\hline
\end{tabular}




\section{APÊNDICE 02 - TIPOLOGIA DE EMPREENDIMENTOS HOTELEIROS}

A classificação dos empreendimentos hoteleiros é uma tarefa árdua, devido à diversidade de empreendimentos existentes, com também devido às diferenças as tipologias muitas vezes serem sutis. As diversas classificações existentes são diferenciadas quanto aos atributos a serem analisados.

Wanderley (2004) relata diversas classificações para os empreendimentos hoteleiros, como:

* Classificação quanto ao grau de conforto, qualidade de serviços e preços - superluxo, luxo, superior, turístico, econômico e simples ${ }^{30}$;

* Classificação quanto à localização - hotéis de cidade, de praia, de montanha, hotelfazenda, de aeroporto;

Classificação quanto à destinação - hotéis de lazer, negócios, cassino;

Classificação quanto às diárias oferecidas - upscale, midprice, economy ${ }^{31}$;

Dentre essas classificações, Wanderley (2004) defende a utilização da classificação por meio de diárias médias, devido a sua flexibilidade de adaptação a um determinado mercado, caracterizado em um país ou região.

Nunes (2004) acrescenta outras classificações para hotéis, como:

* Classificação quanto à propriedade - sociedade aberta, sociedade limitada;

* Classificação quanto à rede hoteleira - nacionais, internacionais e independente.

Mattos (2004) relata a classificação dos hotéis resorts quanto a sua localização, como destino praia, neve/montanha, deserto, rio praia, estância hidrotermal, área rural.

\footnotetext{
${ }^{30}$ Classificação realizada pelo Instituto Brasileiro de Turismo (EMBRATUR) e pela Associação Brasileira da Indústria de Hotéis $(\mathrm{ABIH})$, amplamente difundida no Brasil. A EMBRATUR é uma autarquia com a finalidade de auxiliar o Mistério do Turismo no desenvolvimento do turismo brasileiro. A ABIH é um órgão técnico para assuntos referentes ao setor hoteleiro.

${ }^{31}$ Classificação desenvolvida pela American Hotel and Motel Association (AH\&MA) em parceria com a Cornell University.
} 
A classificação quanto ao grau de conforto, qualidade dos serviços e preços reflete o grau de qualidade da estrutura e serviços do empreendimento, contudo nada diz a respeito da diversidade das instalações, número de quartos, a que se destina o empreendimento e sua localização. Já as classificações quanto à localização, destinação, propriedade, porte e rede hoteleira apenas refletem uma característica do empreendimento, escondendo as outras características.

Entretanto, devido à necessidade dessa pesquisa em analisar o ciclo de implantação do empreendimento hoteleiro, a classificação aqui utilizada dever refletir as características físicas dos empreendimentos hoteleiros. Dentre as classificações identificadas, a classificação apresentada por Andrade (2001) ${ }^{32}$ se enquadra às características da pesquisa. A classificação envolve os hotéis centrais, não-centrais, resorts, econômicos.

Cada uma dessas tipologias sofre variação quanto ao padrão do empreendimento, a depender do público a que se destina, contudo em linhas gerais quanto a sua estrutura física não existem grandes alterações.

Essas tipologias serão analisadas a seguir com ênfase nas características de localização e de diversidade das instalações, devido essas características refletirem as condições e os componentes de implantação do empreendimento hoteleiro.

\section{Hotéis Centrais}

São hotéis urbanos localizados em áreas centrais, próximos a restaurantes, bares, comércio, centros de negócios, espaços de lazer, ou seja, áreas com intenso movimento. A localização é um dos principais fatores de atração para os hospedes nessa tipologia de empreendimento.

Os hotéis centrais podem atender a diferentes tipos de público. Existe a possibilidade de serem destinados público de negócio, ou público interessado em compras, ou interessado em turismo, ou mesmo atender simultaneamente todos esses públicos. Essa tipologia de hotel também pode atender a diversos padrões $^{33}$ de clientes. Essa variação do público alvo influencia na qualidade e diversidade das instalações a serem implantadas.

\footnotetext{
${ }^{32}$ Andrade (2001) apresenta diversas tipologias de hotel, contudo, aqui nessa pesquisa serão estudas as tipologias hotel mais encontradas no devido ser objetivo estudar o mercado nacional.

${ }^{33} \mathrm{O}$ padrão do público refere-se à classe social do cliente.
} 
“Os hotéis centrais podem ser grandes ou pequenos (com muitos ou poucos apartamentos), apresentar maior ou menor diversidade de instalações (restaurantes, bares, lojas, salas de reunião, etc.), sem que isso determine maior ou menor possibilidade de sucesso ou fracasso" (ANDRADE, 2005, p.51). Esses hotéis, geralmente, possuem arquitetura vertical, devido à escassez e aos altos preços de terrenos nas regiões centrais.

Com relação aos quartos esses devem possuir as dimensões e mobiliário necessário para atender as exigências do público alvo. Um hotel de negócios deve possuir no quarto uma estrutura para trabalho com iluminação adequada, mesa para trabalho e acesso a internet, por exemplo.

A diversidade de sistemas componentes (ex: quartos, restaurantes, serviços diversos), além de ser influenciada pelas necessidades do público alvo, depende da multiplicidade e qualidades dos serviços oferecidos próximos à região onde o hotel será implantado.

A Figura 14 ilustra a composição das instalações de hotéis centrais no Brasil. É possível concluir que os hotéis centrais, não se apresentam com grande diversidade de instalações para diversão, com exceção de Hotéis como o Renaissance São Paulo, que focam no público de altíssima renda.

Diante dos hotéis apresentados é possível consolidar o conceito que a diversidade de instalações depende do padrão do público alvo, os hotéis centrais com maior diversidade de serviços e instalações são formatados para o público de alta renda. Como também, os hotéis com grande número de instalações possuem muitos apartamentos para sustentar essa estrutura implantada.

Também a partir da Figura 14, juntamente com as informações relatadas anteriormente é possível admitir que a estrutura básica de um hotel central é composta pelos quartos, restaurantes, sala de eventos e estacionamento. Essas são instalações comuns a quase todos os hotéis analisados. 


\begin{tabular}{|c|c|c|c|c|c|c|c|c|c|c|c|c|c|c|c|}
\hline $\begin{array}{l}\text { HOTEL: } \\
\text { LOCALIZACAूO: }\end{array}$ & \begin{tabular}{|c|c|c|c|c|c|} 
Beleme plaza Hote \\
\end{tabular} & $\begin{array}{c}\text { Cromme Plaza Hotele } \\
\text { Curitba }\end{array}$ & 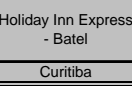 & 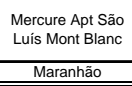 & $\begin{array}{c}\text { Maksoud Plaza } \\
\text { Săo Paulo }\end{array}$ & $\begin{array}{c}\text { Nomanandie Design } \\
\text { Holet } \\
\text { Säo aulo } \\
\end{array}$ & $\begin{array}{l}\text { Pergamon Hotel } \\
\text { Săo Paulo } \\
\end{array}$ & $\begin{array}{l}\text { Bule Tree St } \\
\text { Michel I Curtiba } \\
\text { Curitiba }\end{array}$ & $\begin{array}{c}\text { Bue Tree Premiun } \\
\text { Londrina } \\
\text { Londina }\end{array}$ & \begin{tabular}{|c|} 
Mecure Bumenau \\
Bummenau
\end{tabular} & $\begin{array}{l}\text { Mercure Casa } \\
\text { Blanca } \\
\text { Belo Horizonte }\end{array}$ & \begin{tabular}{|l} 
|isis Rio de Janerio \\
Rio de Janeir
\end{tabular} & \begin{tabular}{|l} 
Ibis Terezina \\
Terezina
\end{tabular} & \begin{tabular}{|l|} 
Mecure Apt Space \\
Valeley
\end{tabular} & $\begin{array}{c}\begin{array}{c}\text { Renaissance São } \\
\text { Pauto } \\
\text { Säo Paulo }\end{array} \\
\end{array}$ \\
\hline \multicolumn{16}{|l|}{$\begin{array}{l}\text { CARACTERISTICA DO HOTEL: } \\
\text { Lnindades }\end{array}$} \\
\hline andares & 17 & 5 & $\square$ & $\square$ & $\square$ & $\square$ & $\square$ & $\square$ & $\square$ & $\square$ & $\square$ & $\square$ & $\square$ & $\square$ & 25 \\
\hline $\begin{array}{l}\text { Aparatamentos ppar deficientes } \\
\text { Aparatanentos para não-fumantes }\end{array}$ & 4 & 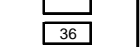 & $+x$ & $\square$ & $\square$ & $\square$ & 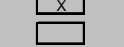 & 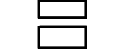 & 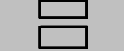 & $\square$ & 鸟 & \begin{tabular}{|l|l}
$x$ \\
$x$
\end{tabular} & $\frac{5 x}{5 x}$ & 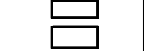 & $\square$ \\
\hline \multicolumn{16}{|l|}{ 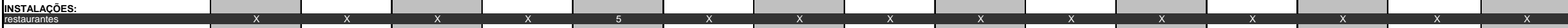 } \\
\hline Salăó de conuetel & $\square$ & $\square$ & $\square$ & $\square$ & $\square$ & $\square$ & $\square$ & $\square$ & $x$ & $\square$ & $\square$ & $\square$ & $\square$ & $\square$ & $\square$ \\
\hline 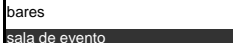 & $\frac{2}{x}$ & $\square$ & $\square$ & 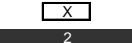 & 5 & $\square$ & एx & $\square$ & $\frac{x}{x}$ & $\square$ & $\square$ & 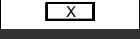 & 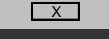 & $x$ & $\frac{x}{x}$ \\
\hline piscina & $x$ & $\square$ & $\square$ & $\square$ & $x$ & $\square$ & $\square$ & $x$ & $x$ & $x$ & $\mathrm{x}$ & $\square$ & $\square$ & $x$ & 然 \\
\hline nhidromassa & $\square$ & 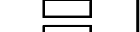 & 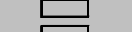 & $\sqrt{2}$ & , & $\square$ & 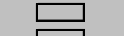 & $x$ & $x$ & 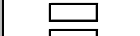 & 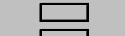 & $\square$ & $\square$ & 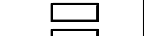 & 7 \\
\hline 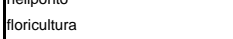 & 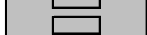 & 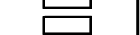 & $\square$ & $\square$ & 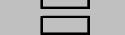 & $\square$ & 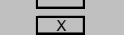 & 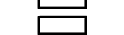 & 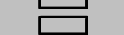 & 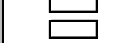 & 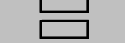 & $\Longrightarrow$ & $\square$ & 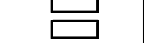 & $x$ \\
\hline Fala de antes & $\square$ & $\square$ & $\square$ & $\square$ & $\square$ & 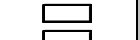 & $\square$ & $\square$ & $\square$ & $\square$ & $\square$ & $\Longrightarrow$ & $\square$ & $\square$ & $\square$ \\
\hline 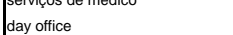 & 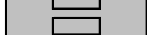 & 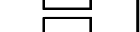 & 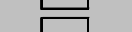 & 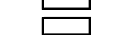 & $\begin{array}{ll}x \\
x\end{array}$ & 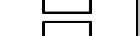 & 5 & 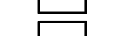 & $\Longrightarrow$ & 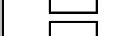 & 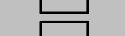 & 7 & $\square$ & 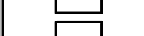 & - \\
\hline academia de ginástica & $\overline{c x}$ & 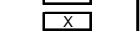 & 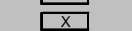 & 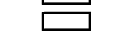 & 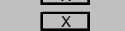 & 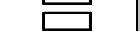 & 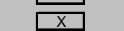 & 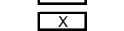 & 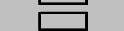 & 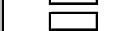 & 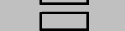 & $\bar{\exists}$ & $\square$ & 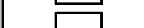 & 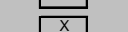 \\
\hline serviço de lavanderia & $\square$ & $\square$ & $\square$ & $\square$ & $\square$ & $\square$ & $\overline{x x}$ & $\square$ & $\square$ & $\square$ & $\square$ & $\sqsupset$ & $\square$ & $\square$ & 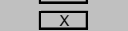 \\
\hline loia de conveniência & $\square$ & $\square$ & $\square$ & $\square$ & $\square$ & $\square$ & $x^{-1}$ & $\square$ & $\square$ & $\square$ & $\square$ & & & $\square$ & 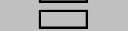 \\
\hline Pista de dança & $\square$ & $\square$ & $\square$ & $\square$ & $\square$ & $\square$ & 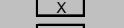 & $\square$ & $\square$ & $\square$ & $\vec{E}$ & 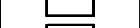 & 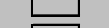 & $\square$ & $\overline{\bar{z}}$ \\
\hline 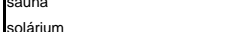 & 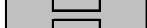 & 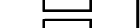 & $\vec{\sigma}$ & 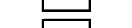 & 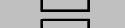 & 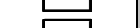 & 4 & $x$ & 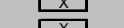 & $x$ & $x$ & & & $x$ & 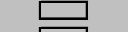 \\
\hline Saläo de belezzat & 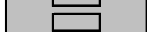 & 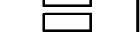 & 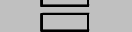 & 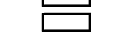 & 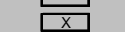 & 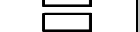 & 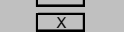 & 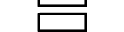 & 宸 & 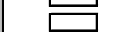 & 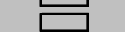 & 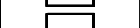 & 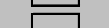 & 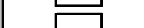 & 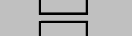 \\
\hline spa & $\square$ & $\square$ & $\square$ & $\square$ & $\square$ & $\square$ & $\square$ & $\square$ & $\square$ & $\square$ & $\square$ & $\square$ & $\square$ & 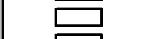 & 5 \\
\hline 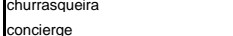 & ب & 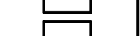 & 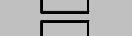 & 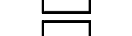 & 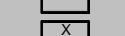 & 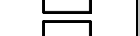 & ب & 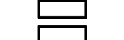 & $\square$ & 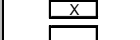 & $\square$ & = & $\square$ & $\square$ & $\overrightarrow{x p}$ \\
\hline leatro & $\square$ & $\square$ & $\square$ & $\square$ & $\mathrm{x}$ & $\square$ & $\square$ & $\square$ & $\square$ & $\square$ & $\square$ & $\square$ & $\square$ & $\square$ & 政 \\
\hline $\begin{array}{l}\text { acuzzzi particular } \\
\text { massagem }\end{array}$ & 4 & 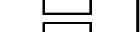 & $\sqrt{2}$ & $=$ & 年 & 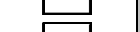 & $\overrightarrow{|c|}$ & 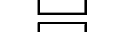 & 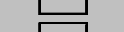 & 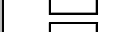 & 4 & 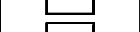 & 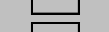 & 4 & $\square$ \\
\hline business center & $\square$ & $\square$ & $\bar{\square}$ & 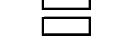 & $\frac{x}{x-1}$ & $\square$ & $x$ & $\square$ & $\square$ & 这 & 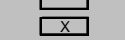 & 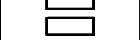 & 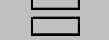 & $\square$ & $x$ \\
\hline
\end{tabular}

Figura 14 - Características Físicas de Hotéis Centrais Fonte: Desenvolvido pela autora (2008) 


\section{Hotéis Não-Centrais}

Os hotéis não-centrais são implantados em regiões com boas condições de acesso. Estão localizados em áreas próximas a centros de negócio, áreas com praia, parque, estações de metrô ou ônibus, ou seja, uma região com os atrativos desejados para o seu público alvo.

Essa tipologia de hotel, geralmente, possui intensa diversidade dos serviços a serem oferecidos como bares, restaurantes, estruturas para esporte e lazer. Em sua maioria, os hotéis não-centrais, por se beneficiarem de terrenos mais baratos que as regiões centrais, possuem grandes áreas de lazer e de estacionamento.

O Hotel Transamérica São Paulo é um exemplo de hotel não central. Mesmo situado na cidade de São Paulo, onde os custos com a aquisição de terreno são elevados, foi possível construir um hotel com campo de golfe e quadras de tênis. Outro exemplo de hotel nãocentral é o Hotel Intercontinental Rio, que mesmo situado na cidade do Rio de Janeiro possui uma grande área de lazer para os hóspedes.

No ciclo de implantação pode existir a necessidade de implantar componentes para os sistemas de abastecimento de água e de eletricidade, como também, componentes do sistema de disposição de esgoto. Isso devido a possibilidade dos hotéis não-centrais ser implantados em regiões ainda em expansão, e não possuir a infra-estrutura necessária.

Para viabilizar toda essa estrutura os hotéis não-centrais, geralmente, possuem um grande número de apartamentos, devido à necessidade de atender ao padrão de resultado econômico almejado. Esse resultado também pode ser atingido com a disponibilização das áreas de lazer para clientes não hospedados no hotel. Essa observação é evidenciada na figura a seguir pois nenhum dos hotéis não-centrais pesquisados apresentam um número inferior a 100 (cem apartamentos).

Similar aos hotéis centrais, o número de instalações depende do púbico alvo almejado. Dentre os hotéis analisados existe uma estrutura básica para os hotéis não centrais composta por quartos, restaurantes, bares, salas de eventos, piscina, academia e estacionamento. 
Com a análise comparativa entre a estrutura básica do hotel central e não-central, o último engloba uma estrutura com maior número de serviços, e conseqüentemente, maior número de quartos. 


\begin{tabular}{|c|c|c|c|c|c|c|c|c|c|c|c|c|c|c|}
\hline \begin{tabular}{|l|} 
HOTEL: \\
LOCALACC \\
\end{tabular} & 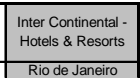 & 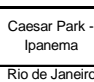 & 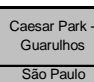 & $\begin{array}{c}\text { Sonestathoul } \\
\text { Brastial }\end{array}$ & 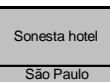 & $\begin{aligned} \text { HT StSo Paulo } \\
\text { Sito Paulo }\end{aligned}$ & 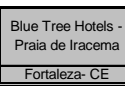 & 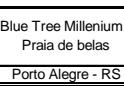 & $\begin{array}{l}\text { Grand thyat } \\
\text { Sa paulo }\end{array}$ & $\begin{array}{c}\text { Soffele Sáo Paulo } \\
\text { Saio Paulo } \\
\end{array}$ & 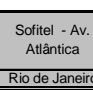 & 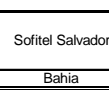 & 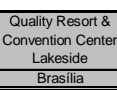 & 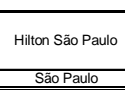 \\
\hline CARACTRESTSTCA DO HOTELL & & & & & & & & & & & & & & \\
\hline 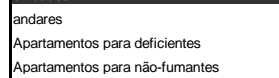 & $\frac{17}{\square .62}$ & $\begin{array}{l}223 \\
2 \\
\end{array}$ & 品 & 可 & 맘 & $\sqrt{2}$ & $\frac{\square}{\square x}$ & 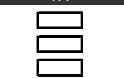 & $\frac{\sqrt{22}}{5 x}$ & $\square$ & 包 & 苛 & $\frac{\square}{\square x}$ & $\begin{array}{l}28 \\
x \\
\square\end{array}$ \\
\hline 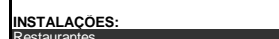 & & & & & & & & & & & & & & \\
\hline 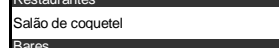 & $\frac{5}{x}$ & $\square$ & $\square$ & 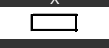 & $\vec{c}$ & $\square$ & $\square$ & $\square$ & $\square$ & $\square$ & $\square$ & 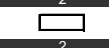 & $\square$ & $\square$ \\
\hline $\begin{array}{l}\text { Lobby bar } \\
\text { lougue } \\
\text { recreatruasesporte }\end{array}$ & 啹 & 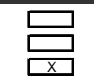 & 品 & 可 & 뭄 & 㞋 & 品 & ק & $\vec{\square}$ & $\bar{Z}$ & 品 & $\vec{\nabla}$ & 要 & 氙 \\
\hline 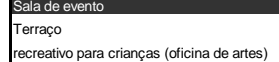 & 可 & 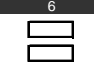 & 마 & 맘 & 맘 & 止 & 밈 & $\not$ & 吅 & x & 㨐 & 品 & 垔 & 맘 \\
\hline 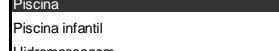 & $\square$ & 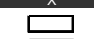 & 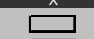 & $\square$ & 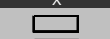 & 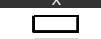 & $x$ & 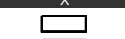 & $\square$ & $\square$ & $\square$ & $\square$ & $x$ & $\square$ \\
\hline $\begin{array}{l}\text { Hidromasasagem } \\
\text { playyrond }\end{array}$ & 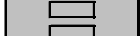 & 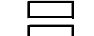 & 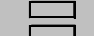 & 마요 & 맘 & 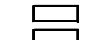 & 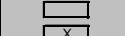 & $\square$ & 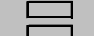 & & $\square$ & $\square$ & 맘 & 啊 \\
\hline Helionomio & $\square$ & $\square$ & $\rightleftarrows$ & Z & ت & $\square$ & 氖 & 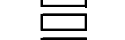 & $\square$ & $x$ & $\square$ & $\square$ & $\square$ & $\square$ \\
\hline $\begin{array}{l}\text { toriciulurar } \\
\text { sala de ares }\end{array}$ & 랄 & $\Rightarrow$ & 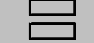 & 可 & 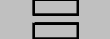 & 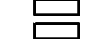 & ए & 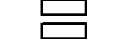 & 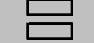 & $\frac{x}{1-x}$ & 骂 & 品 & 可 & 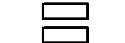 \\
\hline 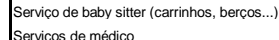 & 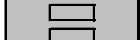 & 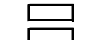 & $\square$ & 말 & $\square$ & $\vec{\square}$ & 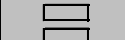 & 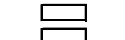 & 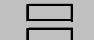 & $x$ & 至 & $x$ & 맘 & $\bar{x}$ \\
\hline 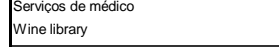 & 际 & 井 & 㟒 & 㟒 & 可 & 㟒 & 包 & 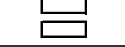 & 2 & 品 & 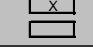 & 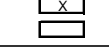 & 㟒 & 宸 \\
\hline 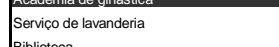 & 弇 & 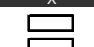 & 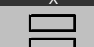 & 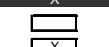 & 랄 & 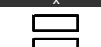 & 맘 & 包 & 包 & 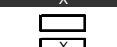 & $\frac{1}{x-2}$ & 第 & 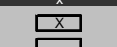 & $\frac{1}{x}$ \\
\hline 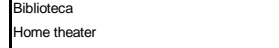 & $\square$ & 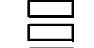 & 焉 & $\frac{x}{\square x}$ & $\square_{x}$ & 昰 & $\square$ & 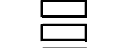 & $\square$ & & 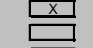 & 医 & 吕 & $\square$ \\
\hline 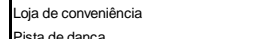 & $\square$ & $\square$ & $\square$ & $x$ & $\square$ & $\square$ & $\square$ & $\square$ & 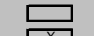 & $\bar{x}$ & $x$ & 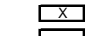 & $x$ & $\square$ \\
\hline sanara & 要 & 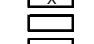 & $x$ & 可 & ह & 尼 & 要 & 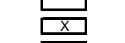 & 然 & 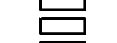 & $\rightleftarrows$ & 可 & 正 & 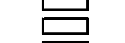 \\
\hline $\begin{array}{l}\text { Solaralum } \\
\text { salá de beleza }\end{array}$ & 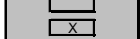 & 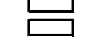 & 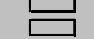 & प & 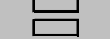 & 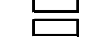 & 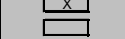 & प्र & 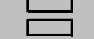 & $\overline{C x}$ & प & 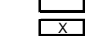 & 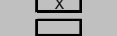 & 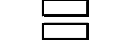 \\
\hline & & $\bar{\square}$ & & & & & & & & $\bar{\square}$ & 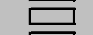 & $\overline{\square x}$ & & x \\
\hline$J^{\text {banna a de irmal }}$ & 品 & $\rightleftharpoons$ & 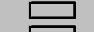 & 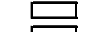 & 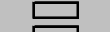 & 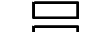 & $\sqsubseteq$ & $\sqsupseteq$ & 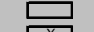 & 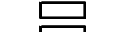 & $\square$ & $\sqsubseteq$ & 品 & \\
\hline ciober ade & 尼 & 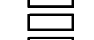 & $\rightleftarrows$ & & 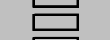 & 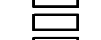 & 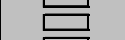 & ह & 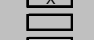 & $\bar{E}$ & 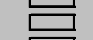 & 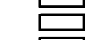 & 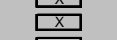 & 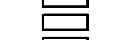 \\
\hline Connierge & 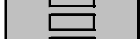 & 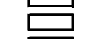 & $\underline{\square}$ & & 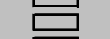 & 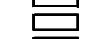 & 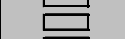 & 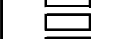 & 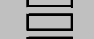 & 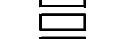 & $\square$ & 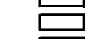 & 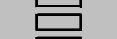 & 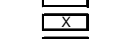 \\
\hline $\begin{array}{l}\text { laeror } \\
\text { eapo center }\end{array}$ & $\square$ & $\square$ & $\square$ & 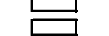 & $\square$ & $\frac{x}{x-x}$ & 맘 & $\square$ & $\square$ & 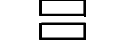 & 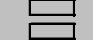 & Б & $x_{1}$ & $\square$ \\
\hline |evarata ac coor & $\square$ & $=$ & 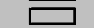 & $\square$ & 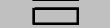 & 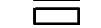 & 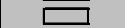 & 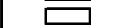 & $\square$ & $=$ & 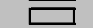 & $\overline{\Gamma x}$ & $=$ & 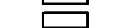 \\
\hline Quadrata de tenis & 骂 & ב & 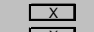 & $\square$ & $\square$ & 2 & $\square$ & $\square$ & $\square$ & 正 & $\sqsubseteq$ & 口, & 品 & 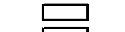 \\
\hline Solle & $x$ & $=$ & 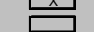 & $\square$ & 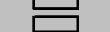 & $x_{x}$ & $\square$ & $\Rightarrow$ & & $\square$ & $=$ & 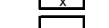 & $\underline{\underline{n}}$ & \\
\hline Natucica (wino & $\square$ & 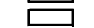 & $\square$ & $\square$ & $\square$ & $\bar{E}$ & 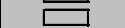 & 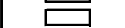 & $\square$ & ᄃ & $E$ & $\square$ & $\overline{E x}$ & \\
\hline Healh oub & $\Longrightarrow$ & $E$ & $\square$ & $\square$ & $\square$ & 5 & $\square$ & $\bar{\square}$ & 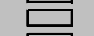 & 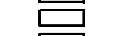 & $\bar{E}$ & $E$ & $\square$ & \\
\hline 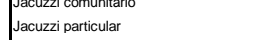 & 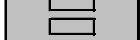 & 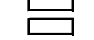 & 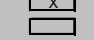 & प्र & 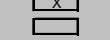 & 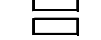 & 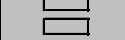 & 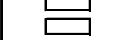 & 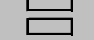 & 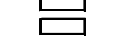 & 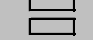 & प्र & 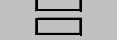 & - \\
\hline & 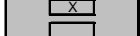 & $\frac{x}{x+2}$ & $\overline{\Gamma x}$ & $x$ & $x^{-1}$ & 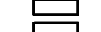 & 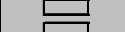 & - & 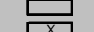 & $\square$ & 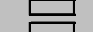 & 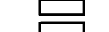 & $\frac{x}{x}$ & \\
\hline 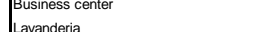 & 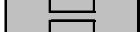 & 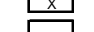 & 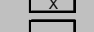 & 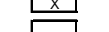 & 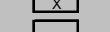 & 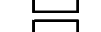 & 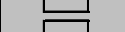 & 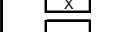 & 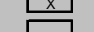 & 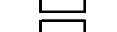 & 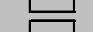 & 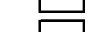 & 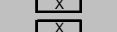 & 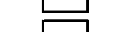 \\
\hline
\end{tabular}

Figura 15 - Características Físicas de Hotéis Não-Central Fonte: Desenvolvido pela autora (2008) 


\section{Resort}

Os Resorts são hotéis de lazer, que possuem como seus maiores atrativos o lazer e descanso dos hospedes, devido aos seus espaços abertos com belezas naturais e áreas de diversão.

Esses são implantados em grandes áreas, comparados a uma ilha auto-suficiente, onde os hospedes encontram satisfação para uma variada gama de interesses (esportes, lazer e vida social), numa combinação que atende a todas as faixas etárias. Por si só esses hotéis são uma destinação turística, como por exemplo, os resorts da Costa de Sauípe, no estado da Bahia.

Essa tipologia de hotel possui grande diversidade de sistemas para atender as necessidades dos usuários. A multiplicidade de sistemas é interessante para atrair hóspedes nas diferentes estações do ano, como também durante a semana e nos finais de semana. Por isso, um resort turístico pode possui centros de conferências e de negócios, como também, diversas áreas de lazer, com a finalidade de diversificar os tipos de hóspedes dispostos a se acomodar nas instalações do hotel.

A implantação pode exigir a instalação da infra-estrutura na área do hotel, como vias de acesso, sistemas de adução de água ou tratamento de esgoto. Conforme as necessidades da região, o investimento pode aumentar. Para dar suporte à necessidade de investimento do resort, esses possuem um grande número de apartamentos.

Conforme a Figura 16, nos resorts existe um grande número de apartamentos, contudo ouve algumas exceções, como o Resort Pestana em Angra dos Reis. Um hotel com apenas 27 acomodações, e toda a estrutura de resort ocorre quando o público alvo é de altíssima renda e está disposto a pagar pela exclusividade dos serviços. Os resorts possuem uma estrutura básica de quartos, restaurante, sala de eventos, piscina, academia, sauna, estrutura de lazer, estacionamento. A estrutura de lazer engloba áreas como quadras, spa, campos de golfe. Essa estrutura de lazer é determinada pelo público alvo e pela disponibilidade da região. 


\begin{tabular}{|c|c|c|c|c|c|c|c|c|c|c|c|c|}
\hline $\begin{array}{l}\text { HOTEL: } \\
\text { OOCAUIZACAO: }\end{array}$ & 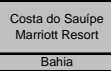 & 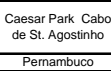 & 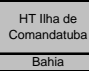 & 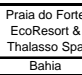 & 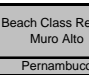 & 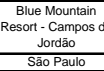 & 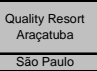 & 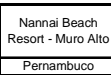 & 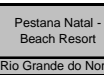 & 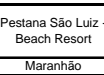 & 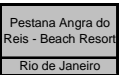 & 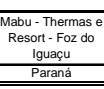 \\
\hline \multicolumn{13}{|l|}{ 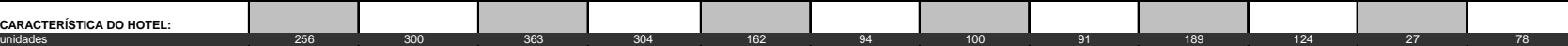 } \\
\hline 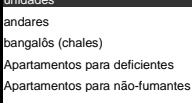 & 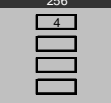 & 苟 & 夏 & 咆 & 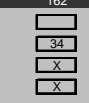 & 营 & 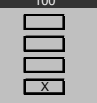 & 鸪 & 哥 & 吕 & 吾 & 吕 \\
\hline \multicolumn{13}{|l|}{ 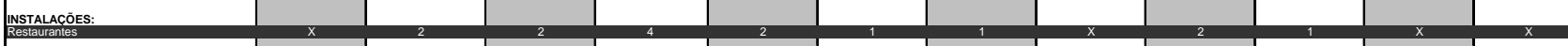 } \\
\hline obbyy bar & $\square$ & $\square$ & $\square$ & $\nabla$ & $x$ & 苛 & $x$ & $\vec{\square}$ & 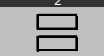 & 号 & $\vec{\nabla}$ & $\vec{\square}$ \\
\hline 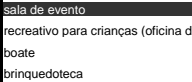 & 믐 & 믐 & 吕 & 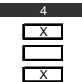 & 要 & 吕 & 啹 & 吕 & $\underline{\underline{z}}$ & 吕 & 吕 & 吕 \\
\hline 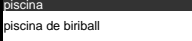 & $\square$ & $x^{x}$ & $\square^{3}$ & $\square$ & $\square$ & $x^{x}$ & $\frac{2}{5 x}$ & $\square^{x}$ & $\square$ & 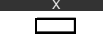 & $\square$ & 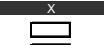 \\
\hline 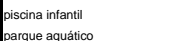 & $\square$ & $\bar{\square}$ & $\bar{\square}$ & $\bar{\nabla}$ & $\square$ & 맘 & 1 & 맘 & $\bar{x}$ & 品 & ק् & $\bar{\square}$ \\
\hline baby copa & Е & 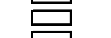 & 豆 & $x$ & $\vec{\nabla}$ & 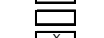 & 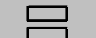 & $\bar{\square}$ & $\equiv$ & 맘 & $\bar{\square}$ & 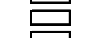 \\
\hline 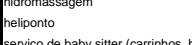 & ह & है & 啹 & $\begin{array}{ll}3 \\
8\end{array}$ & $\frac{x}{5 x}$ & 永 & 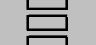 & $\frac{5 x}{5 x}$ & 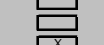 & 崖 & $x$ & 㟒 \\
\hline Senicos de enedico & 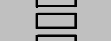 & 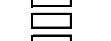 & 号 & 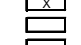 & 리 & 包 & 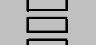 & 蓶 & 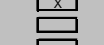 & 电 & 郘 & 包 \\
\hline 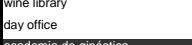 & $\square$ & 맘 & 岂 & $\overrightarrow{7}$ & $\square$ & 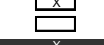 & $x$ & 밈 & $\square$ & 맘 & 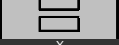 & 岂 \\
\hline 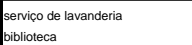 & 맘 & 맘 & 吕 & 吕 & 믐 & 맘 & 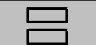 & 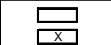 & 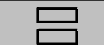 & 맘 & 말 & 밈 \\
\hline 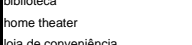 & 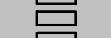 & ק & 号 & ק & है & है & $x$ & 말 & $\rightleftharpoons$ & 券 & ह & 밀 \\
\hline iviar rom & 맘 & 믐 & एव & च & $\not$ & 更 & $\bar{E}$ & 㞋 & $\bar{\nabla}$ & 맘 & ק & 品 \\
\hline 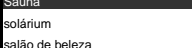 & $\square$ & 品 & 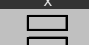 & 民 & $\frac{x}{x}$ & 말 & $x$ & $\square$ & $\vec{F}$ & 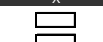 & $\square$ & ק \\
\hline & & & & & & & & & & & & \\
\hline spa & $\bar{x}$ & 产 & 맘 & 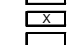 & 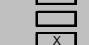 & $\square$ & 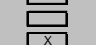 & एव & $\bar{x}$ & $\square$ & $\square$ & 表 \\
\hline 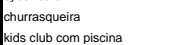 & $\bar{z}$ & 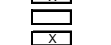 & 要 & 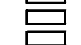 & $\sqrt{E x}$ & 击 & $x$ & 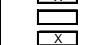 & $=$ & 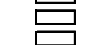 & 年 & 口 \\
\hline $\begin{array}{l}\text { bicicleta } \\
\text { bociege }\end{array}$ & $\bar{\square}$ & 맘 & 맘 & 豆 & 믈 & 맘 & $\bar{\equiv}$ & $\bar{x}$ & $x$ & $\overline{D x}$ & 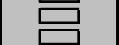 & 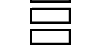 \\
\hline & $\bar{E}$ & 更 & $\square$ & $\bar{E}$ & $x$ & & $x$ & $\square$ & & & & \\
\hline 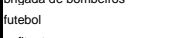 & 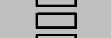 & 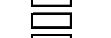 & 2 & 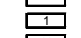 & E & 尼 & $\rightleftharpoons$ & $x$ & 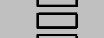 & $x$ & Е & 更 \\
\hline 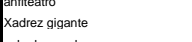 & 랄 & 믈 & 包 & $\begin{array}{ll}x \\
x\end{array}$ & 를 & 品 & $\Xi$ & 말 & 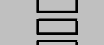 & 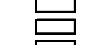 & 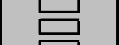 & 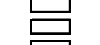 \\
\hline 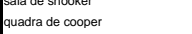 & 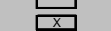 & 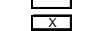 & 남 & 西 & 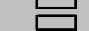 & $\vec{\square}$ & 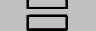 & 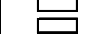 & - & 5 & & \\
\hline Wuatata a elenis & $\bar{x}$ & 4 & 7 & 54 & $\overline{22}$ & $\bar{\square}$ & $\bar{x}$ & $\bar{x}$ & $\bar{E}$ & $\bar{x}$ & $\square$ & $\bar{x}$ \\
\hline 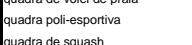 & $\bar{\square}$ & 2 & 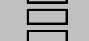 & 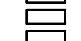 & $\bar{E}$ & 3 & $\bar{x}$ & 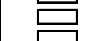 & $x$ & 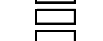 & 要 & 5 \\
\hline 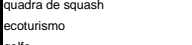 & 단 & $x_{1}$ & 듬 & 这 & 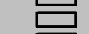 & 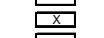 & $x$ & ह & " & $\square$ & $\bar{\nabla}$ & 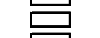 \\
\hline $\begin{array}{l}\text { late } \\
\text { ataing } \\
\text { ang }\end{array}$ & $x$ & 岸 & 骂 & 吕 & 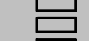 & 믈 & $\equiv$ & 믈 & $\equiv$ & 믈 & 䓃 & 믈 \\
\hline 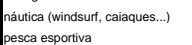 & 丝 & 要 & 品 & 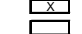 & 맘 & 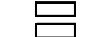 & $\frac{x}{1-x}$ & 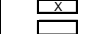 & $\square$ & 孚 & 口 & $\square$ \\
\hline 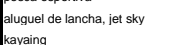 & $\sqrt{x}$ & 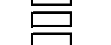 & ק & 豆 & 맘 & 要 & $\bar{x}$ & 口 & 항 & 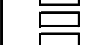 & ק & 듬 \\
\hline 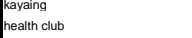 & 西 & 口 & $\square$ & $\bar{\sigma}$ & 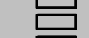 & 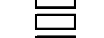 & 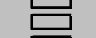 & 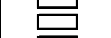 & $\equiv$ & 局 & 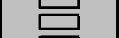 & $\square$ \\
\hline 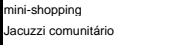 & $\square$ & 鸟 & 吕 & $\frac{x}{\square x}$ & $\sqrt{\square 2}$ & 品 & $\square$ & 吕 & $\bar{x}$ & 品 & 寻 & 豆 \\
\hline |acuzzizi paricicular & ᄃ. & $\bar{E}$ & 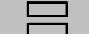 & $x$ & 口 & 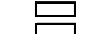 & & 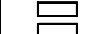 & $\square$ & & $x$ & $\square$ \\
\hline & 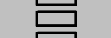 & 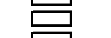 & 들 & $\frac{1}{x}$ & 5 & $\underline{\underline{x}}$ & $\sqrt{x}$ & $\bar{n}$ & EE & 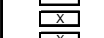 & $\mathrm{x}$ & $\underline{\underline{x}}$ \\
\hline $\begin{array}{l}\text { massastem } \\
\text { ousinas s cont }\end{array}$ & 맘 & 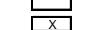 & 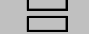 & 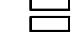 & $\sqrt{x}$ & $\sqrt{x}$ & $\sqrt{x}$ & 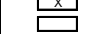 & $\frac{x}{x-x}$ & , & 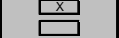 & 5 \\
\hline $\begin{array}{l}\text { Doard room } \\
\text { avanateria }\end{array}$ & $\square$ & $\square$ & 要 & $\square$ & $5 x$ & $\frac{2 x}{x-x}$ & $\sqrt{x}$ & 至 & $\sqrt{x}$ & 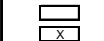 & {$[x$} & 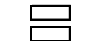 \\
\hline 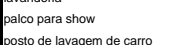 & $\square$ & 맘 & 吕 & 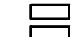 & [x] & 要 & $\sqsubseteq$ & E & $\square$ & 要 & 말 & 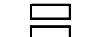 \\
\hline & & & & & & & & & & & & \\
\hline
\end{tabular}

Figura 16 - Características Físicas de Resort

Fonte: Desenvolvido pela autora (2008) 


\section{Hotéis Econômicos}

São hotéis que oferecem os serviços de hospedagem com qualidade à preços baixo, devido a sua estrutura reduzida. Para atender às exigências de qualidade e baixo custo, esses geralmente possuem confortáveis acomodações nos apartamentos, serviços de troca de roupas de cama e banho, limpeza e manutenção das dependências do hotel e restaurante, que em alguns casos podem pode ser reduzido a uma lanchonete.

Essa tipologia de hotel atende ao público que passa pouco tempo nas dependências do hotel, e quer um serviço de qualidade para a sua acomodação.

Geralmente os hotéis econômicos são implantados em regiões de fácil acesso. Quando fora da cidade, esses são implantados próximos a rodovias. Já quando implantado nas cidades, estão localizados próximos à estação de metro ou ônibus, como também em vias de acesso.

As instalações se resumem, de maneira geral, a apartamentos de dimensões e mobiliário adequados, com instalações sanitárias completas e ar condicionado, uma pequena recepção, local para café da manhã e estacionamento, a depender na necessidade dos hóspedes.

Esses podem atender a famílias com a necessidade de camas extras ou beliche e quartos com dimensões maiores. Como também, pode possuir apenas espaço para cama, closet e banheiro. As dimensões reduzidas dos quartos devem ser analisadas na implantação desse empreendimento.

Os hotéis econômicos apresentam uma estrutura básica de quartos, coffee shop e estacionamento. Essa estrutura permite oferecer o conforto desejado, com diária de preço baixo. 


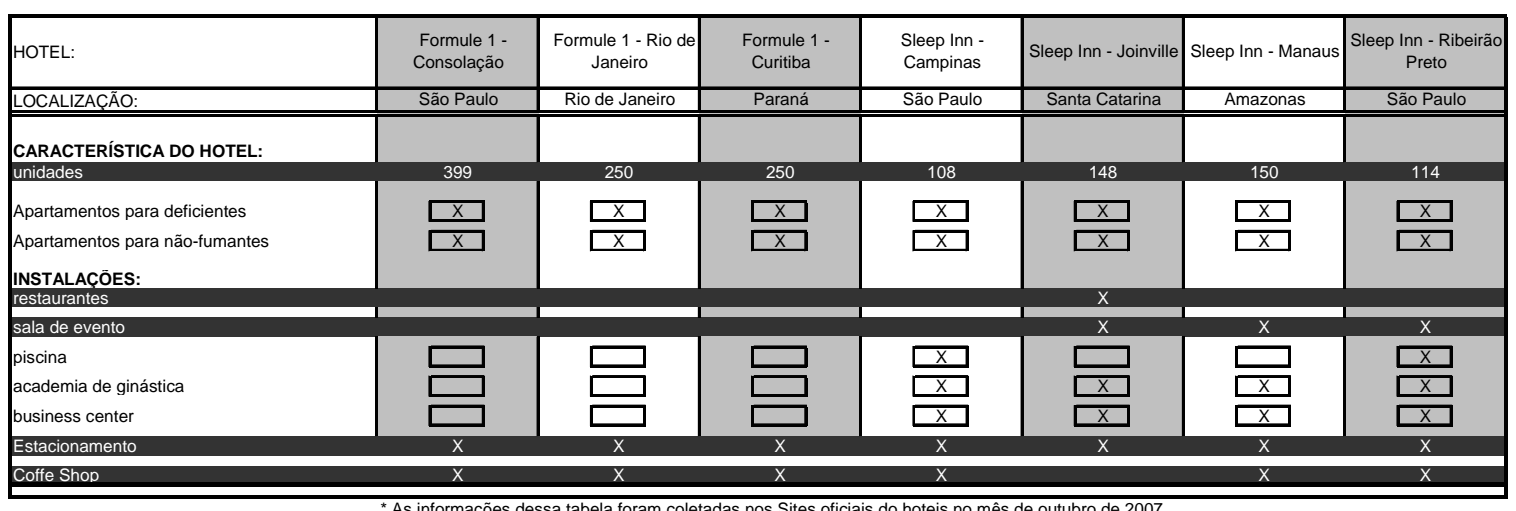

Figura 17 - Características Físicas do Hotel Econômico

Fonte: Desenvolvido pela autora (2008)

\section{ANÁLISE DAS CLASSIFICAÇÕES}

Dentre as tipologias de hotel apresentada segundo a sua estrutura foi possível identificar que existe uma tendência de estruturas básicas, contudo isso não é uma regra. Pois existem hotéis centrais com uma estrutura similar ao hotel não-central, como o Maksoud Plaza e Renaissance. Como também existem hotéis não-centrais com uma estrutura similar aos resorts como o HT São Paulo e Hotel Intercontinental no Rio de Janeiro. O hotel econômico pode ser igual a um hotel central como ocorre com os hotéis Sleep inn. Nesse cenário, é constatada certa complexidade na classificação dos empreendimentos hoteleiros.

Contudo, mesmo com a complexidade das classificações, é possível identificar que a estrutura de um hotel é composta principalmente pela multiplicidade de quartos e por um conjunto de instalações e serviços que complementam as necessidades dos hospedes.

O que diferencia nas estruturas dos hotéis é o nível de qualidade oferecido. Ou seja, todos os hotéis possuem quartos, contudo um hotel de alto padrão possui quartos com infra diversificada. E essa mesma análise vale para os serviços e instalações oferecidas. Contudo todos os hotéis possuem uma área destinada aos quartos e outra destinada aos serviços e instalações oferecidas. 


\section{BIBLIOGRAFIA - APÊNDICE 2}

ANDRADE, Nelson. Hotel: planejamento e projeto. São Paulo: SENAC, 2001. 246p.

MATTOS; Andréa Cilene de. Diretrizes para o Dimensionamento do Número de Unidades Habitacionais de Hotéis Resorts. 2004. 108 f. Dissertação (Mestrado) - Escola Politécnica da Universidade de São Paulo. São Paulo, 2004.

NUNES, Andre Teixeira. Emprego de um Sistema de Informação Geográfica (SIG) para Suporte ao Planejamento do Produto Hoteleiro, Apresentando um Caso para uma Região da Cidade de São Paulo. 2004. 100 f. Dissertação (Mestrado) - Escola Politécnica da Universidade de São Paulo. São Paulo, 2004.

WANDERLEY, Henrique. A Percepção dos Hospedes quanto aos Atributos Oferecidos pelos Hotéis Voltados para o Turismo de Negócios na Cidade de São Paulo. 2004. 98 f. Dissertação (Mestrado) - Escola Politécnica da Universidade de São Paulo. São Paulo, 2004. 


\section{APÊNDICE 03}

PROTOCOLO ESTUDO DE CASO 


\section{APÊNDICE 3 - PROTOCOLO DO ESTUDO DE CASO}

Os hotéis analisados (Capítulo 2 - Empreendimento Hoteleiro, seção 2.2) permitiram reconhecer um padrão de organização para a estrutura oferecida pelos empreendimentos hoteleiros, de acordo com os empreendimentos levantados. Foi possível reunir pontos para auxiliar na definição do escopo da implantação de empreendimentos hoteleiros como a execução da edificação do empreendimento, instalação de mobiliários e equipamentos necessários para a operacionalização do empreendimento.

O corpo de conhecimento adquirido nesse levantamento de campo, juntamente com o conhecimento sobre a implantação de empreendimentos de real estate possibilitou a elaboração de uma primeira hipótese para o escopo de implantação dos empreendimentos hoteleiros capaz de atingir o padrão de organização identificado.

O método para a identificação do escopo de implantação inclui obter primeiramente uma hipótese para o escopo e, em seguida, consolidar esse escopo com profissionais que atuam no mercado na implantação de empreendimentos hoteleiros.

A consolidação da hipótese foi realizada a partir de um estudo de caso. O estudo de caso é um método de pesquisa para a investigação de inferências válidas a partir de eventos que se encontram fora dos limites do laboratório, ao mesmo tempo, em que mantém os objetivos do conhecimento compartilhado com a ciência laboratorial (YIN, 2005).

A consolidação da hipótese não tem como objetivo elaborar um escopo padrão de trabalho aplicável a todos os empreendimentos hoteleiros, mas sim, identificar o conjunto de pacotes de trabalho característico aos empreendimentos hoteleiros abordados como escopo da pesquisa.

Nos parágrafos a seguir está descrita a metodologia de identificação do escopo de implantação dos empreendimentos hoteleiros. 


\section{Objetivo do Estudo de Caso}

O objetivo do estudo de caso é consolidar e complementar, caso seja necessário, a hipótese do escopo de implantação dos empreendimentos hoteleiros.

\section{Instrumento de coleta}

O instrumento de coleta das informações é um questionário semi-estruturado, devido à possibilidade de identificar eventos imprevisíveis, como também direciona a entrevista, sem perder o foco.

O questionário foi aplicado em profissionais envolvidos na implantação de empreendimentos hoteleiros. Houve a premissa de entrevistar profissionais envolvidos nas diversas organizações responsáveis pela implantação do empreendimento, como construtora, grupo investidor e operadora. Essa premissa foi adotada para analisar, caso exista, divergências entre as respostas de cada grupo, como também para coletar as experiências das diversas organizações presente no empreendimento.

A fase inicial do questionário envolveu a identificação do conhecimento e experiência do profissional com a implantação dos empreendimentos hoteleiros, a partir das seguintes questões:

* Cargo atual na empresa;

* Tempo na empresa nesse cargo;

Tempo total de experiência em hotéis;

Formação acadêmica (graduação);

Formação acadêmica (pós-graduação);

Hotéis que trabalhou.

Com a elaboração da hipótese, foi possível ter como premissa inicial que a fase de implantação engloba uma etapa de construção propriamente dita, similar aos 
empreendimentos residenciais, por exemplo, e outra fase de instalação dos equipamentos e móveis necessários para a operação.

O ciclo de implantação é composto por pacotes de trabalho similares aos empreendimentos residenciais, já que um hotel, de maneira similar, possui um grande número de unidades habitacionais em forma de apartamentos ${ }^{34}$. Como também o ciclo de implantação é composto pela fase de instalação dos equipamentos e móveis, característica dos empreendimentos hoteleiros, e pouco é sabido nessa fase da pesquisa como esses pacotes de trabalhos são executados. A primeira hipótese do escopo de implantação dos hotéis está ilustrada na figura a seguir.

E logo em seguida está ilustrado o questionário aplicado.

\footnotetext{
${ }^{34}$ A elaboração da EAP preliminar foi embasada na análise de diversas EAP de empreendimentos residências realizados por uma construtora que atua na cidade de São Paulo. E em seguida, houve o acréscimo das atividades pertencentes exclusivamente aos empreendimentos hoteleiros.
} 


\begin{tabular}{|c|c|}
\hline \multicolumn{2}{|c|}{ 1.0 Serviços de projetos } \\
\hline & Elaboração dos projetos para a execução do empreendimento. \\
\hline \multirow[t]{2}{*}{2.0} & Serviços preliminares \\
\hline & $\begin{array}{l}\text { Serviços de preparação do terreno para a construção do empreendimento, como demolições, } \\
\text { terraplenagem, limpeza de terreno e instalações provisórias. }\end{array}$ \\
\hline \multirow[t]{2}{*}{3.0} & Fundação \\
\hline & $\begin{array}{l}\text { Elementos construtivos como estacas, blocos e lajes, a depender as características do terreno e da } \\
\text { edificação. }\end{array}$ \\
\hline \multirow[t]{2}{*}{4.0} & Estrutura \\
\hline & Elementos construtivos como pilares, vigas, lajes e paredes. \\
\hline & Fechamentos \\
\hline & $\begin{array}{l}\text { Elementos construtivos responsáveis pela vedação dos ambientes, como paredes de alvenaria, } \\
\text { concreto, dry-wall e divisórias. }\end{array}$ \\
\hline & Impermeabilização \\
\hline & $\begin{array}{l}\text { Elementos responsáveis pela impermeabilização das áreas úmidas, como também por isolamentos } \\
\text { acústicos e térmicos. }\end{array}$ \\
\hline & Revestimentos \\
\hline & $\begin{array}{l}\text { Elementos construtivos como chapisco, massa única, emboço, gesso nas paredes e teto, cerâmica, } \\
\text { laminado e pastilha em paredes. }\end{array}$ \\
\hline & Forros \\
\hline & Elementos construtivos de forração do teto. \\
\hline & Piso e Pavimentação \\
\hline & Elementos construtivos de revestimento e estrutura de pisos internos e externos. \\
\hline & Esquadrias e vidros \\
\hline & Elementos construtivos como janelas e portas. \\
\hline \multirow[t]{2}{*}{11.0} & Sistema hidráulico \\
\hline & Sistema relativo ao transporte de águas e esgoto. \\
\hline & Sistema de segurança contra incêndio \\
\hline & Sistema responsável pelo combate ao incêndio. \\
\hline \multirow[t]{2}{*}{13.0} & Sistema elétrico \\
\hline & Sistema responsável pelo fornecimento e descarga de energia. \\
\hline \multirow[t]{2}{*}{14.0} & Sistema de segurança patrimonial \\
\hline & Sistema responsável pela segurança contra furtos e invasão da edificação. \\
\hline \multirow[t]{2}{*}{15.0} & Sistema de transporte \\
\hline & Sistemas construtivos como elevadores e escadas rolantes. \\
\hline \multirow[t]{2}{*}{16.0} & Pintura \\
\hline & Serviço de acabamento nas paredes, teto e pisos. \\
\hline \multirow[t]{2}{*}{17.0} & Cobertura \\
\hline & Elementos construtivos como estrutura da cobertura, telhas, rufos e calhas. \\
\hline \multirow[t]{2}{*}{18.0} & Limpeza geral \\
\hline & Limpeza das áreas do empreendimento. \\
\hline \multirow[t]{2}{*}{19.0} & Sistemas específicos \\
\hline & Sistemas para cozinha, lavanderia, e outros ambientes específico dos serviços oferecidos pelo hotel \\
\hline \multirow[t]{2}{*}{20.0} & Mobiliário \\
\hline & Móveis, elementos decorativos, elementos de cama e mesa, como lençóis e toalhas. \\
\hline \multirow[t]{2}{*}{21.0} & Serviços de partida \\
\hline & $\begin{array}{l}\text { Fase inicial de operação do empreendimento, com todos os serviços planejados à ser oferecido ao } \\
\text { cliente. }\end{array}$ \\
\hline
\end{tabular}

Figura 18 - Hipótese do escopo da implantação de hotéis Fonte: Desenvolvido pela autora (2008) 


\section{ESCOLA POLITÉCNICA DA UNIVERSIDADE DE SÃO PAULO}

DEPARTAMENTO DA CONSTRUÇÃO CIVIL

Núcleo de Ensino e Pesquisa em Real estate

QUESTIONÁRIO ESTUDO DE CASO

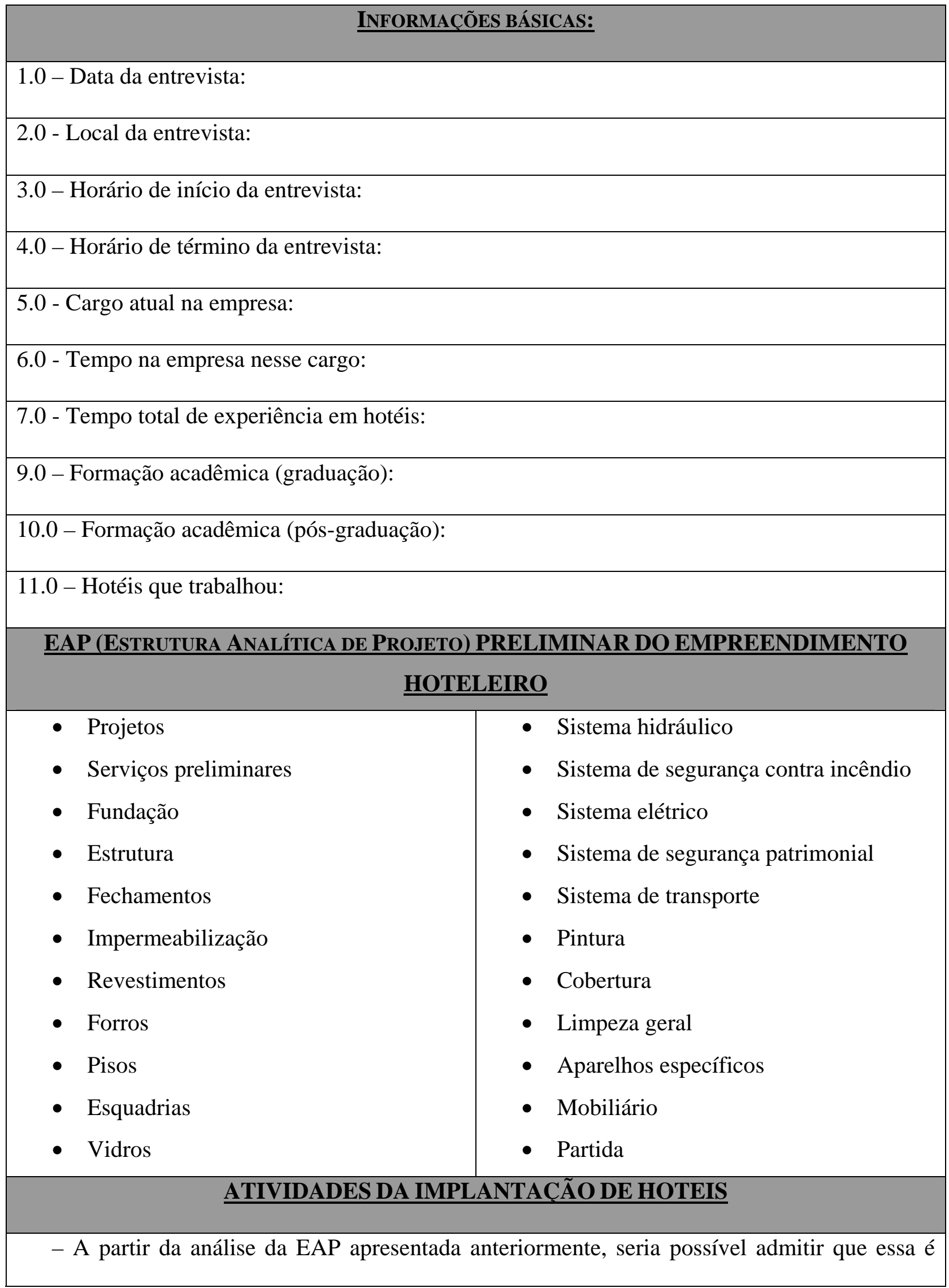




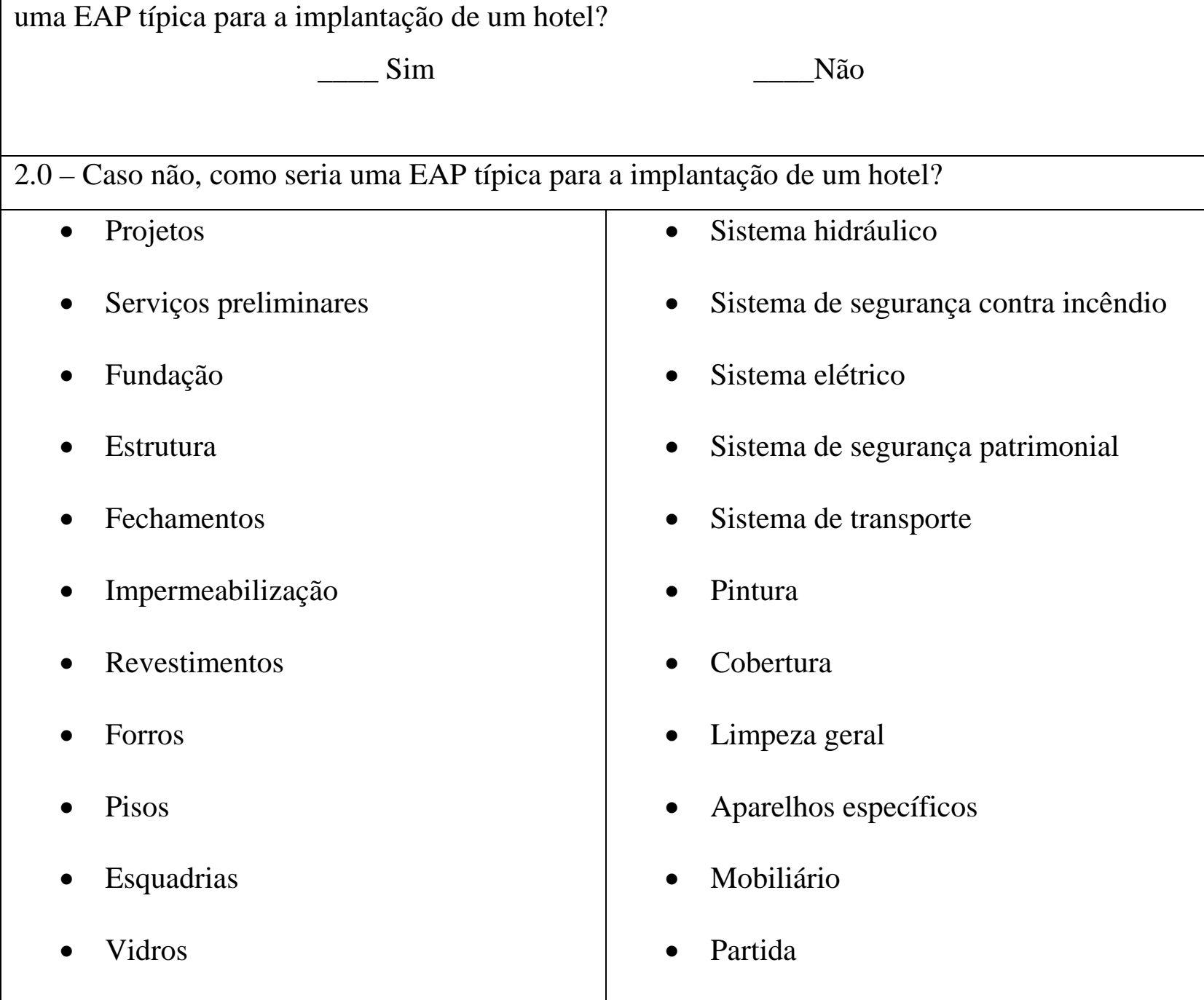




\section{Pré-teste e aferição dos instrumentos de coleta}

Nessa etapa houve a simulação de uma entrevista com profissional na implantação de empreendimentos, com a finalidade de analisar da clareza das questões diante dos seus objetivos ao serem formuladas.

\section{Seleção/escolha do fator gerador (sujeitos, amostra, etc)}

Foram selecionados profissionais que atuam no mercado hoteleiro durante o ciclo de formatação, implantação e operação. Entretanto a amostra de profissionais que atuam no ciclo de implantação foi maior, devido à pesquisa analisar essa etapa do empreendimento.

\section{Desenvolvimento de atividades}

O primeiro contato com os profissionais ocorreu por meio eletrônico. Nesse contato houve o esclarecimento do propósito da pesquisa e solicitação de entrevista. A partir da disponibilização do profissional, houve o agendamento da entrevista. Algumas entrevistas foram gravadas a depender da autorização do entrevistado.

\section{$\underline{\text { Tratamento quantitativo e/ou qualitativo dos dados, na forma de resultados }}$}

As informações coletadas nas entrevistas foram tabuladas de maneira a ser possível realizar a análise comparativa entre as respostas dos entrevistados, com relação ao seu perfil profissional, experiência em hotéis e visão em relação ao ciclo de implantação.

\section{Análise dos resultados, em função dos objetivos}

As respostas obtidas foram tabuladas a seguir. 


\begin{tabular}{|c|c|c|c|c|c|}
\hline & Questões & Entrevistado 1 & Entrevistado 2 & Entrevistado 3 & Entrevistado 4 \\
\hline \multirow{6}{*}{ 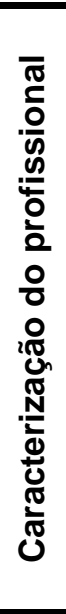 } & Cargo Atual & $\begin{array}{c}\text { Gerente de Manutenção } \\
\text { de Hoteis }\end{array}$ & Investidor & $\begin{array}{c}\text { Gerente Comercial da } \\
\text { Unidade de Negócios - } \\
\text { Hoteis e Hospitais }\end{array}$ & Gerente de Engenharia \\
\hline & Tempo nesse cargo & 2 anos & 3 anos & 6 meses & 9 anos \\
\hline & $\begin{array}{l}\text { Tempo de Experiência com } \\
\text { hoteis }\end{array}$ & 2 anos & 3 anos & 7 anos & 8 anos \\
\hline & Formação Acadêmica & Eng. Elétrico & Adminstrador & Eng. Civil & Eng. Civil \\
\hline & |Pós-Graduação & - & - & $\begin{array}{l}\text { Engenharia de produção } \\
\text { para engenheiros civis } \\
\text { (Fundação Vazoline) }\end{array}$ & $\begin{array}{c}\text { Gerenciamento de } \\
\text { Empreendimentos (USP), } \\
\text { Administração de } \\
\text { empresas (FGV) } \\
\end{array}$ \\
\hline & Hoteis que trabalhou & Rede Hoteleira (1) & $\begin{array}{l}\text { Resorts localizados no } \\
\text { Nordeste (Brasil) (1) }\end{array}$ & $\begin{array}{c}\text { Hotel Unique (São Paulo) } \\
\text { e Ecoresort Ponta do } \\
\text { Mosqueiro (Sergipe) } \\
\end{array}$ & $\begin{array}{l}\text { Rede Accor - Hoteis Ibis, } \\
\text { Mercure, Formule } 1\end{array}$ \\
\hline $\begin{array}{l}\frac{\pi}{2} \\
0 \\
0\end{array}$ & $\begin{array}{l}\text { A WBS preliminar é tipica de } \\
\text { um empreendimento hoteleiro }\end{array}$ & Sim & Não & Não & Não \\
\hline 莺 & $\begin{array}{l}\text { Quais atividades foram } \\
\text { excluidas da WBS preliminar }\end{array}$ & - & - & - & - \\
\hline 造 & $\begin{array}{l}\text { Quais atividades foram } \\
\text { acrescentadas da WBS } \\
\text { preliminar }\end{array}$ & - & Paisagismo & $\begin{array}{c}\text { Sistemas de ar } \\
\text { condicionado e paisagismo }\end{array}$ & Sistema de automação \\
\hline
\end{tabular}

(1) Esses profissionais solicitaram não relatar os hoteis e operadora que trabalham ou trabalharam

Figura 19 - Tabulação das Entrevistas do Estudo de Caso Fonte: Desenvolvido pela autora (2008) 
* Apenas um entrevistado afirma que a EAP preliminar ser a EAP típica dos empreendimentos hoteleiros;

Nenhuma das atividades da EAP preliminar foi excluída;

Dois entrevistados apontaram o paisagismo como uma atividade a ser acrescida na EAP;

* Dois entrevistados apontaram o sistema de condicionamento de ar como uma atividade a ser acrescida na EAP;

Dois entrevistados apontaram o sistema de automação como uma atividade a ser acrescida na EAP;

Todos os entrevistados afirmam a EAP modificada é uma EAP típica para as tipologias de hotel.

Diante da estruturação das informações duas conclusões principais podem ser obtidas. A primeira é que a EAP preliminar está muito próxima da EAP dos empreendimentos hoteleiros, pois nenhuns dos entrevistados excluíram atividades e acrescentam poucas atividades. A segunda conclusão é que existe uma EAP típica para as tipologias de hotel.

As atividades de paisagismo, sistema de condicionamento de ar e sistema de automação, atividades citadas pelos entrevistados, foram analisadas para ser inserida na EAP típica.

A atividade paisagismo, conforme o quadro com a infra-estrutura dos hotéis, está presente principalmente nos hotéis com grandes áreas livres para diversão. Como também está presente nos hotéis em forma de decoração dos ambientes. E com isso essa atividade foi inserida na EAP típica dos empreendimentos hoteleiros.

A atividade sistema de condicionamento de ar está presente nos hotéis, no sentido que conforto é a exigência básica dos hóspedes. Mesmo nos hotéis com estrutura reduzida, a presença de sistema de ar condicionado é fundamental. Os hotéis da bandeira Formule 1, que são considerados hotéis super-econômicos, possuem esse sistema. Hoje é inconcebível pensar em construir um hotel sem um sistema de condicionamento de ar. 
Um sistema de automação proporciona maior agilidade nas operações, redução de custos operacionais e aumento do conforto. As informações possíveis de serem gerenciadas pelo sistema de informação dependem dos recursos disponíveis para a implantação e do padrão do hotel. Como os hotéis desejam a redução dos custos operacionais, cada vez mais os sistemas automatizados são implantados.

Em conseqüência, as atividades de paisagismo, sistema de condicionamento de ar e sistema de automação foram inseridas na EAP típica dos empreendimentos hoteleiros. A EAP típica do empreendimento hoteleiro é ilustrada a seguir.

\section{Relatório}

A apresentação dos resultados desse levantamento de campo está estruturada no capítulo Empreendimento Hoteleiro, seção 2.3. 